\title{
O CONTRATO FUTURO DE BOI GORDO: UMA ÁNÁLISE DO IMPACTO DA INTRODUÇÃO DA LIQUIDAÇÃO FINANCEIRA SOBRE O RISCO DE BASE
}

THEREZA CHRISTINA PIPPA ROCHELLE

Engenheiro Agrônomo

Orientador: Prof. Dr. Joaquim Bento de Souza Ferreira Filho

\begin{abstract}
Dissertação apresentada à Escola Superior de Agricultura "Luiz de Queiroz", Universidade de São Paulo, para obtenção do título de Mestre em Ciências, Área de Concentração: Economia Aplicada.
\end{abstract}

PIRACICABA

Estado de São Paulo - Brasil

Julho de 1997 
Dados Internacionais de Catalogação na Publicação (CIP) DIVISÃO DE BIBLIOTECA E DOCUMENTAÇÃO - Campus "Luiz de Queiroz"/USP

Rochelle, Thereza Christina Pippa

- O contrato futuro de boi gordo : uma análise do impacto da introdução da liquidaçăo financeira sobre o risco de base / Thereza Christina Pippa Rochelle. - Piracicaba, 1997.

$140 \mathrm{p}$.

Dissertaçāo (mestrado) - - Escola Superior de Agricultura Luiz de Queiroz, 1997. Bibliografia.

1. Bovino de corte 2. Economia agricola 3. Mercado futuro I. Titulo

CDD 338.176213 


\section{O CONTRATO FUTURO DE BOI GORDO: UMA ANÁLISE DO IMPACTO DA INTRODUÇÃO DA LIQUIDAÇÃO FINANCEIRA SOBRE O RISCO DE BASE}

THEREZA CHRISTINA PIPPA ROCHELLE

Aprovada em: 11.09.1997

Comissão julgadora:

Prof. Dr. Joaquim Bento de Souza Ferreira Filho

ESALQ/USP

Prof. Dr. Geraldo Sant'ana de Camargo Barros

ESALQ/USP

Dr. Oscar Frick

$B M \& F$

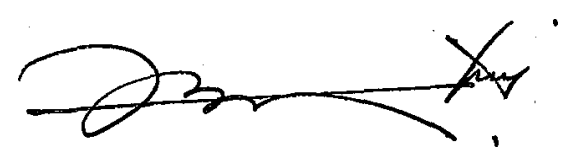

Prof. JOAQUIM BENTO DE SOUZA FERREIRA FILHO Orientador 
Aos meus pais, Edson e Maria Therezinha, pela incansável

dedicação e exemplo de amor e união. 


\section{Agradecimentos}

Ao Professor Doutor Joaquim Bento de Souza Ferreira Filho, pela orientação segura, apoio e incentivo constantes durante a elaboração deste estudo.

Ao corpo docente do Departamento de Economia e Sociologia Rural da Escola Superior de Agricultura "Luiz de Queiroz" (DESR/ESALQ), pelos preciosos ensinamentos adquiridos durante o Curso de Mestrado.

Ao Professor Geraldo Sant'ana de Camargo Barros e à Dra. Miriam Rumenos Piedade Bacchi, pela participação e valiosas sugestões, que muito contribuiram para o aperfeiçoamento deste trabalho.

À Bolsa de Mercadorias \& Futuros (BM\&F), na pessoa do Doutor Oscar Frick, pela participação e solicitude nos esclarecimentos sobre aspectos operacionais do mercado futuro de commodities agropecuárias, que muito auxiliaram na condução desta pesquisa.

Ao Centro de Estudos Avançados em Economia Aplicada da Fundação de Estudos Agrários "Luiz de Queiroz" (CEPEA/FEALQ), na pessoa do pesquisador Sérgio De Zen e ao Instituto de Economia Agrícola (IEA), através da pesquisadora Maura Maria Demétrio, pela atenção no fornecimento dos dados utilizados neste estudo. 
Aos Professores Rodolfo Hoffmann e Ana Lúcia Kassouf, do DESR/ESALQ, ao Professor Carlos Tadeu dos Santos Dias, do Departamento de Matemática e Estatística da Escola Superior de Agricultura "Luiz de Queiroz" (DME/ESALQ) e também ao Sr. Marcelo Corrêa Alves, do Centro de Informática na Agricultura (CIAGRI), pelas importantes contribuições referentes às partes estatística e econométrica desta dissertação.

Ao Professor Raymond M. Leuthold, da Universidade de Illinois, pelo incentivo, atenção e significativos esclarecimentos conceituais, fundamentais para a condução desta pesquisa.

À Rosa Maria Silveira Sigrist e Fábio Zanini pelo auxilio na obtenção de parte do material bibliográfico, que muito auxiliaram na elaboração deste trabalho.

À Professora Maria Helena Varella Bruna, pela dedicada e cuidadosa revisão do texto desta dissertação.

Aos funcionários do DESR, pela atenção e cooperação durante todo o Curso de Mestrado.

À CAPES pela Bolsa de Estudos concedida durante o Curso de Mestrado.

Aos colegas do Curso de Mestrado e a todas as demais pessoas que, direta ou indiretamente, contribuíram para a realização deste trabalho. 


\section{SUMÁRIO}

Página

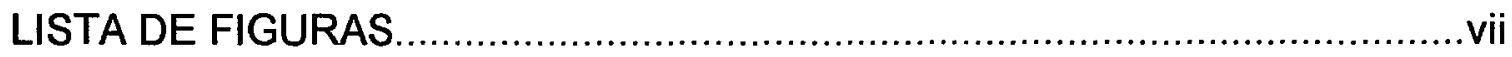

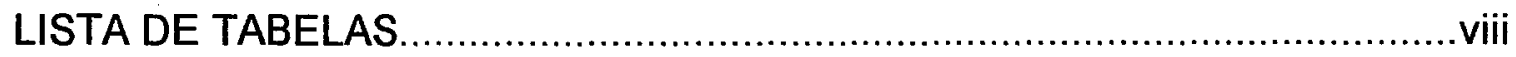

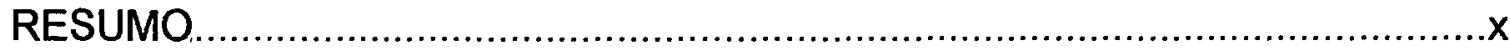

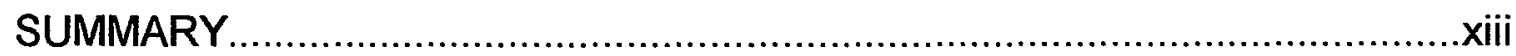

1. INTRODUÇÃO

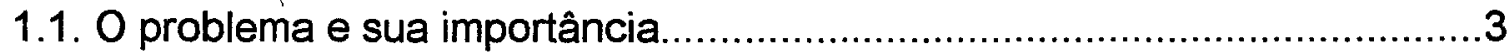

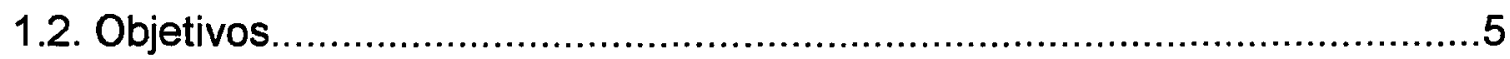

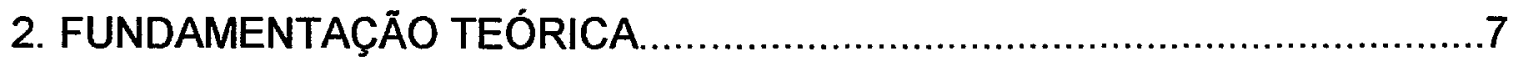

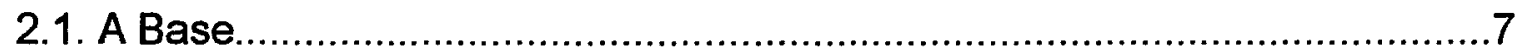

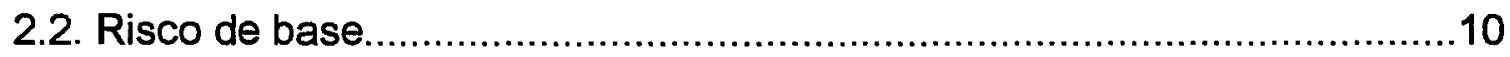

2.3. Liquidação física dos contratos futuros.................................................15

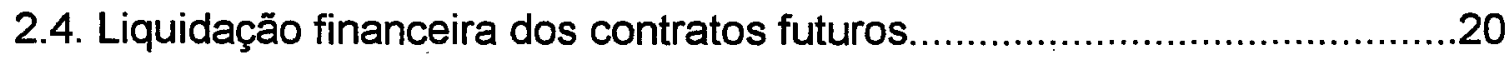

3. O CONTRATO FUTURO DE BOI GORDO DA BM\&F............................28

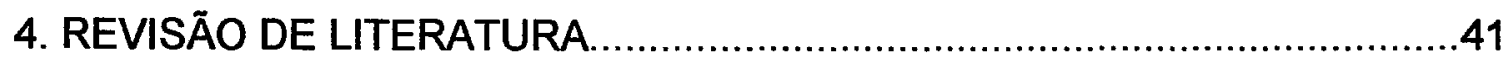

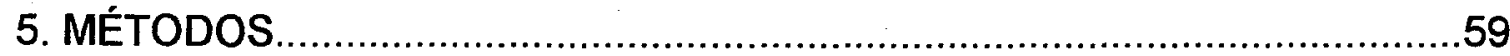

5.1. Método utilizado para analisar o impacto da introdução da liquidação financeira sobre o risco de base na semana que inclui a data de vencimento do contrato.

5.2. Método utilizado para analisar o impacto da introdução da liquidação financeira sobre o risco de base no mês de vencimento do contrato. 
6. RESULTADOS E DISCUSSÃO .83

6.1. Resultados do estudo do impacto da introdução da liquidação financeira sobre o risco de base na semana de vencimento do contrato. .83

6.1.1. Resultados dos testes de igualdade de variâncias da base na semana de vencimento do contrato.

6.1.2. Resultados do modelo de regressão do desvio padrão da base na semana de vencimento do contrato.

6.2. Resultados do estudo do impacto da introdução

da liquidação financeira sobre o risco de base no mês de vencimento do contrato.

6.3. Resultados do estudo do impacto da introdução

da liquidação financeira sobre o nível médio da base

na semana de vencimento do contrato.

7. CONCLUSÕES. 104

REFERÊNCIAS BIBLIOGRÁFICAS 109

Apêndice. 
1. Convergência de preços com entrega física

2. Condições necessárias e suficientes para a introdução da liquidação financeira. .25

3. Evolução do número de contratos futuros de boi gordo negociados mensalmente no período de junho de 1991 a fevereiro de 1997 .86

4. Base para machos na semana de vencimento de cada contrato, para as regiōes que compõem o cálculo do IBG. 99

5. Base para machos na semana de vencimento de cada contrato, para as regiões que não compõem o cálculo do IBG. .99

6. Base para fêmeas na semana de vencimento de cada contrato, para as regiões que compõem 0 cálculo do IBG. 100

7. Base para fêmeas na semana de vencimento de cada contrato, para as regiões que não compõem o cálculo do IBG 


\section{LISTA DE TABELAS}

Tabela $n^{\circ}$

Página

1. Variância da base na semana de vencimento do contrato, para machos e fêmeas, nos períodos anterior e posterior à introdução da liquidação financeira e resultados dos testes de Levene modificado para machos e fêmeas em cada região. .84

2. Resultados da regressão do desvio padrão da base na semana de vencimento do contrato, em função de variáveis binárias para liquidação financeira, sexo e localização.

3. Resultados dos testes " $F$ " sobre a igualdade dos coeficientes das variáveis para localização.

4. Resultados das regressões do desvio padrão da base para machos no mês de vencimento do contrato em função da liquidação financeira e sazonalidade. .93

5. Redução percentual no risco de base para machos durante o mês de vencimento do contrato, para cada região.

6. Resultados das regressões do desvio padrão da base para fêmeas no mês de vencimento do contrato em função da liquidação financeira e sazonalidade. 
7. Redução percentual no risco de base para fêmeas durante o mês de vencimento do contrato, para cada regiāo

8. Base média na semana de vencimento dos contratos, antes e depois da introdução da liquidação financeira $e$ resultados dos testes $t$ 


\title{
O CONTRATO FUTURO DE BOI GORDO: UMA ANÁLISE DO IMPACTO DA INTRODUÇÃO DA LIQUIDAÇÃO FINANCEIRA SOBRE O RISCO DE BASE
}

\author{
Autora: THEREZA CHRISTINA PIPPA ROCHELLE \\ Orientador: Prof. Dr. JOAQUIM BENTO DE SOUZA FERREIRA FILHO
}

RESUMO

A liquidação financeira para o contrato futuro de boi gordo da BM\&F foi introduzida a partir do contrato com vencimento em agosto de 1995. A Bolsa esperava, com isso, torná-lo mais útil como mecanismo de administração de risco e aumentar sua utilização pelos agentes do mercado.

Este estudo foi desenvolvido para verificar o impacto da introdução da liquidação financeira sobre o risco de base do contrato futuro de boi gordo da BM\&F. O risco de base foi representado pela sua variância e a análise foi feita para animais machos e fêmeas, em 9 regiões: Araçatuba, Bauru/Marília, Barretos/São José do Rio Preto, Presidente Prudente, Três Lagoas, Triângulo Mineiro, Campo Grande, Goiânia e Norte do Paraná. As quatro primeiras regiões compõem o cálculo do Indicador de Preço Disponivel do Boi Gordo (IBG), utilizado para liquidar o contrato futuro.

Para verificar se e como a adoção da liquidação financeira afetou o risco de base na semana de vencimento do contrato, foram utilizados testes para igualdade de variâncias nos períodos anterior e posterior a ela. Foi estimado um modelo de regressão do desvio padrão da base contra variáveis binárias, para isolar o impacto da liquidação financeira sobre o risco de base e identificar se este difere entre regiões e entre sexos. 
para isolar o impacto da liquidação financeira sobre o risco de base e identificar se este difere entre regiões e entre sexos.

Analisou-se o risco de base durante o mês de vencimento do contrato para identificar se e como este foi afetado pela introdução da liquidação financeira e se este difere para meses de vencimento no período de safra e entressafra da oferta de gado bovino para abate. Para tanto, foi estimada uma regressão para cada região e para cada sexo, na qual se expressou o desvio padrão mensal da base em função de variáveis binárias para representar esses efeitos.

Adicionalmente, analisou-se o nível médio da base na semana de vencimento do contrato futuro, para verificar se e como a introdução da liquidação financeira afetou a convergência dos preços à vista e futuro.

Os resultados obtidos no presente estudo permitiram as seguintes conclusões:

- após a introdução da liquidação financeira, o risco de base foi reduzido para machos e fêmeas, em todas as regiões consideradas;

- a liquidação financeira foi responsável por uma redução de $76,08 \%$ no risco de base;

- o risco de base apresentou-se menor para machos em relação às fêmeas, uma vez que os primeiros são objetos de negociação do contrato;

- as regiões que compõem o cálculo do IBG apresentaram menor risco de base em relação às demais consideradas no estudo. Contudo, apenas em alguns casos essa diferença foi significativa;

- a análise do risco de base durante o mês de vencimento do contrato indicou que ele também foi reduzido, após a introdução da liquidação financeira;

- o risco de base apresentou-se menor para os contratos com meses de vencimento na safra em relação àqueles que vencem na entressafra da oferta de gado bovino para abate; 
- os níveis médios da base na semana de vencimento do contrato futuro indicaram melhor convergência entre os preços à vista e futuro, implicando numa melhoria da performance do hedging. 


\title{
FED CATTLE FUTURES CONTRACT: AN ANALYSIS OF CASH SETTLEMENT IMPACTS ON BASIS RISK
}

\author{
Author: THEREZA CHRISTINA PIPPA ROCHELLE \\ Adviser: JOAQUIM BENTO DE SOUZA FERREIRA FILHO
}

\section{SUMMARY}

Cash settlement for BM\&F fed cattle futures contract was introduced for the August 1995 contract maturity month. Such institution expected to make it more useful as a risk management tool and increase its utilization by market agents.

This research has been developed to assess the impact of cash settlement on the BM\&F fed cattle futures contract basis risk. The latter was measured by basis variance and the analysis was made of both male and female animals in 9 different regions: Araçatuba, Bauru/Marília, Barretos/São José do Rio Preto, Presidente Prudente, Três Lagoas, Triângulo Mineiro, Campo Grande, Goiânia and Norte do Paraná. The first four regions have been included in the calculation of the Indicador de Preço Disponivel do Boi Gordo (IBG), used for the fed cattle futures contract settlement.

In order to assess if and how the adoption of cash settlement had affected basis risk during the contract maturity week, tests about the equality of variances have been performed for pre and post cash settlement periods thereto. A standard deviation regression model was estimated with dummy 
variables to isolate the impact of cash settlement on basis risk and assess whether the latter differs across regions and between sexes.

Basis risk was analyzed during contract maturity month to identify if and how it was affected by the introduction of cash settlement and to detect seasonal effects on basis risk. For this purpose, a regression was estimated for each region and sex in which basis monthly standard deviation was expressed in function of dummy variables to represent these effects.

Moreover, the mean basis levels on the contract maturity week was analyzed, to assess if and how the introduction of cash settlement had affected cash and futures prices convergence.

The results of this research led to the following conclusions:

- after the introduction of cash settlement basis risk has been reduced for males and females in all concerned regions;

- cash settlement accounted for $76,08 \%$ reduction on basis risk;

- basis risk was lower for males than for females since the contract is designed for oxes;

- the regions comprised by IBG calculation showed lower basis risk in relation to the other researched regions. Only in few cases however such differences were statistically significant;

- the basis risk analysis during the contract maturity month indicated that such risk has also been reduced after cash settlement introduction;

- basis risk showed lower for the contracts with maturity months in the first semester of the year in relation to those in the second semester;

- mean basis levels in the contract maturity weeks indicated that cash and futures prices convergence has been improved, allowing better hedging performance. 


\section{INTRODUÇÃO}

No Brasil, o mercado futuro de commodities agropecuárias é operado na Bolsa de Mercadorias \& Futuros (BM\&F), onde, através de Pregões públicos, são negociados os contratos futuros. A negociação do boi gordo em mercados futuros ocorre desde 1980, época em que os contratos eram operados na Bolsa de Mercadorias de São Paulo, hoje fundida à BM\&F. Operam, no mercado futuro de boi gordo, pecuaristas, frigoríficos, especuladores e agentes financeiros.

Um pecuarista fará um hedge de venda (short hedge) ou tomará a posição vendida em contratos futuros, com o objetivo de assegurar um preço alvo para a venda do boi gordo. Já um frigorífico, tomará a posição comprada em contratos futuros, ou seja, fará um hedge de compra (long hedge), através da aquisição de contratos futuros que garantam a compra do boi gordo por um preço preestabelecido pela empresa. $O$ especulador, que tem por objetivo ganhar com a alta ou queda dos preços do boi gordo, toma para si os riscos da oscilação de preços e garante a liquidez do mercado, isto é, garante que o hedger que queira encerrar sua posição em mercados futuros possa fazê-lo a qualquer momento.

Em 1986, quando entrou em vigência o Plano Cruzado, as operações com contratos futuros de boi gordo foram encerradas por imposição governamental. Nos anos seguintes, tentou-se reativar o mercado, que só voltou a operar em 1991. Essa versão do contrato futuro estabelecia obrigatoriedade da liquidação por entrega física no vencimento. 0 vendedor 
tinha a atribuição de entregar os animais e o comprador habilitado ao recebimento era responsável por sua retirada da fazenda do vendedor. No mercado à vista, tal é o procedimento habitual, todavia, operando em mercados futuros, surgiram dificuldades em padronizar os lotes de animais de acordo com as especificações do contrato.

Apesar de menos de $2 \%$ dos contratos negociados resultarem na entrega física dos animais, ao longo dos últimos anos, foram realizados aperfeiçoamentos no contrato futuro de boi gordo, de forma a superar as dificuldades causadas por essa forma de liquidação. Entre as modificações, talvez a mais importante tenha sido a introdução da liquidação financeira ${ }^{1}$ para esse contrato, em dezembro de 1994, tendo ocorrido a primeira liquidação financeira efetiva para o contrato futuro com vencimento em agosto de 1995.

Alguns dos problemas com a liquidação por entrega física do contrato futuro do boi gordo da BM\&F eram: 1) atritos entre compradores e vendedores, gerados porque o short hedger sempre procurava entregar a mercadoria com padrões mínimos estabelecidos no contrato e o long hedger, sentindo-se prejudicado, solicitava arbitragem à BM\&F. Essa situação gerava constrangimento e custos adicionais para os participantes e era desgastante para a Bolsa; 2) elevados custos envolvidos no procedimento de entrega dos animais; 3) possíveis oscilações de preço em mercados regionais, perto da data de vencimento do contrato, refletindo a oferta e demanda antecipada da mercadoria objeto do contrato, por parte dos agentes que não tinham conseguido sair do mercado até aquela data e teriam de receber ou entregar os animais; 4) a possibilidade de não conseguir sair do mercado até o vencimento, poderia culminar com a entrega ou recebimento da mercadoria, afastando

\footnotetext{
${ }^{1}$ Na liquidação financeira não há negociação física da mercadoria. O contrato futuro é liquidado na data de vencimento, através de um índice que representa os preços no mercado à vista. Este assunto será tratado com mais detalhes na seção 2.4.
} 
especuladores e investidores institucionais e reduzindo a liquidez do mercado; 5) possibilidade de squeezes ${ }^{2}$ no vencimento, devido à falta de liquidez.

A despeito dos problemas apresentados pela entrega física, é a possibilidade de que ela ocorra que garante a convergência dos preços `a vista e futuro. Contudo, no caso de animais, as dificuldades de padronização da commodity e os custos de deslocamento do produto dificultam as operações de arbitragem para forçar os preços a convergirem e acabam elevando o risco de base dos contratos.

\subsection{O problema e sua importância}

Ao assumir posiçōes em mercados futuros, o agente procura minimizar o risco de preço no mercado à vista, sujeito ao retorno esperado. De acordo com Netz (1996), sob esse enfoque, o agente encara o risco de base (da porção dos ativos que está hedgeada) e o risco de preço (da porção não-hedgeada dos ativos). Assim, espera-se que quanto menor for o risco de base, maior será a utilidade dos contratos futuros como mecanismo de transferência de risco e garantia de preço, e maior poderá ser sua utilização pelos agentes do mercado.

Os custos e problemas gerados pelo mecanismo de entrega física dos animais dificultam o arbitramento de preços nos mercados à vista e futuro, prejudicando sua convergência. Essa situação eleva o risco de base e prejudica o desempenho do hedging, o que pode desestimular os agentes a integrarem o mercado. Assim, a BM\&F adotou a liquidação financeira para o contrato futuro de boi gordo, esperando, com essa mudança, promover melhorias na performance do hedging. Contudo, não é adequado assumir,

\footnotetext{
${ }^{2}$ Squeeze é uma situação em que o agente short em mercados futuros não pode inverter sua posição ou encontrar a commodity para entregar, exceto por um preço substancialmente maior do que o valor relativo desse contrato ou dessa commodity no mercado.
} 
preliminarmente, que a liquidação financeira reduz o risco de base pela eliminação dos custos e problemas da entrega física e melhor convergência dos preços à vista e futuro. Isso só ocorrerá se o índice utilizado para liquidar o contrato representar adequadamente os preços no mercado à vista.

Entretanto, espera-se que a introdução da liquidação financeira altere os níveis médios da base na semana que inclui a data de vencimento do contrato, uma vez que o preço para liquidá-lo é representado por um índice, calculado como uma média dos preços à vista de diversas regiões. Todavia, não é possivel afirmar, a priori, se a introdução da liquidação financeira leva a aumento ou redução dos níveis médios da base na semana que inclui a data de vencimento do contrato.

Para identificar se e como a alteração na forma de liquidação propiciou melhoria nas condições para realização do hedging, via redução do risco de base, torna-se importante e necessário analisar o impacto da introdução da liquidação financeira sobre a variabilidade da base do contrato futuro de boi gordo da BM\&F.

Adicionalmente, analisar o nível médio da base é importante para saber se a introdução da liquidação financeira e das demais modificações nas especificações do contrato levaram a uma melhor convergência entre os preços à vista e futuro, na data de vencimento do contrato. Uma base mais próxima de zero no vencimento do contrato implica em melhor convergência entre esses preços e quanto melhor essa convergência, melhor a representatividade do indice de preços à vista e melhor o funcionamento do mercado futuro.

Desta forma, será possível verificar se as medidas implementadas pela BM\&F contribuíram efetivamente para redução do risco de base do contrato futuro de boi gordo e para o aumento da performance do hedging, propiciando condições para que o mercado funcione cada vez melhor e incentive continuamente a entrada de novos participantes. 


\subsection{Objetivos}

O objetivo deste estudo é analisar o impacto da introdução da liquidação financeira sobre o risco de base do contrato futuro cambial de boi gordo da BM\&F. Para isso, nove regiões foram consideradas, a saber: Araçatuba, Bauru/Marília, Barretos/São José do Rio Preto, Presidente Prudente, Três Lagoas, Triângulo Mineiro, Campo Grande, Goiânia e Norte do Paraná. No presente estudo, o risco de base, que caracteriza o risco do hedging, será representado pela variância da base e esses termos serão usados como sinônimos, a partir desta seção. Especificamente, pretende-se:

1) verificar, em cada região e para cada sexo, se a introdução da liquidação financeira afetou a variância da base na semana que inclui a data de vencimento do contrato, através de testes de hipóteses para a igualdade de variâncias dos periodos anterior e posterior a ela;

2) analisar o volume de contratos negociados antes e depois da introdução da liquidação financeira, a fim de verificar o argumento de que se a mudança na forma de liquidação reduz o risco de base, os agentes podem sentir-se estimulados a integrar o mercado futuro de boi gordo, elevando o número de contratos negociados;

3) isolar o impacto da liquidação financeira sobre o risco de base na semana que inclui a data de vencimento do contrato, de outras modificações introduzidas ao mesmo tempo. A inclusão de variáveis binárias para sexo e localização no modelo, permitirá analisar a variância da base para diferentes regiōes e entre sexos;

4) investigar se a introdução da liquidação financeira afetou o risco de base durante o mês de vencimento do contrato, através de um modelo de regressão para cada sexo e para cada região considerada no estudo. Adicionalmente, outra variável binária será incluída no modelo, para verificar se o risco de base 
difere para os contratos com mês de vencimento na safra e na entressafra da oferta de bovinos para abate;

5) verificar, para cada região e para cada sexo, se a introduçã̃o da liquidação financeira melhorou a convergência dos preços à vista e futuro, pela eliminação dos custos e problemas relacionados à entrega física. Para isso, serão testadas hipóteses sobre o valor médio da base para os períodos anterior e posterior à introdução da liquidação financeira na semana que inclui a data de vencimento do contrato. 


\section{FUNDAMENTAÇÃO TEÓRICA}

\subsection{A Base}

Leuthold, Junkus \& Cordier (1989) definem base como a diferença entre o preço à vista em um local específico e o preço de um contrato futuro em particular. É chamado de hedging perfeito aquele em que a base é zero no vencimento do contrato; na prática, porém, esse dificilmente ocorre. A base pode ser positiva, quando o preço à vista estiver acima da cotação no mercado futuro ou pode ser negativa, quando ocorrer o oposto. Quando o preço à vista cresce mais do que o preço futuro, a base aumenta e diz-se que houve um fortalecimento da base. Quando o preço futuro cresce mais do que o preço à vista, a base diminui e diz-se que houve um enfraquecimento da base (Hull, 1996).

A base para commodities estocáveis comporta-se diferentemente da base para commodities não-estocáveis. Para explicar a diferença de comportamento nos dois casos, os parágrafos seguintes baseiam-se em Rich (1990).

Para commodities estocáveis, a diferença entre os preços à vista e futuro depende do custo de carregamento ${ }^{3}$, que por sua vez depende das taxas de juros e dos custos de armazenagem e transporte, que variam em função das

${ }^{3} 0$ custo de carregamento mede o custo de armazenagem mais o juro pago para financiar 0 ativo, menos o rendimento obtido com o mesmo (Hull, 1996). 
condições de oferta e demanda. Contudo, o preço futuro não excederá o preço à vista de uma quantia maior do que o custo de carregamento, pois, caso isso ocorra, haverá possibilidade de arbitragem entre os mercados à vista e futuro, forçando os preços no sentido de igualar a diferença entre eles ao custo de carregamento. Considerando que os fatores que compõem esse custo são relativamente estáveis, a base para commodities estocáveis também o é. Nesse caso, o mercado futuro tem provado ser um mecanismo efetivo de transferência de risco para tais commodities.

No caso de commodities não-estocáveis, a teoria sobre a base não está tão bem desenvolvida. Para animais vivos, a relação entre os preços à vista e futuro não é tão estável como para commodities estocáveis, porque aqueles são continuamente produzidos e distribuídos, sem uma oferta fixa ou formação de estoques. Uma vez que a oferta não é fixa, os preços futuros de commodities não-estocáveis devem representar uma antecipação do preço à vista para uma data no futuro. Como essa antecipação do preço da commodity para uma data no futuro é feita com base nas informações disponiveis no mercado à vista, a chegada de novas informações faz com que a base torne-se mais instável para commodities não-estocáveis do que para as estocáveis.

Além disso, as operações de arbitragem tornam-se mais difíceis para contratos de animais vivos, devido à dificuldade de padronizar os lotes e aos demais custos relacionados ao deslocamento dos mesmos. É necessário que a diferença entre os preços à vista e futuro seja suficientemente grande para compensar as despesas com a entrega da mercadoria e ainda incentivar as operações de arbitragem. Assim, a convergência entre os preços à vista e futuro esperada durante o mês de vencimento do contrato pode não ocorrer.

Garcia et al. (1984) afirmam que os movimentos imprevisiveis da base reduzem a capacidade dos mercados futuros de transferir risco dos hedgers para os especuladores e podem resultar em menor receita para esses agentes. Neste contexto, pode-se afirmar que quanto menos a base flutuar 
aleatoriamente, maior será a utilidade desses mercados como instrumento de administração de risco. Explica-se, a seguir, a fundamentação desta relação.

De acordo com a teoria do portfólio, o hedger tenta minimizar o risco de suas posições à vista e futura, sujeito ao retorno esperado (Castelino, 1989). A referida teoria aborda a seleção e combinação de investimentos individuais, de tal forma que, quando tomados em conjunto, eles maximizam o retorno, sujeito ao nivel de risco total estabelecido. Analogamente, o mesmo conjunto de investimentos também minimiza o risco total, sujeito ao retorno esperado (Leuthold, Junkus \& Cordier, 1989). Surge, então, o conceito de razão de hedge de variância mínima, que è aquela que minimiza o risco total das posições à vista e futura, sujeito ao retorno esperado.

Segundo Geppert (1995), objetivando minimizar a variância da mudança no valor do portfólio, a equação (1), formalmente, apresenta a situação enfrentada pelo hedger.

$$
\begin{aligned}
& \operatorname{Min} \operatorname{Var}\left(\Delta H P_{t}\right)=\operatorname{Var}\left(\Delta S_{t}+N \Delta F_{t}\right) \\
& \operatorname{Min} \operatorname{Var}\left(\Delta H P_{t}\right)=\operatorname{Var}\left(\Delta S_{t}\right)+N^{2} \operatorname{Var}\left(\Delta F_{t}\right)+2 N \operatorname{Cov}\left(\Delta S_{t}, \Delta F_{t}\right)
\end{aligned}
$$

onde $\Delta H P_{t}$ é a mudança no valor do portfólio do hedger durante o período $t$; $\Delta S_{t}$ e $\Delta F_{t}$ são mudanças nos preços à vista e futuro, respectivamente, no período $t$ e $N$ é a razão de hedge. Resolvendo a equação (1) para a razão de hedge que minimiża a variância no valor do portfólio, obtém-se a equação (2):

$$
\begin{aligned}
& \frac{\delta \operatorname{Var}\left(\Delta H P_{t}\right)}{\delta N}=2 N \operatorname{Var}\left(\Delta F_{t}\right)+2 \operatorname{Cov}\left(\Delta S_{t}, \Delta F_{t}\right)=0 \\
& N^{*}=-\frac{\operatorname{Cov}\left(\Delta S_{t}, \Delta F_{t}\right)}{\operatorname{Var}\left(\Delta F_{t}\right)}
\end{aligned}
$$


onde $N^{*}$ é a razão de hedge de variância mínima ou razão ótima de hedge, que é igual ao coeficiente de inclinação de uma regressão de mínimos quadrados ordinários das variações do preço à vista contra as variações do preço futuro no tempo 4 .

Pode-se concluir, desta forma, que fazendo-se a regressão de $\Delta S_{t}$ contra $\Delta F_{t}$, a soma de quadrados de resíduos da estimação, ou seja, a porção da variação das diferenças dos preços à vista e futuro que não é explicada pelo modelo, constitui a parte do risco que não é eliminada pelo hedging de variância mínima. Assim, deduz-se que quanto menor for a variância do erro de estimação da regressão, tanto menor será o risco para o agente que assume posições em mercados futuros. Em outras palavras, quanto menor a variância da porção aleatória da base, menor será o risco do hedging e maior a utilidade dos contratos futuros como instrumento para administrá-lo.

\subsection{Risco de Base}

O risco de base surge dos movimentos inesperados da diferença entre os preços à vista e futuro, ou seja, quanto mais a base oscilar aleatoriamente, maior será seu risco. Sendo o risco do hedging caracterizado pelo risco de base, quanto mais a base variar, menor será a utilidade dos mercados futuros como veículo de transferência de risco.

Hull (1996) parte da definição de base, para definir seu risco. Considerando-se que o hedging é iniciado no instante $t_{1}$ e encerrado no instante $t_{2}$, define-se $S_{1}$ e $S_{2}$ como preços à vista do ativo a ser hedgeado, nos

\footnotetext{
${ }^{4}$ Geppert (1995) observa que a especificação e a técnica de estimação da regressão de mínimos quadrados ordinários para obtenção deste valor difere de estudo para estudo. 0 procedimento mais comum é fazer a regressão das variações dos preços à vista contra as variações dos preços futuros, com correções para autocorrelação.
} 
instantes $t_{1}$ e $t_{2}$, respectivamente, $F_{1}$ e $F_{2}$ como preços futuros do contrato utilizado, nos instantes $t_{1}$ e $t_{2}$, respectivamente e $b_{1}$ e $b_{2}$, como bases nos instantes $t_{1}$ e $t_{2}$, respectivamente. Assim, pela definição de base, tem-se:

$$
\begin{aligned}
& b_{1}=S_{1}-F_{1} \\
& b_{2}=S_{2}-F_{2}
\end{aligned}
$$

O preço a ser pago ou recebido pelo ativo em $t_{2}$ será $S_{2}$ e o prejuízo ou lucro da posição futura será $F_{1}-F_{2}$. Portanto, $\circ$ preço efetivo que $\circ$ agente pagará ou receberá pelo ativo com a realização do hedging está indicado pela equação (5) e será o preço do ativo no mercado à vista em $t_{2}$ mais a diferença entre os preços futuros nos instantes $t_{1}$ e $t_{2}$, respectivamente.

$$
S_{2}+F_{1}-F_{2}
$$

Substituindo a equação (4) em (5), obtém-se:

$$
F_{1}+b_{2}
$$

$F_{1}$ é conhecido no instante em que se inicia o hedging, mas nesse momento não se sabe valor de $b_{2}$. Caso fosse possível conhecer o valor de $b_{2}$ no momento em que se inicia a operação, ter-se-ia um hedging perfeito. O risco do hedging é a incerteza associada a $b_{2}$, que é denominada risco de base.

Se a mercadoria a ser hedgeada possui características diferentes daquela especificada no contrato futuro, a operação é chamada de cross hedge. Neste caso, o risco de base inclui o risco adicional da diferença de 
preço entre esses ativos e caracteriza o risco do cross hedging. Ainda de acordo com Hull (1996), considerando $S_{2}^{*}$ o preço do ativo referenciado no contrato futuro no instante $t_{2}$ e $S_{2}$ o preço do ativo hedgeado no instante $t_{2}, 0$ preço que o hedger pagará ou receberá pelo ativo, através da operação de cross hedge, está indicado na equação (6). Contudo, como o ativo hedgeado e aquele definido no contrato são diferentes, a base pode ser decomposta em dois elementos, de acordo com a equação (7):

$$
b_{2}=\left(S_{2}^{*}-F_{2}\right)+\left(S_{2}-S_{2}^{*}\right)
$$

onde:

$\left(S_{2}^{*}-F_{2}\right)=$ base que existiria se o ativo hedgeado fosse o mesmo estabelecido no contrato;

$\left(S_{2}-S_{2}^{*}\right)=$ base que surge da diferença de preço entre o ativo hedgeado e aquele estabelecido no contrato.

Substituindo a equação (7) em (6), obtém-se o preço que o hedger pagará ou receberá pelo ativo, através da operação de cross hedge:

$$
F_{1}+\left(S_{2}^{*}-F_{2}\right)+\left(S_{2}-S_{2}^{*}\right)
$$

Conforme descrito na equação (8), o risco do cross hedging é caracterizado pelos movimentos imprevisiveis dos dois componentes da base, um que surge da diferença entre os preços à vista e futuro do ativo referenciado no contrato, e outro devido à diferença entre o preço à vista do ativo hedgeado e o preço futuro do ativo especificado no contrato.

Williams (1986) adverte que a análise do risco de base deve ser feita com cuidado. Uma vez que a base é a diferença entre o preço à vista e o preço futuro, alguns de seus movimentos são, de fato, apenas a convergência entre 
eles, conforme se aproxima a data de vencimento do contrato. Sendo previsível, essa parcela dos movimentos da base não deve ser considerada risco de hedging. O verdadeiro risco de base não é atribuído aos movimentos de convergência dos preços à vista e futuro, mas às flutuações imprevisíveis da base.

De acordo com Paroush \& Wolf (1989), existem três fontes para o risco de base: qualidade, localização e tempo. A qualidade refere-se aos atributos do ativo a ser hedgeado, ou seja, quanto mais estas se distanciam daquelas especificadas no contrato, maior é o risco de base. Conforme já comentado, no caso de mercadorias com características diferentes daquelas especificadas no contrato, o risco de base caracteriza o risco do cross hedging.

No que se refere à localização, o risco surge porque o preço da Bolsa pode não refletir o preço do ativo em determinada região, em função das condições de oferta e demanda locais. Se a diferença entre o preço em determinado mercado regional e o preço futuro for estável, pode-se ter uma previsão sobre qual será a base no vencimento do contrato. Entretanto, uma alta variabilidade entre esses preços torna a base menos previsivel e eleva o risco para o hedger.

Finalmente, o risco de base devido ao tempo ocorre porque a variação da base pode ocorrer em função de novas informações sobre as condições de oferta e demanda que se tornam disponiveis no mercado, durante o período em que o hedging está sendo carregado. A freqüência e impacto dessas informações são imprevisíveis e podem afetar o comportamento da base diferentemente em cada ponto da vida do contrato, resultando em niveis de risco diferentes. No período inicial da vigência do contrato, novas informações sobre oferta e demanda tendem a influenciar mais os preços futuros do que os preços à vista. Tais previsões estão sujeitas a erros, porque antecipam os movimentos de oferta e demanda para períodos longínquos. Assim, esses erros podem levar os preços futuros a oscilações indesejadas, elevando o risco de 
base. Conforme a maturidade se aproxima, os preços à vista e futuro estão mais próximos e as informações podem afetar os dois de maneira similar. Neste periodo, os participantes do mercado estão aptos a prever com mais precisão as condições de oferta e demanda, o que, para um dado nivel de informações, pode resultar em previsões mais precisas do preço à vista esperado e reduzir o risco de base (Garcia et al., 1984). Castelino (1989) examinou a relação entre o risco de base e o tempo de duração do hedging. As estimações empíricas foram feitas para mercados futuros de Treasure bill $^{5} \mathrm{e}$ os resultados indicaram que quanto maior a duração do hedging, maior é a volatilidade da base.

De acordo com Netz (1996), o risco de base pode originar-se através do tempo e localização simultaneamente, porque a chegada de informações a cada momento pode afetar os mercados locais e o mercado nacional diferentemente. Informaçōes que afetam os mercados locais exercem impacto sobre os preços à vista regionais, enquanto informações que afetam o mercado nacional exercem impacto sobre os preços futuros, pois eles representam uma média nacional dos preços da commodity.

No caso de commodities de consumo ${ }^{6}$, os detentores do produto podem obter certas vantagens não pertinentes aos detentores de contratos futuros. Essas vantagens são denominadas convenience yield e entre elas pode-se incluir a capacidade de obtenção de lucro na escassez temporária do produto e a manutenção de um processo produtivo em andamento. Assim, desequilíbrios entre oferta e demanda e dificuldades associadas ao armazenamento do produto podem levar a grandes variações no convenience yield, que é outra causa natural do risco de base (Hull, 1996).

A liquidez do mercado à vista é outro fator que afeta o risco de base. Num mercado com alta liquidez, o número de transações é grande e, mesmo

\footnotetext{
${ }^{5}$ Letras do Tesouro dos Estados Unidos.

${ }^{6}$ Hull (1996) diferencia as commodities em duas categorias: de investimento, que são mantidas para investimento, por um número significativo de investidores (por exemplo ouro e prata) e de consumo, possuídas basicamente para esse fim (por exemplo milho e soja).
} 
havendo negociações envolvendo vultosas quantidades de produto, o impacto sobre os preços será limitado. Já em mercados com pouca liquidez, o número de transações é reduzido e negociaçōes com pequenas quantidades de produto são capazes de afetar significativamente os preços. Então, quanto menor a liquidez do mercado, mais voláteis serão os preços à vista em função das condições de oferta e demanda, e maior será o risco de base (Pirrong et al., 1991). Analogamente, espera-se que quanto menor a liquidez do mercado futuro, maior a volatilidade dos preços neste mercado e, conseqüentemente, maior o risco de base.

\subsection{Liquidação Física dos Contratos Futuros}

Na verdade, é a possibilidade de entrega e recebimento da mercadoria que garante a convergência dos preços à vista e futuro. Esta ocorre durante o mês de vencimento, à medida em que se aproxima a maturidade do contrato. Caso existam fatores impedindo a aproximação dos preços, a base varia de forma imprevisível, aumentando o risco do hedging.

Para commodities estocáveis, quando a diferença entre os preços à vista e futuro, no período que precede o vencimento do contrato, é maiór do que o custo de carregamento, existem oportunidades para obtenção de lucro no mercado, através das operações de arbitragem. Se o preço à vista da mercadoria estiver menor do que seu preço futuro, um arbitrador compra o produto no mercado físico, toma posição vendida em futuros e liquida seu contrato pela entrega. Essas transações elevam o preço à vista e reduzem os preços futuros, promovendo a convergência entre eles. $O$ oposto ocorre se 0 preço à vista estiver maior do que o preço futuro.

De acordo com Hull (1996), tais situações são válidas apenas para commodities estocáveis mantidas para fins de investimento. No caso das 
commodities estocáveis de consumo, os indivíduos ou empresas que mantém um estoque, o fazem por seu valor de consumo. Portanto, não estão dispostos a vendê-las nem comprar contratos futuros, já que estes não podem ser consumidos. Assim, a arbitragem dos mercados à vista e futuro para commodities estocáveis de consumo ocorre apenas quando o preço futuro excede o preço à vista de um montante maior do que o custo de carregamento. Desta forma, os arbitradores compram a mercadoria, pagam os custos de armazenagem, tomam posição vendida em futuros e lucram a diferença. Com essas transações o preço à vista tenderá a se elevar e o preço futuro a diminuir.

No caso das commodities não-estocáveis, o arbitramento dos mercados não é tão simples. Considerando-se animais vivos, surgem dificuldades adicionais para padronizair os lotes no mercado físico, uma vez que eles não são perfeitamente homogêneos. É necessário, ainda, considerar os custos associados à transmissão de doenças, mortalidade, diferenças de qualidade, peso, sexo, raça, transporte e manuseio (devido ao volume do produto envolvido) e mudanças fisiológicas que ocorrem com a maturidade do animal. Por tais razões, não é possivel supor que as operações de arbitragem sempre irão corrigir os spreads de preços desalinhados para futuros de animais vivos, especialmente pequenas imperfeições de curto prazo (Rich, 1990).

A liquidação dos contratos futuros por entrega soma aos custos e problemas relacionados ao mercado físico, custos adicionais relativos ao mercado futuro, que incluem a emissão de aviso de entrega, inspeção e certificação da commodity e registro de transferência. Assim, os custos relacionados à entrega da mercadoria para liquidar o contrato prejudicam a convergência dos preços, ampliando o risco de base.

Outro problema que surge com a liquidação física é que esta ocorre sempre através da entrega da mercadoria com padröes mínimos estabelecidos no contrato, ou seja, o hedger com posição vendida (short hedger) procurará 
entregar a mercadoria com os mínimos padrões de qualidade determinados no contrato. Por sua vez, o hedger com posição comprada (long hedger) poderá recusar tal mercadoria se considerá-la inferior às especificações ou exigir um deságio no preço para recebê-la. Esses atritos levam as Bolsas a designar um árbitro para verificar a qualidade da mercadoria e resolver o impasse. Porém, todo esse procedimento gera incertezas e custos adicionais aos participantes, elevando o risco de base.

A este respeito, Frick (1995) observa que "custos operacionais (taxas de corretagem) diferenciados entre mercados, bem como procedimentos de comercialização não coincidentes (exigência de deslocamento do produto, etc.) levam a dificuldades nas possibilidades de arbitrar os mercados, para forçar a convergência de preços e isso acaba por ampliar o risco de base".

Adicionalmente, a liquidação física pode levar os preços à vista e futuro a não convergir, porque os agentes, esperando receber ou entregar a mercadoria, afetam as condições de oferta e demanda da commodity objeto de entrega em mercados locais, gerando imperfeições no preço à vista e elevando o risco de base.

Quando a data de vencimento do contrato se aproxima e a liquidação se der por entrega física, a demanda pela commodity objeto de entrega por parte dos especuladores com posição vendida em contratos futuros poderá levar a um aumento no preço da mercadoria padronizada no contrato, no mercado à vista (local de entrega) onde a compra é realizada. Por outro lado, se especuladores com posição comprada esperam receber grande quantidade do produto em determinado ponto de entrega, o aumento da oferta nesse mercado à vista pode causar uma queda nos preços locais. Assim, essas distorções fazem com que a convergência entre os preços à vista e futuro não ocorra, elevando o risco de base.

De acordo com Garbade \& Silber (1983), us dois principais problemas relacionados com a liquidação física são os elevados custos de entrega e os 
movimentos antecipados de oferta e demanda em mercados locais, causados pelos especuladores que não conseguiram sair do mercado até a data de vencimento do contrato. Os autores explicam, através da figura 1, como esses problemas prejudicam a convergência dos preços à vista e futuro, quando a liquidação ocorre por entrega física.

Figura 1. Convergência de preços com entrega física.

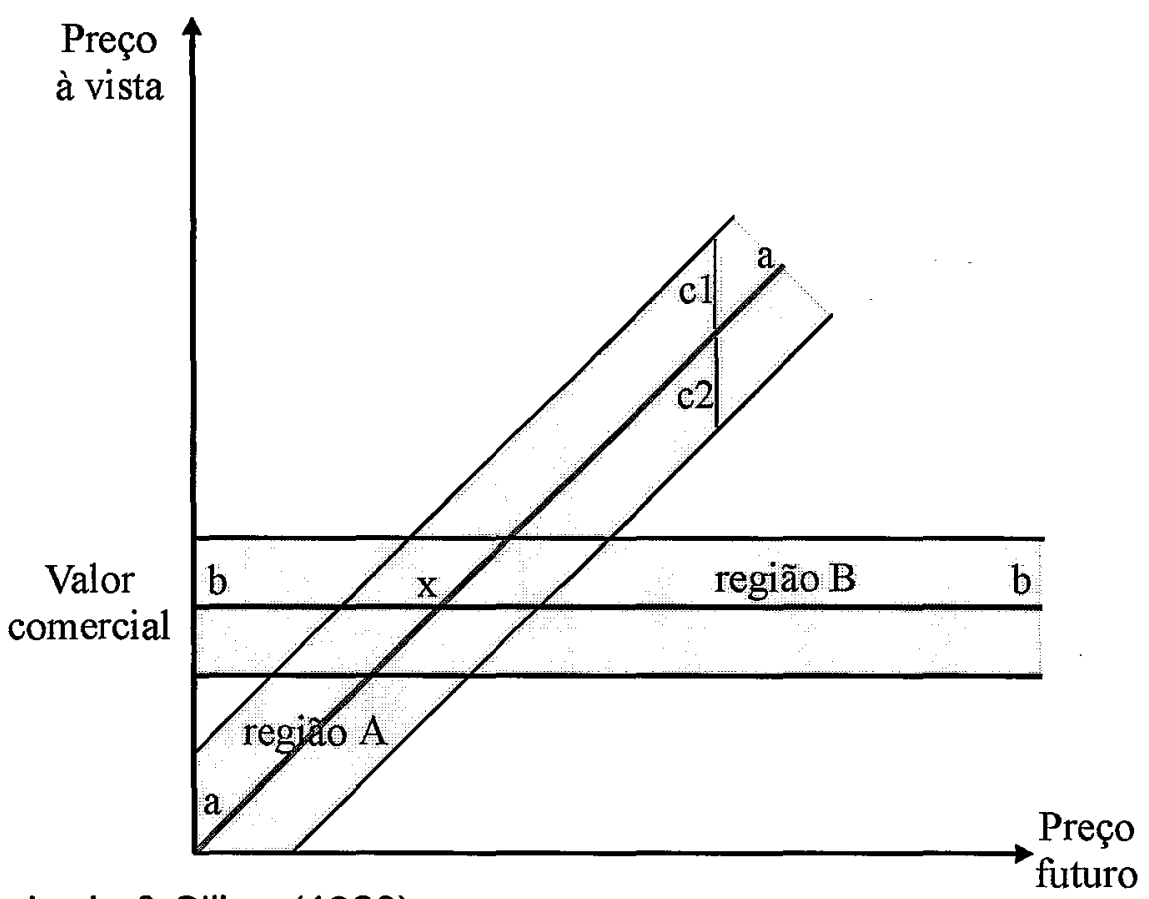

Fonte: Garbade \& Silber (1983)

Numa situação ideal, o preço à vista deveria igualar-se exatamente ao valor comercial da commodity ${ }^{7}$ neste mercado (ponto de interseção da linha bb com o eixo vertical), enquanto o preço futuro deveria igualar-se ao preço à vista, conforme se aproxima a data da liquidação do contrato (qualquer ponto da linha aa, com inclinação de $45^{\circ}$ ). Desta forma, os preços à vista e futuro

\footnotetext{
${ }^{7}$ O termo valor comercial da commodity refere-se ao preço à vista da mercadoria, isento de distorções, como a ocorrência de squeezes e corners, que são tentativas de manipulação de preço nos mercados à vista e futuro.
} 
convergiriam para o ponto $\mathbf{X}$ (ponto de interseção das linhas aa e $\mathbf{b b}$ ) na figura 1 e ambos se igualariam ao valor comercial da commodity. Entretanto, os custos e problemas relacionados à entrega prejudicam as operações de arbitragem. Devido a eles, o preço à vista pode ficar acima (abaixo) do preço futuro, de um montante igual ao custo c1 (c2) na figura 1. Então, a combinação dos preços à vista e futuro ficará num ponto na região A (área sombreada). Por outro lado, a demanda pela commodity, por parte dos especuladores com posição vendida em futuros, para entrega da mercadoria especificada no contrato, pode levar a um aumento de preço no mercado à vista onde a compra é realizada. Analogamente, se os especuladores com posição comprada em futuros esperam a entrega de uma grande quantidade de mercadoria, suas vendas antecipadas no mercado à vista podem levar a uma redução dos preços neste mercado, fazendo com que o preço à vista fique abaixo do valor comercial neste mercado. Devido a essas situações, o preço à vista está sujeito a imperfeições e poderá ser qualquer ponto dentro da região $\mathbf{B}$ (área sombreada). Assim, a convergência dos preços à vista e futuro não será em direção ao ponto $\mathbf{X}$ da figura 1 , que representa o valor comercial da commodity no mercado à vista, mas poderá ocorrer em direção a qualquer ponto dentro da área de interseção das regiões $\mathbf{A}$ e $\mathbf{B}$.

Working (1953) afirma que um contrato futuro só terá sucesso se os preços à vista e futuro convergirem para o valor comercial da commodity, na data do vencimento do contrato. Adicionalmente, Garcia \& Sanders (1996) afirmam que quando o risco de base aumenta: a) a capacidade dos contratos futuros de transferir risco é reduzida; b) torna-se mais difícil avaliar o mercado num futuro próximo e identificar oportunidades de preços e c) a utilização dos contratos futuros pode diminuir. Portanto, pode-se concluir que é recomendável eliminar os custos e problemas relacionados à entrega física, que prejudicam a convergência dos preços e aumentam o risco de base, para que os contratos 
futuros sejam mais úteis como instrumento de transferência de risco e amplamente utilizados pelos participantes do mercado.

\subsection{Liquidação Financeira dos Contratos Futuros}

A liquidação financeira apresenta-se como uma alternativa à liquidação física, que elimina os fatores que prejudicam a convergência dos preços à vista e futuro. Os custos e problemas relacionados à entrega da mercadoria, os atritos causados pela entrega e recebimento do produto, os movimentos antecipados de oferta e demanda pela commodity objeto do contrato, próximo à data de vencimento, são eliminados. Na liquidação financeira o contrato é ajustado por ùm índice que representa o preço da commodity no mercado à vista no último dia de negociações e as posições são declaradas encerradas.

$\mathrm{Na}$ liquidação financeira, os custos relacionados à entrega e os problemas no mercado à vista, devido aos movimentos antecipados de oferta e demanda pela commodity objeto do contrato, são eliminados. Assim, considerando-se novamente a figura 1 , o preço à vista não diverge do valor comercial da commodity (linha bb). Por outro lado, as transações no mercado futuro forçam esses preços a igualar-se ao índice utilizado para liquidação do contrato na data de vencimento. Então, se esse índice reflete os preços no mercado à vista, o preço futuro convergirá para o valor comercial da commodity e os preços à vista e futuro convergirão para o ponto $\mathbf{X}$ na figura 1 .

Assim, espera-se que a adoção da liquidação financeira proporcione redução no risco de base, via eliminação dos fatores que prejudicam a convergência de preços e aumentam os movimentos imprevisiveis da base, melhorando a performance do hedging e aumentando a utilização dos contratos pelos agentes do mercado.

Adicionalmente, a eliminação dos custos e problemas relacionados à entrega física, pela introdução da liquidação financeira, pode diminuir o risco 
de base, através da redução na flutuação dos preços futuros, durante o período de entrega. Na verdade, o preço futuro pode flutuar dentro de uma faixa ${ }^{8}$, independentemente do preço à vista nos pontos de entrega, durante o período de entrega. Isto ocorre porque agentes nas posições comprada ou vendida em futuros podem querer sair do mercado para não terem que incorrer nos custos, responsabilidades e incertezas decorrentes da liquidação por entrega física. Para isso, estão dispostos a pagar um preço no mercado futuro, acima ou abaixo do preço à vista nos pontos de entrega. Paul ${ }^{9}$, citado por Rich (1990), caracteriza essas situações que geram imperfeições nos preços, como squeezes.

Uma vez que na liquidação financeira os agentes em questão não estão sujeitos a entregar ou receber a mercadoria no vencimento do contrato, as oscilações no preço futuro, durante o período de entrega, deixam de existir, reduzindo o risco de base.

Paul ${ }^{10}$, citado novamente por Rich (1990), afirma que a liquidação financeira pode ser utilizada de quatro formas diferentes: a) obrigatória; b) opcional aos compradores; c) opcional aos vendedores; d) opcional a ambas as partes. Paul, citado por Leuthold (1992), sugere que a liquidação financeira ou a entrega física opcional deve ser utilizada em vez da liquidação financeira obrigatória.

De acordo com Jones (1982), existem três diferenças conceituais básicas entre liquidação financeira e física. A primeira refere-se ao preço de liquidação do contrato. $\mathrm{Na}$ entrega física, o preço para ajustar o contrato na data de vencimento é determinado pelas transações futuras, como o é nos demais dias de negociação. Deve-se acrescentar à colocação do autor que a

\footnotetext{
${ }^{8}$ A zona de flutuação dos preços futuros, independentemente do preço à vista, deve aproximarse dos custos para entregar o produto. Assim, quanto maiores forem estes custos, mais ampla será a faixa dentro da qual os preços futuros irão oscilar.

${ }^{9}$ PAUL, A.B. Pricing implications of alternative delivery mechanisms for futures contracts. Key issues in livestock pricing. Blacksburg: Research Institute of Livestock Pricing, 1987.

${ }^{10}$ Paul, op. cit., p.21.
} 
liquidação física ocorre pelo preço da mercadoria com padrões mínimos para entrega. $\mathrm{Na}$ liquidação financeira, o preço futuro para liquidar o contrato na data de vencimento é igual a um índice, que pode representar uma média de preços em diversos locais e para diferentes especificações de commodities e que é determinado externamente ao mercado futuro. Em segundo lugar, na liquidação financeira não há entregas. A proposta da liquidação física é assegurar a convergência de preços pela possibilidade de entrega da mercadoria. Sob liquidação financeira, a arbitragem entre os mercados à vista e futuro não é necessária à convergência. Esta é imposta pela determinação de que o preço futuro para liquidar o contrato na data de vencimento é igual ao índice de preços à vista. Finalmente, a liquidação financeira difere da entrega física, porque pode ser opcional aos agentes com posições futuras short e long entrar no mercado físico, enquanto na entrega física, a troca de produto é obrigatória, para quem se mantém no mercado até a data de vencimento do contrato.

Apesar de a liquidação financeira eliminar os problemas relacionados com a entrega física, a principal dificuldade para adotá-la é a determinação de um índice que represente adequadamente os preços no mercado à vista. Para que o índice para liquidação financeira possa representar esses preços, é necessário que o conjunto dos valores à vista, a partir do qual será calculado o indice, represente apropriadamente os preços. De acordo com Jones (1982), para que isso ocorra, os preços no mercado à vista devem ser:

1) uniformes e representar um padrão para a atividade;

2) conhecidos e amplamente disponíveis;

3) um indicador do valor da commodity,

4) não susceptiveis de manipulação. 
Jones (1982), Garbade \& Silber (1983) e Paul ${ }^{11}$, citado por Hsiang \& Lien (1996), afirmam que, quando o contrato futuro é liquidado por um índice que representa uma média de preços (liquidação financeira), a base torna-se mais previsivel do que quando é utilizado o preço do produto em determinado local (liquidação física) e que isso pode reduzir o risco de base e melhorar a performance do hedging.

$\mathrm{Na}$ verdade, qualquer oscilação brusca nos preços de um mercado individual é "diluída" ao proceder-se o cálculo do índice. Assim, espera-se que a média varie menos do que o preço da mercadoria com os padrões mínimos para entrega, utilizado para liquidação física. Desta forma, a liquidação financeira pode tornar a previsão da base mais fácil, reduzindo o risco e melhorando a performance do hedging.

Apesar da possibilidade do risco de base ser reduzido pela introdução da liquidação financeira, Cohen \& Gorham ${ }^{12}$, citados por Kenyon et al. (1991), afirmaram que o risco de base na maturidade do contrato nunca será zero. Isso porque o preço para liquidação financeira pode ser uma média de preços, ao longo do tempo, de diversos locais e especificações de commodities, enquanto - hedger sempre terá o preço do seu produto em determinado local, representando apenas um dos componentes desta média.

Cohen \& Gorham ${ }^{13}$, citados desta vez por Schroeder \& Mintert (1988) e por Rich \& Leuthold (1993), argumentaram que, devido à eliminação da volatilidade dos custos adicionais de se receber ou proceder à entrega física, os niveis da base seriam alterados. Porém, não estava claro se a mudança para liquidação financeira aumentava ou diminuía o nivel médio da base. Eles

\footnotetext{
${ }^{11}$ PAUL, A.B. The role of cash settlement in futures contracts specification. Futures markets: regulatory issues. Washington: American Enterprise Institute for Public Policy Research, 1985. pp. 271-325.

${ }^{12}$ COHEN, L.; GORHAM, M. The projected impact of cash settled commodity contracts on cash/futures price relationships. Proceeding of Applied Commodity Price Analysis, Forecasting and Market Risk Management. Chicago, 1985.

${ }^{13}$ Cohen \& Gorham, op. cit., p.23.
} 
afirmaram, em seu estudo sobre a liquidação financeira do contrato futuro de boi magro da Chicago Mercantile Exchange (CME), que os preços futuros médios poderiam aumentar relativamente aos preços à vista (isto é, reduzir o nível médio da base), porque os preços dos vários mercados seriam uma média, em vez de representar a mercadoria com padrões mínimos para entrega como na liquidação física. Por outro lado, especificações de qualidade, incluindo mercadorias com padrões de qualidade inferior (na liquidação financeira) e a inclusão de áreas de comércio, cujo preço do gado é mais baixo relativamente a outras regiões, poderiam reduzir os preços futuros médios e aumentar o nível médio da base.

Jones (1982) aponta como condições necessárias para a introdução da liquidação financeira a insuficiência de oferta do produto especificado no contrato e elevados custos de entrega. Quanto maiores os custos relacionados à entrega, maior a vantagem de adotar-se a liquidação financeira. A condição suficiente para adotar tal procedimento é a existência de um indice para liquidar os contratos que represente os preços praticados no mercado à vista.

A baixa disponibilidade do produto especificado no contrato nos locais de entrega pode gerar distorções de preço no mercado à vista, uma vez que a oferta insuficiente do produto possibilita a manipulação dos preços. Desta forma, a liquidação financeira surge como alternativa para eliminar esses problemas. De fato, Garbade \& Silber (1983) também afirmam que a introdução da liquidação financeira permite flexibilidade no desenho do contrato.

Como na liquidação financeira o índice pode representar uma média dos preços de diversas especificações da mercadoria e locais de entrega, ampliar os tipos de produtos especificados nos contratos futuros só afetaria a média do indice de preços, sendo possivel, desse modo, aumentar a oferta passível de entrega sem elevar o risco de base. Já para a entrega física, tal procedimento não teria o mesmo efeito. Nesse caso, ampliando-se os tipos de produto passiveis de entrega, conforme variam os preços à vista, ora uma, ora outra 
torna-se a mercadoria com padrões mínimos passivel de entrega. Portanto, não haveria uma relação estável entre o preço futuro e o preço à vista de uma mercadoria em particular. Conseqüentemente, quanto mais categorias passiveis de entrega e quanto mais heterogêneo o comportamento dos preços entre elas, menos estável será a relação entre os preços à vista e futuro para qualquer mercadoria e maior será o risco de base (Jones, 1982).

Jones (1982) resume as condições necessárias e suficiente para a introdução da liquidação financeira na figura 2.

Figura 2. Condições necessárias e suficiente para a introdução da liquidação financeira.

\begin{tabular}{|c|c|c|c|}
\hline \multirow{3}{*}{$\begin{array}{l}\text { Qualidade dos preços à } \\
\text { vista para o cálculo do } \\
\text { índice }\end{array}$} & \multicolumn{3}{|c|}{ Disponibilidade de oferta } \\
\hline & \multicolumn{2}{|c|}{ Adequada } & \multirow[t]{2}{*}{ Inadequada } \\
\hline & $\begin{array}{l}\text { Custos de entrega } \\
\text { elevados }\end{array}$ & Custos de entrega baixos & \\
\hline Boa & $\begin{array}{l}\text { Liquidação financeira } \\
\text { (Eurodollars TDs) }\end{array}$ & $\begin{array}{lr}\text { Entrega } & \text { física } \\
\text { liquidação } & \text { financeira } \\
\text { (moedas) } & \\
\end{array}$ & $\begin{array}{l}\text { Liquidação financeira } \\
\text { (Eurodollars } C D s \text { ) }\end{array}$ \\
\hline Ruim & Entrega física (gado) & $\begin{array}{l}\text { Entrega física (ouro e } \\
\text { barrigada de porco) }\end{array}$ & Nenhum contrato futuro \\
\hline
\end{tabular}

Fonte: Jones (1982)

O autor afirma que contratos futuros baseados em moedas estrangeiras e em Eurodollars $T D s^{14}$ poderiam ser liquidados tanto por entrega física como por liquidação financeira, visto que apresentam "bons" preços no mercado à vista e boa disponibilidade de oferta. Já Eurodollars $C D s^{15}$ apresentam pouca disponibilidade de oferta, e a liquidação financeira seria a mais adequada. Para

\footnotetext{
${ }_{15}^{14}$ Eurodollars Time Deposits.

${ }^{15}$ Eurodollars Certificate of Deposits.
} 
gado, os contratos futuros não deveriam ser liquidados financeiramente, devido à ausência de preços representativos do mercado à vista.

Adicionalmente, Pirrong et al. (1991) também sugerem que a liquidação financeira é indicada apenas para commodities cujos mercados são centralizados ou então para aquelas cujos mercados, embora descentralizados, apresentam custos de transação relativamente baixos, como por exemplo Eurodollars TDs.

Leuthold (1992) afirma que o principal problema com a liquidação financeira dos contratos futuros de bovinos e suínos, nos Estados Unidos, é a obtenção de informações no mercado, para desenvolver um índice de preços à vista confiável. A maior parte dos animais é vendida particularmente, sem registros públicos e os principais grupos não são observadores autônomos. Eles tomam posições no mercado futuro, o que torna difícil a verificação dos preços. A crescente concentração das indústrias processadoras apenas agrava esse problema. Dados históricos, que poderiam ser úteis para compor um indice, geralmente não estão disponiveis por parte das indústrias processadoras. Além disso, calcular um índice baseado nos valores de carcaça pode gerar problemas similares quanto à confiabilidade e potencial para manipulação, por parte daqueles que detém as informaçōes originais. Nesse caso, a liquidação financeira pode minar o processo de descoberta de preços e tornar a base menos previsível para muitos produtores, elevando o risco do hedging.

A despeito das características apontadas acima para a adoção da liquidação financeira, a mesma foi introduzida, em setembro de 1986, pela Chicago Mercantile Exchange (CME), como forma obrigatória de liquidação do contrato futuro de boi magro. Os motivos principais que levaram a CME a modificar as especificações desse contrato e adotar a liquidação financeira foram (Elam, 1988; Kenyon et al. 1991 e Rich \& Leuthold, 1993): 1) disputas associadas ao padrão da mercadoria a ser entregue; 2) os deságios para as 
mercadorias fora das especificações estavam freqüentemente desalinhados com os diferenciais de preço do mercado à vista; 3) elevados custos de entrega; 4) múltiplos locais de entrega, gerando incerteza dos long hedgers em relação ao local de recebimento da mercadoria; 5) elevado risco de base.

A oferta de lotes irregulares em certos mercados regionais elevavam ainda mais os custos de entrega, que por sua vez ampliavam o risco de base. Conseqüentemente, a efetividade do hedging era reduzida. Além disso, o estabelecimento de múltiplos locais credenciados para entrega se por um lado, reduzia a possibilidade de squeezes, por outro, aumentava a incerteza dos long hedgers quanto ao local de recebimento da mercadoria e aumentava o risco de base, devido às diferenças geográficas de preços.

A determinação das especificações dos contratos futuros é extremamente difícil, mas dela depende o sucesso de um contrato. Se as especificações da commodity e os locais de entrega coincidem com as práticas no mercado físico, o contrato futuro é útil para os participantes do mercado. Caso contrário, esses participantes podem sentir-se desestimulados a utilizar o contrato como instrumento de hedging. 


\section{O CONTRATO FUTURO DE BOI GORDO DA BM\&F}

No Brasil, o boi gordo é negociado em mercados futuros desde 1980, época em que os contratos eram negociados na Bolsa de Mercadorias de São Paulo (BMSP). Em 1980, foram negociados 4.705 contratos, dos quais apenas seis foram liquidados por entrega física, ou seja, apenas $0,13 \%$ do total. Em 1981 , o volume de contratos negociados saltou para 46.592 , sendo que $2,3 \%$ do total representaram entrega efetiva da mercadoria. Nos anos seguintes, o volume de contratos negociados continuou crescendo, atingindo o auge em 1985, quando 230.142 contratos foram transacionados, mas somente 0,35\% deste total foram liquidados por entrega física (BM\&F, 1994). Em setembro de 1986, a expansão do mercado foi bruscamente interrompida pelo Banco Central, que determinou a liquidação compulsória do contrato futuro de boi gordo na BMSP. No mês de novembro, as negociações foram reabertas, mas a atratividade dos investidores por esse mercado foi minada pela intervenção governamental e pela imposição de medidas restritivas, que inviabilizaram o mercado. O ano de 1986 encerrou-se com 162.524 contratos negociados (BM\&F, 1994) e, em abril de 1987, parte das condições restritivas foi revogada pelo Banco Central (BMSP, 1987).

Em janeiro de 1986 foi fundada a Bolsa Mercantil \& de Futuros e já no primeiro levantamento oficial de suas atividades, referente ao período entre 31 de janeiro de 1986 e 31 de julho de 1987, despontou como a maior do país, com $71,5 \%$ do mercado de futuros no Brasil. Então, na tentativa de consolidar o 
mercado futuro de commodities agropecuárias, esta Bolsa lançou, ao longo do ano de 1987, os contratos futuros de frango, boi gordo e porco (Ferreira \& Horita, 1996). Desta forma, a partir de 1987, o boi gordo passou a ser negociado através de contratos futuros tanto na BMSP, como na Bolsa Mercantil \& de Futuros.

Entretanto, durante a segunda metade da década de oitenta, o mercado futuro de agropecuários não se desenvolveu a contento. Nesse período, os programas de ajustamento para o controle da inflação, iniciados em $1986 \mathrm{com}$ - Plano Cruzado, e as perturbações no quadro político do país geraram um cenário de instabilidade na economia brasileira. Houve uma mudança no perfil dos investimentos, com redução do interesse por aplicações financeiras e aumento da busca por ativos reais, dentre os quais a aquisição de gado bovino. Os preços do boi gordo no mercado à vista ficaram distorcidos e, conseqüentemente, a consolidação do mercado futuro deste ativo tornou-se inviável.

A situação presenciada no período levou à retração das negociações do contrato futuro de boi gordo, reduzindo assim a liquidez deste mercado. Todavia, esse contrato continuou sendo negociado na BMSP até 1991. Durante todo esse periodo, as entregas efetivas da mercadoria não ultrapassaram $5 \%$ do volume total negociado (BM\&F, 1994), o que demonstra sua utilização muito mais como instrumento de hedging do que como forma de entrega e recebimento dos animais.

Da mesma forma, sem conseguir alcançar a liquidez desejada, as transações do contrato futuro de boi gordo na Bolsa Mercantil \& de Futuros foram bastante irregulares desde seu lançamento, em 1987, até 1990. Em junho de 1987, foi implantado o Plano Bresser e os contratos negociados de maio a dezembro foram convertidos por um fator de deflação ("tablita") divulgado pelo governo. Durante o ano de 1988, o contrato foi negociado nos meses de abril/maio e novembro/dezembro. O Plano Verão foi adotado pelo 
governo em janeiro de 1989, e nesse ano foram transacionados contratos no mês de janeiro e durante o período compreendido entre abril e outubro. Novamente, para administrar os contratos futuros, a Bolsa aplicou a tabela de conversão publicada pelo governo. Em 1990, foi editado o Plano Collor I, com o qual o governo estabeleceu, entre outras medidas, o bloqueio de cerca de $70 \%$ dos recursos financeiros pertencentes ao setor privado. Com isso, eliminou-se parte da renda financeira e reduziu-se o investimento do setor privado, pois tanto os recursos especulativos quanto os recursos de investimentos que se protegiam da inflação foram bloqueados. Nenhum contrato futuro de boi gordo foi negociado nesse ano. O Plano Collor II, de acordo com Ferreira \& Horita (1996), marcou a ação mais severa do governo contra a Bolsa em dez anos de história. Em janeiro de 1991, o governo mandou liquidar compulsoriamente todos os contratos em negociação na Bolsa Mercantil \& de Futuros e somente depois de um mês as negociações foram retomadas no Pregão.

O mercado agrícola e, por conseguinte, o futuro de commodities agropecuárias, necessitam, mais do que qualquer outra atividade, de regras estáveis para seu desenvolvimento, visto que as decisões de investimento envolvem perspectivas de longo prazo e esse não foi o cenário propiciado pela economia brasileira no período em questão.

Em maio de 1991, a BMSP incorporou-se à Bolsa Mercantil \& de Futuros, originando a Bolsa de Mercadorias \& Futuros (BM\&F). O contrato futuro cambial de boi gordo da BM\&F foi lançado em junho de 1991. Esta versão do contrato estabelecia como objeto de negociação o boi gordo, castrado, bem acabado, com 450 a $550 \mathrm{~kg}$ de peso, idade máxima de 60 meses, cotado em pontos (equivalentes à taxa de câmbio média das operações de compra e venda de dólares americanos) por arroba líquida ${ }^{16}$. Cada contrato

\footnotetext{
${ }^{16}$ O contrato futuro de boi gordo da BM\&F é cambial e sua data de vencimento coincide com a do contrato futuro de dólar, facilitando a fixação do preço em real, quando assim for conveniente.
} 
estabelecia a negociação de 330 arrobas liquidas, estimando-se um rendimento de carcaça de $54 \%$ e $52 \%$, para animais acabados em pasto e em confinamento, respectivamente. Os meses de negociação eram fevereiro, abril, junho, agosto, setembro, outubro, novembro e dezembro. O último dia de negociação e a data de vencimento do contrato eram o sétimo dia útil anterior ao último dia do mês de vencimento. A liquidação do contrato por entrega poderia ocorrer em quatro municípios: Araçatuba (SP), Barretos (SP), Presidente Prudente (SP) e São Paulo (SP). A formação dos lotes deveria ocorrer em propriedades distantes, no máximo, $750 \mathrm{~km}$ do ponto de entrega mais próximo. A corretora de mercadorias deveria emitir ○ Aviso de Entrega do vendedor que formalizasse a intenção de liquidar seus contratos pela entrega. Esse Aviso ficaria disponivel no Pregão do dia, para que as corretoras com clientes na posição comprada, interessados em receber os lotes, pudessem fazer a escolha. Após o término do Pregão, os Avisos de Entrega não escolhidos eram compatibilizados pela BM\&F, seguindo o critério da antigüidade da abertura de posições. $O$ valor de liquidação era o preço de ajuste do dia útil anterior à data de entrega do Aviso, multiplicado pelo peso líquido de cada contrato e pela taxa de câmbio média entre as operações de compra e venda de dólares americanos daquele dia (ver Apêndice 1).

A padronização do contrato é o que possibilita a negociação do boi gordo através do mercado futuro. Devido às características do ativo negociado, as especificações do padrão de qualidade e conduta para entrega são bastante detalhadas. Embora o objetivo dos mercados futuros não seja a entrega da mercadoria, é a possibilidade de que ela ocorra que garante a convergência dos preços à vista e futuro. No caso de animais, as dificuldades apontadas na seção 2.3, referentes à padronização dos lotes para arbitrar mercados e forçar a convergência dos preços à vista e futuro, acabavam ampliando o risco de base desses contratos. 
Apesar de representar uma percentagem bastante pequena do total de contratos negociados (aproximadamente 2\%, de acordo com Bialoskorski Neto, 1994), a entrega e recebimento da mercadoria no vencimento levava a atritos entre compradores e vendedores, decorrentes da dificuldade em adequar todas as especificações do contrato futuro ao mercado físico, visto que as disputas entre compradores e vendedores relacionavam-se à qualidade dos animais, porque 0 vendedor sempre procurava entregar aqueles com os padrões minimos estabelecidos no contrato.

Desta forma, quando do recebimento dos lotes, caso não estivessem em conformidade com as especificações do contrato ou caso houvesse dúvidas quanto à pesagem dos animais, o cliente comprador teria o direito de solicitar arbitramento $^{17}$ à BM\&F, cuja decisão seria final. Os custos da arbitragem corriam por conta da parte perdedora. Todavia, esse procedimento todo tornava morosa a entrega da mercadoria e o encerramento das posições. ${ }^{18}$

Outro problema a ser apontado no procedimento de entrega física é o custo de deslocamento do produto. Os elevados valores do frete para transportar os animais acabam encarecendo a entrega e o stress causado pela viagem ocasiona perda de peso, o que não interessa a nenhuma das partes envolvidas na negociação. ${ }^{19}$

\footnotetext{
${ }^{17}$ Arbitramento é o procedimento pelo qual as partes recorrem ao juizo arbitral da BM\&F, para resolver pendências ou litígios, sem utilização do poder judiciário, conforme estabelecido no Estatuto Social, Regulamentos e Normas da Bolsa (Ferreira \& Horita, 1996).

${ }_{18}$ Após o lançamento, foram realizadas algumas modificações nas especificaçōes do contrato futuro de boi gordo. Em agosto de 1992, houve alteração da data de vencimento e último dia de negociação, que passou a ser o sexto dia útil anterior ao último dia do mês de vencimento. Em outubro de 1993, houve alteração nas condições de liquidação no vencimento, relativa ao pagamento do FUNRURAL. Entretanto, essas mudanças não alteraram o contrato, no que se refere ao mecanismo de entrega física (ver Apêndice 2).

${ }_{19} \mathrm{Na}$ versão do contrato que vigorou até dezembro de 1993, o comprador habilitado a receber a mercadoria, por decisão própria ou escolhido pela posição mais antiga, deveria providenciar a retirada dos animais da fazenda do vendedor. Com as modificações introduzidas a partir de maio de 1994, o vendedor seria responsável pelos custos de colocar o gado no curral credenciado pela BM\&F e o comprador pelos custos de sua retirada ou permanência no local, após o dia da pesagem.
} 
Os atritos entre compradores e vendedores, por causa das especificações relativas ao padrão dos animais, bem como os custos de entrega e recebimento da mercadoria, geram incertezas aos participantes do mercado e dificultam o arbitramento entre os mercados para forçar a convergência dos preços à vista e futuro. É esperado que os preços à vista e futuro tornem-se mais próximos, à medida que se aproxima a data de vencimento do contrato. Assim, a convergência de preços compõe a porção previsível da variação da base e não é considerada risco (Garcia et al., 1984). Porém, uma alteração no mecanismo de convergência, causada por problemas com a entrega física, é uma variação imprevisivel. É, desta forma, que os obstáculos à convergência de preços acabam ampliando o risco de base e aumentando as imperfeições no processo de liquidação.

Poucos agentes permaneciam com suas posiçōes em aberto até 0 vencimento do contrato. Entretanto, quando não conseguiam sair do mercado $e$ tinham de liquidar o contrato por entrega da mercadoria, poderia haver problemas com a distância entre o local de formação do lote e o ponto de entrega, já que esta deveria ocorrer em locais distantes no máximo $750 \mathrm{~km}$ do ponto de entrega mais próximo, o que inviabilizava a participação de agentes de todo o país. Assim, um agente com posição vendida, que não possuísse a mercadoria ou, então, que a possuísse a uma distância além do raio estabelecido para formação dos lotes e não conseguisse sair do mercado até o vencimento, tinha de recorrer à compra de animais em mercados próximos ao ponto de entrega. Desta forma, dependendo do número de agentes na mesma situação, bem como da quantidade de animais a ser adquirida, o preço regional onde seria efetuada a entrega poderia elevar-se, refletindo apenas as condições do mercado local. Por outro lado, o agente com posição comprada, que não conseguisse sair do mercado antes do vencimento e não tivesse como objetivo receber a mercadoria, poderia receber os animais e vendê-los para frigoríficos ou processadores de carne próximos ao local de entrega. 0 mesmo 
poderia ocorrer quando o objetivo era o recebimento da mercadoria, mas a entrega aconteceria em locais distantes do destino final dos animais, pois o valor do frete encarecia o produto e então era preferivel vender os animais e realizar a compra no mercado à vista mais próximo à atividade em questão. Nesse caso, os preços à vista nos mercados regionais próximos aos pontos de entrega poderiam cair, dependendo do volume de animais ofertados.

Nas duas situações descritas acima, o preço à vista nos mercados regionais estava sujeito a flutuações, decorrentes do aumento da oferta ou demanda por animais, nos locais onde ocorreria a entrega, causando uma variabilidade dos preços relativos entre o mercado de entrega e outros mercados comercialmente importantes. Desse modo, o mercado regional poderia não refletir o preço da Bolsa, cuja formação espelha as condições de oferta e demanda dos principais mercados no país. Essa situação amplia o risco de base devido à localização.

Os problemas acima citados acabavam por dificultar a participação de agentes que desejavam utilizar os contratos para assegurar preço, sem o objetivo de entregar ou receber a mercadoria, ou simplesmente para obtenção de lucro no mercado. Especuladores e investidores institucionais, que propiciam liquidez ao mercado, sentiam-se pouco à vontade para operar esse contrato, pois temiam pela possibilidade de não conseguir encerrar suas posições antes do vencimento ou sofrer um corner ${ }^{20}$ nessa data. A baixa liquidez apresentada pelo mercado futuro de boi gordo acabava ampliando o risco de base, pois, segundo Rich (1990), num mercado com pouca liquidez, os preços futuros estão mais sujeitos a oscilações e quanto mais flutuarem esses preços, maior a variação da base e maior seu risco.

Em 11 de março de 1992, o Conselho Monetário Nacional autorizou a constituição dos Fundos de Investimentos em Commodities (FIC), tendo em

\footnotetext{
${ }^{20}$ Corner. compra de uma commodity em volume tão elevado, que faz com que o comprador passe a deter controle sobre os preços (Ferreira \& Horita, 1996).
} 
vista aumentar as operações realizadas nos mercados físico e de liquidação futura de produtos agropecuários e agro-industriais. O Banco Central emitiu circular regulamentando e disciplinando a constituição e o funcionamento desses Fundos, em 24 de julho de 1992 (Amorim, 1994).

Os Fundos de Investimento em Commodities permitiam ao depositante obter liquidez diária de resgate com correção do valor da cota depois dos primeiros trinta dias de aplicação e a rentabilidade seguia a taxa máxima do juro praticado no mercado de troca de dinheiro entre instituições financeiras por um dia (CDI). Devido a tais características, esta modalidade de investimento tornou-se sucesso entre a população (Ferreira \& Horita, 1996).

A carteira dos FIC deveria ser composta por no mínimo 10\% de posições em mercados organizados de liquidação futura, envolvendo contratos referenciados em produtos agropecuários e agro-industriais ${ }^{21}$. Todavia, os mercados futuros de agropecuários possuíam ainda baixa liquidez e a possibilidade de não conseguir encerrar as posições até a data do vencimento poderia culminar com a entrega ou recebimento da mercadoria. Uma vez que esta não era a intenção desses Fundos, sua participação ficou restrita às operações em posições travadas com opções sobre futuros de café $\left(B o x^{22}\right)$.

Tendo em vista os problemas ocasionados pela entrega física, a estratégia elaborada pela BM\&F era composta de duas medidas para aprimorar o contrato futuro de boi gordo. A primeira, de curto prazo, era o estabelecimento de um único local para entrega da mercadoria, visando reduzir os custos e problemas operacionais relacionados aos diversos locais de entrega e formação de lotes. A segunda, de médio prazo, era a introdução da liquidação financeira para o contrato futuro de boi gordo. Esta medida só era

${ }^{21}$ De acordo com Staduto (1995), foram definidos como contratos negociados em mercado organizado de liquidação futura, aqueles enquadrados nas modalidades operacionais "a termo", "futuro" ou "opções ", negociados regularmente nas Bolsas de Valores ou Mercadorias e de Futuros, aprovados pelo Banco Central ou pela Comissão de Valores Mobiliários.

${ }^{22}$ Box: negociação simultânea, em Pregão, de opção de compra e de opção de venda, ambas envolvendo os mesmos preços de exercício e vencimentos (Ferreira \& Horita, 1996). 
possível a médio prazo, porque para adotá-la era necessário a elaboração de um índice que representasse o preço do boi gordo no mercado à vista. A adoção de um índice para liquidar os contratos também era vista como forma de atrair os Fundos de Investimento em Commodities para o mercado futuro de boi gordo (Frick, 1997) ${ }^{23}$. Contudo, em setembro de 1995, o governo viria a extinguir essa modalidade de aplicação, visando alongar os prazos de investimento da economia.

Em maio de 1994, a BM\&F abriu à negociação o contrato futuro de boi gordo com as alterações de curto prazo, objetivando aprimorar o sistema de entrega física. Essa nova versão do contrato determinava que a formação dos lotes poderia ter origem em qualquer lugar do pais, mas a entrega dos animais deveria ocorrer em currais credenciados pela Bolsa, estabelecidos no município de Araçatuba (SP). A pesagem dos animais, que antes era feita em balança escolhida pelo vendedor, passou a ser feita pelo curral credenciado, em balança da BM\&F. Para isso, os animais deveriam chegar ao curral no dia anterior ao da pesagem, até as 22 horas, podendo ser reidratados. A pesagem seria realizada no dia seguinte, por ordem de chegada. $O$ rendimento de carcaça para cálculo do peso líquido também foi alterado: passou a ser função apenas do peso bruto do animal e não mais do regime de engorda ${ }^{24}$. Os animais fora das especificações sofreriam deságio sobre o valor total. A data de vencimento do contrato e último dia de negociação passaram a ser o décimo quinto dia útil do mês de vencimento e os meses de negociação passaram de oito para cinco, a saber: março, maio, agosto outubro e dezembro (ver Apêndice 3). Simultaneamente à implementação destas mudanças, a BM\&F formalizou um convênio com a Escola Superior de Agricultura "Luiz de Queiroz"

\footnotetext{
${ }^{23}$ Oscar Frick (Bolsa de Mercadorias \& Futuros). Comunicação pessoal, 1997.

$24 \mathrm{O}$ peso líquido de cada animal era estabelecido em $52 \%$ do peso bruto para animais com peso entre 450 e 470 quilos, $53 \%$ do peso bruto para animais com peso entre 471 e 490 quilos, $54 \%$ do peso bruto para animais com peso entre 491 e 550 quilos.
} 
(ESALQ) para a elaboração de um indicador de preços, que representasse o preço do boi gordo no mercado à vista no Estado de São Paulo.

As mudanças adotadas pela Bolsa visavam reduzir ainda mais o volume de entregas e ao mesmo tempo agilizar a comercialização pela pesagem dos animais em balança da BM\&F. Além disso, esperava-se que a formação de preços em um único local fornecesse mais transparência ao mercado, elevando o volume de negócios (BM\&F, 1994). Contudo, essas modificações não foram suficientes para solucionar os problemas decorrentes da liquidação por entrega física e aumentar a liquidez do mercado. Em 1993, o número de contratos transacionados havia sido 7.438 e, em 1994, caiu para 5.687 (Resenha BM\&F, 1993 e 1994).

Uma vez que o Indicador de Preço Disponível do Boi Gordo ESALQ/BM\&F (IBG) vinha sendo calculado e divulgado ao público desde março de 1994, em 12 de dezembro do mesmo ano, a BM\&F informou ao mercado as alterações e novas especificações para o contrato futuro cambial de boi gordo, que entrariam em vigor a partir do vencimento agosto de 1995. Esse contrato foi aberto à negociação no dia 16 de dezembro de 1994 e as principais modificações em relação à versão anterior foram: 1) só haverá entrega física quando ambos, compradores e vendedores, manifestarem essa intenção, e houver compatibilização entre contratos de compra e venda; 2) os contratos futuros que permanecerem até o dia do vencimento serão liquidados financeiramente com a utilização da média aritmética dos cinco últimos dias úteis do IBG ESALQ/BM\&F no mês de vencimento; 3) a taxa de câmbio utilizada passa a ser a de venda e não mais a média de compra e venda; 4) o rendimento do peso bruto apurado do boi passa a ser $54 \%$, em vez da tabela relacionando peso bruto com rendimento de carcaça, com deságios para pesos brutos fora da especificação (ver Apêndice 4).

Assim, a liquidação no vencimento pode ser financeira ou pela entrega física, se for o desejo de ambas as partes, vendedores e compradores. Caso os 
detentores das posições comprada e vendida decidam pela liquidação física, devem comunicar às corretoras entre o quinto e o penúltimo dia útil do mês (véspera do vencimento do contrato). A Bolsa concilia as intenções de liquidação e informa os interessados no dia seguinte ao vencimento. $A$ data da entrega é combinada entre as partes e deve ser comunicada à BM\&F com dois dias de antecedência. A entrega deverá ocorrer em Araçatuba (SP), único local credenciado pela Bolsa para entrega da mercadoria. Entretanto, a maior parte dos contratos não é liquidada por entrega física, mas por liquidação financeira. As posições em aberto após o Pregão do último dia de negociações são encerradas assumindo-se posições contrárias às detidas, cujo preço é definido pela média aritmética dos cinco últimos Indicadores de Preço Disponível do Boi Gordo ESALQ/BM\&F.

De acordo com a BM\&F, as principais vantagens proporcionadas pelas modificações promovidas seriam: 1) o Indicador fornece uma maior eqüidade de preços, tanto para vendedores como para compradores; 2) o conceito de hedging aplica-se ao preço da mercadoria e não à entrega física; 3) participantes de todo o país podem integrar esse mercado; 4) a diferença de tributação entre Estados e possiveis distorções causadas por ela não devem comprometer o uso deste instrumento de hedging; 4) a liquidação feita pela média dos cinco últimos Indicadores dificulta a distorçāo de preços no vencimento; 5) uma vez que os contratos serão liquidados por diferença, envolvendo o mercado físico somente em casos especiais, os participantes sentem-se mais estimulados a integrar o mercado, aumentado a liquidez dos contratos e tornando-os mais úteis tanto para os hedgers como para os especuladores (BM\&F) ${ }^{25}$.

${ }^{25}$ Bolsa de Mercadorias \& Futuros. Conhecendo o novo procedimento de liquidação do contrato de boi gordo referenciado no indicador de preço ESALQ/BM\&F: Informativo, São Paulo, 1994. 
$\mathrm{Na}$ verdade, as vantagens apontadas pela Bolsa, advindas da introdução da liquidação financeira, trazem implícitas a possibilidade de redução do risco de base. $O$ encerramento das posições no vencimento através de um índice que represente uma média dos preços no mercado à vista (IBG ESALQ/BM\&F), deve levar à redução no risco de base porque se espera que a média dos preços em diversos mercados regionais varie menos do que o preço do animal com padrões mínimos para entrega em cada mercado. Adicionalmente, esperase que variando menos, a base se torne mais previsivel, reduzindo o risco e melhorando a performance do hedging (Jones, 1982; Garbade \& Silber, 1983 e Paul $^{26}$, citado por Hsiang \& Lien, 1996).

Uma vez que não há entrega física, os custos referentes a este procedimento e os atritos entre compradores e vendedores por causa das especificações dos animais são eliminados, reduzindo as incertezas dos participantes do mercado. Além disso, a convergência dos preços à vista e futuro durante o mês de vencimento não é prejudicada, pois esta é imposta pelo preço de liquidação igual ao índice de preço no mercado à vista na data de vencimento do contrato e o risco de base que surge devido a este problema deixa de existir (Garbade \& Silber, 1983). O aumento da liquidez no mercado futuro, propiciado pela participação de agentes que têm restrições para negociar o produto no mercado físico, pode diminuir o risco de base, na medida em que se espera que o maior volume de contratos negociados reduza a volatilidade dos preços futuros (Rich, 1990).

O IBG é um indicador diário de preço do boi gordo no Estado de São Paulo. "Ele é uma média ponderada dos preços nas principais regiões produtoras, a saber: Araçatuba, Bauru/Marília, Barretos/São José do Rio Preto e Presidente Prudente. Os preços da arroba do boi gordo são coletados diariamente, em um grande número de fontes, em cada uma destas regiões, bem como em estados pecuaristas adjacentes, para monitorar a qualidade das

${ }^{26}$ Paul, op. cit., p.23. 
informações do Indicador. As escalas de abate são também levantadas e acrescidas ao prazo de pagamento. Então, os preços com os referidos prazos de pagamento são trazidos para valor presente pela taxa média de desconto das Notas Promissórias Rurais dos principais bancos que operam esta modalidade de negócio. Com os preços à vista obtidos por este procedimento, calcula-se uma média ponderada por região. O critério de ponderação é o da importância de cada região nos abates sob controle do Serviço de Inspeção Federal (SIF). Os pesos que compõem a média ponderada dos preços, são também uma média ponderada mensal dos últimos três anos dos abates sob controle do SIF de cada região, com pesos maiores para os anos mais recentes. Desta forma, obtém-se um painel mensal de ponderação, que permite captar a sazonalidade da atividade. Os preços médios à vista de cada região são agregados através da ponderação descrita, obtendo-se o preço à vista ponderado no Estado de São Paulo. Este preço é convertido em dólares americanos pela taxa de câmbio de fechamento diária de venda e assim é obtido o IBG ESALQ/BM\&F" (BM\&F) ${ }^{27}$.

Em novembro de 1996, a BM\&F abriu para negociação os meses de janeiro, março e maio, de forma que todos os meses do ano passaram a ser cotados. As mudanças implementadas pela BM\&F, desde o lançamento do contrato, demonstram a necessidade e o desejo de adequá-lo aos agentes do mercado, visando aprimorar a performance do hedging e torná-lo mais útil como mecanismo de garantia de preço.

${ }^{27}$ Bolsa de Mercadorias \& Futuros, op. cit., p.38. 


\section{REVISÃO DE LITERATURA}

Depois que a Chicago Mercantile Exchange (CME) introduziu a liquidação financeira para o contrato futuro de boi magro, alguns estudos foram conduzidos para verificar o impacto da mesma sobre a variabilidade da base. Inicialmente, a Commodity Futures Trading Commission (CFTC) analisou o impacto desta sobre a variabilidade da base para contratos de animais machos, pesando de 600-800 libras, em Oklahoma City, de setembro de 1986 a maio de 1987. Oklahoma City representa apenas um mercado dentre os 27 estados incluídos no cálculo do índice utilizado para liquidação financeira de animais machos pesando de $600-800$ libras $^{28}$. A CFTC concluiu que a variabilidade da base havia sido reduzida para Oklahoma City, imediatamente após a introdução da liquidação financeira e que isso provavelmente ocorreria nos demais mercados. Contudo, a existência de muitos centros de comercialização e de diversos tipos de animais tornava necessário o desenvolvimento de pesquisas futuras (Kenyon et al., 1991 e Leuthold, 1992).

De fato, posteriormente, diversas pesquisas foram desenvolvidas, a fim de verificar o impacto da introdução da liquidação financeira para os contratos futuros de boi magro da CME. Kilcollin ${ }^{29}$, citado por Elam (1988), afirmou que

\footnotetext{
${ }^{28} \mathrm{O}$ índice utilizado para liquidação dos contratos futuros de boi magro da CME era o United States Feeder Steer Price (USFSP). Este índice é uma média ponderada dos preços de animais machos, com 600-800 libras, para 4 regiões dos Estados Unidos, incluindo 27 estados. A ponderação é feita pelo número de animais em cada região, em $1^{\circ}$ de janeiro de cada ano (Schroeder \& Mintert, 1988).

${ }^{29}$ KILCOLLIN, T.E. Carta a Jean A. Webb, Commodity Futures Trading Commission, de Kilcollin, vice-presidente, Chicago Mercantile Exchange, Jan., 1985.
} 
"uma pesquisa conduzida pelo Cattle-Fax ${ }^{30}$ e pela Chicago Mercantile Exchange indicou que, com a introdução da liquidação financeira, o risco de base foi reduzido para animais machos pesando de 600-800 libras, em 27 estados". A fim de estender esses resultados para faixas de pesos mais leves e para animais fêmeas, Elam (1988) analisou se haveria redução no risco do hedging, pela introdução da liquidação financeira, para o contrato futuro de boi magro da $\mathrm{CME}$, em comparação com a entrega física. Foram considerados na análise preços para machos e fêmeas de estrutura média, pesando 300-400, 400-500, 500-600, 600-700 libras. O período de análise foi 1977 a 1986 e consideraram-se os contratos futuros para os meses de janeiro, março, abril, maio, agosto, setembro, outubro e novembro.

Foi desenvolvida uma expressão para medir o risco do hedging baseado em uma amostra de preços à vista e futuro. Foram utilizados os preços à vista de Arkansas, pois além deste representar um dos maiores mercados, há também um alto grau de correlação entre os preços ali praticados e os dos demais mercados. Os preços futuros utilizados para os contratos liquidados por entrega física foram os da CME e os preços do Cattle-Fax prestaram-se para representar os preços futuros sob liquidação financeira, pois durante o período considerado (1977 a 1986) existia somente a liquidação por entrega física.

Os resultados obtidos pelo autor indicaram que o risco do hedging estimado, considerando-se a liquidação financeira, foi menor, quando comparado com a entrega física, para machos e fêmeas com peso entre 600700 libras. Uma vez que a maior parte das operaçōes de hedge, utilizando o contrato futuro de boi magro, é feita para animais com mais de 600 libras, a redução no risco do hedging devido à introdução da liquidação financeira deveria resultar numa maior utilização comercial dos contratos futuros de boi magro. Para os animais com menos de 600 libras, os resultados indicaram que

${ }^{30}$ Cattle-Fax é uma seção de difusão de informações da National Cattlemen's Association (Rich, 1990). 
o risco do hedging estimado, considerando-se liquidação financeira, foi menor para as operações de hedge de outono, enquanto que, para as de primavera, o risco aumentou.

Nesse trabalho, simulou-se a liquidação financeira dos contratos futuros de boi magro, assumindo-se que os preços futuros para liquidar financeiramente os contratos eram iguais às séries históricas de preços do mercado à vista (United States Feeder Steer Price - USFSP). Assim, Elam (1988) tentou estimar qual teria sido a variabilidade da base em determinado período se houvesse a possibilidade de liquidar os contratos financeiramente e compará-la com a variabilidade da base dos contratos com entrega física no mesmo período. Por isso, como os resultados foram baseados em preços simulados, os mesmos somente se mantém válidos se a relação entre os preços utilizados para simular a liquidação financeira e os preços futuros for a mesma depois da sua introdução.

Outro ponto a ser observado é que a mudança realizada pela CME no contrato futuro de boi magro não foi somente em relação à adoção da liquidação financeira, mas trouxe também modificações nas especificações. Além de as faixas de peso terem sido alteradas de 575-700 libras para 600-800 libras, outras mudanças menores foram implementadas (Schroeder \& Mintert, 1988). Ao proceder-se a análise somente com dados do período anterior à introdução da liquidação financeira (dados simulados), obtêm-se resultados que não refletem essas alterações. Assim, dados do período posterior à sua introdução são importantes, porque as novas especificações dos contratos podem afetar os níveis médios da base e seus padrões de comportamento. Portanto, a análise desses dados abrange tanto o impacto da introdução da liquidação financeira, quanto o das mudanças nas especificações do contrato sobre o risco de base. 
Schroeder \& Mintert (1988) analisaram a mudança na razão de hedge ${ }^{31}$ e compararam o risco do hedging para a liquidação física e para a liquidação financeira. Os autores utilizaram o método proposto por Elam (1988), considerando porém, quatro mercados: Amarillo, Dodge City, Kansas City e Illinois Direct. Os três primeiros representam os maiores mercados incluídos no cálculo do USFSP e o último representa o maior mercado não incluído neste cálculo.

Nesse estudo, foram utilizados os preços à vista desses mercados, os preços futuros da CME sob liquidação física e uma série histórica do USFSP para representar os preços futuros sob liquidação financeira, uma vez que ainda não havia dados disponíveis para análise. O período analisado foi de janeiro de 1977 a dezembro de 1987. As categorias de animais (machos e fêmeas) incluídas foram 300-800 libras, com subclasses a cada incremento de 100 libras (300-400, 400-500, 500-600, 600-700, 700-800).

A expressão para medir o risco do hedging foi calculada usando os preços para entrega física e posteriormente usando a série histórica do USFSP. A comparação dos resultados obtidos levou à conclusão de que o risco do hedging sob liquidação financeira, utilizando o USFSP para representar os preços futuros, foi geralmente menor do que para entrega física. A redução no risco do hedging foi maior para animais que se enquadravam nas especificações dos contratos. Quanto à razão de hedge, os resultados sugeriram um aumento de 10 para 15\%, considerando-se a liquidação financeira. Os autores concluíram que a adoção da liquidação financeira levaria, geralmente, a uma redução no risco do hedging e esta, a uma maior utilização dos contratos futuros de boi magro da CME.

Da mesma forma que no trabalho de Elam (1988), os dados utilizados no estudo de Schroeder \& Mintert (1988) são para o período anterior à introdução

\footnotetext{
${ }^{31}$ A razão de hedge é definida como a proporção da posição à vista que é coberta por posições opostas em vencimentos futuros.
} 
da liquidação financeira e embora a análise inclua um número maior de mercados, os resultados mantêm-se válidos apenas se a relação entre o índice utilizado para representar a liquidação financeira (USFSP) e os preços futuros for a mesma depois da sua introdução. Além disso, os resultados não refletem as modificações nas especificações do contrato, introduzidas juntamente com a liquidação financeira, porque os dados utilizados na análise referem-se apenas ao período anterior a esta.

Novas pesquisas foram surgindo, adicionando aos estudos já existentes, análises envolvendo outros mercados. Assim, Kahl et al. (1989) apontaram em seu estudo que uma pesquisa informal realizada com participantes do mercado de gado, indicou alguns problemas com as especificações do contrato futuro de boi magro da $\mathrm{CME}$ :

1) imprecisão na entrega da mercadoria especificada em algumas regiões, o que levava a transportar o gado para locais onde esta imprecisão era menor; 2) o contrato servia historicamente de base para entrega do gado de baixa qualidade;

3) alguns pontos de entrega, localizados fora das principais áreas de criação, exerciam impactos adversos nos preços futuros e aumentavam a incerteza dos long hedgers em relação ao local de entrega;

4) as especificações do contrato vigente não permitiam que algumas raças de animais economicamente importantes fossem entregues e o tamanho do contrato não estava adequado às negociações no mercado físico.

0 aparente sucesso da liquidação financeira em reduzir o risco de base para o contrato futuro de boi magro da $\mathrm{CME}$ e, ao mesmo tempo, os problemas apontados pela pesquisa citada por Kahl et al. (1989), levaram os autores a examinar se a introdução da liquidação financeira realmente promoveu melhorias no contrato. Os autores relacionaram três critérios a serem satisfeitos para que a liquidação financeira promovesse melhoria nos contratos futuros: 1) a mudança para a liquidação financeira deveria fazer com que a 
variabilidade da base diminuísse; 2) o preço à vista utilizado para a liquidação deveria representar adequadamente o valor de mercado; 3) ० potencial para manipulação do preço utilizado para a liquidação financeira deveria ser pequeno.

Para verificar a mudança na variabilidade da base, os autores compararam as variâncias da base vigente para mercados selecionados (California, Arizona, Nebraska, lowa, Colorado, Western Kansas, Eastern Kansas, Texas-Oklahoma) na maturidade do contrato com as variâncias estimadas da base (supondo que os contratos futuros tivessem liquidação financeira baseada em vários índices de preços à vista). Os dados utilizados referem-se ao período de janeiro de 1980 a dezembro de 1986.

Foram útilizados sete indices diários diferentes para representar o índice de liquidação financeira. A base simulada supondo liquidação financeira foi calculada como o preço à vista vigente em cada localização menos o índice de preço considerado, ambos medidos no último dia de transações dos contratos futuros. A base, considerando-se entrega física, foi calculada de duas formas: 1) preço à vista vigente em cada localização menos preço futuro, ambos no último dia das transações de cada contrato; 2) preço à vista vigente em cada localização no último dia das transações menos a média dos preços futuros nos dez últimos dias de transações.

Apenas um dos sete índices testados como índice simulado para liquidação financeira reduziu consistentemente a variabilidade da base para todos os mercados. Foi o "Cattle-Fax Six State Index", um indice que representa o preço dos animais nas maiores áreas de criação dos Estados Unidos, calculado a partir do preço à vista nos Estados de lowa, Nebraska, Kansas, Colorado, Oklahoma e Texas. Assumindo que esse índice tenha sido utilizado para a liquidação financeira, a variância estimada da base simulada foi menor do que a variância da base com entrega física, para todos os mercados considerados. Portanto, se a liquidação financeira tivesse sido 
adotada para liquidar os contratos pelo Cattle-Fax Six State Index durante o período considerado, o risco de base teria sido reduzido.

Contudo, cabe aqui mais uma vez a observação feita aos estudos anteriores, de que como os resultados são baseados em preços futuros simulados, os mesmos somente se mantêm válidos se a relação entre os índices utilizados para simular a liquidação financeira e os preços futuros for a mesma depois da sua introdução. Adicionalmente, os resultados não refletem as demais mudanças efetuadas no contrato por ocasião da introdução da liquidação financeira, uma vez que os dados do período anterior a ela permitem apenas a simulação dos preços futuros sob condição de liquidação financeira e não simular as demais alterações efetuadas no contrato.

Foram apontados alguns problemas quanto à representatividade do Cattle-Fax Six State Index: 1) os preços poderiam não ser representativos, uma vez que a média da faixa de preços diários poderia ser influenciada significativamente por uma venda a preços extremamente altos ou baixos; 2 ) as informações de preços do United States Department of Agriculture (USDA) foram complementadas com informações de preços dos membros do CattleFax, mas apenas os preços de venda foram coletados e os compradores não foram contatados para confirmar o valor; 3) os preços e procedimentos para obtenção dos mesmos não estavam disponíveis ao público; 4) procedimentos diferentes foram utilizados no levantamento dos preços para boi magro e para boi gordo. No primeiro caso, vendedores e compradores informaram os preços, enquanto que no segundo, apenas os vendedores o fizeram. Espera-se, assim, que informações coletadas de compradores e vendedores sejam mais representativas, uma vez que seus interesses são conflitantes. Além disso, como quase todo volume de boi gordo é comercializado diretamente entre compradores e vendedores, as informações não estão disponiveis publicamente. Já para boi magro, como a maior parte é comercializada em 
leilões, o preço é divulgado ao público, o que aumenta a confiabilidade e representatividade dos valores coletados.

Como a introdução da liquidação financeira e as modificações no contrato ocorreram em setembro de 1986, novos dados tornaram-se disponiveis para análise com o passar do tempo e mais trabalhos envolvendo outros mercados foram realizados.

Rich (1990) desenvolveu modelos empíricos para identificar e explicar a variação da base para boi magro, antes e depois da introdução da liquidação financeira, nos contratos futuros da CME, em mercados selecionados nos Estados Unidos. Para isso, quatro métodos foram empregados na pesquisa, a saber: 1) cálculo da variabilidade da base mensal, semanal e diariamente, antes e depois da introdução da liquidação financeira, a fim de detectar a sensibilidade da mudança estrutural no comportamento da base; 2) análise de regressão para isolar a influência da liquidação financeira sobre a variabilidade da base, de outras variáveis explanatórias; 3) modelos de regressão para distinguir a sazonalidade da base e verificar a variabilidade mais detalhadamente para mercados específicos; 4) modelos de explanação da base foram estimados antes e depois da introdução da liquidação financeira para uma melhor compreensão da origem do risco de base e para verificar se a mudança na forma de liquidação afetou o comportamento das variáveis econômicas, em função das quais expressou-se a base.

O período de análise compreendeu dois anos antes da introdução da liquidação financeira (janeiro de 1984 a agosto de 1986) e dois anos depois (setembro de 1986 a junho de 1988). Devido à indisponibilidade de dados, somente 27 de 43 mercados à vista foram considerados no estudo. Da mesma forma, os preços à vista disponiveis para a análise ficaram restritos a animais (machos e fêmeas) pesando entre 600-700 libras.

Para verificar se houve mudança estrutural no comportamento da base pela introdução da liquidação financeira, foram realizados testes para a 
variabilidade da base. A base foi calculada somente para os meses de vencimento dos contratos (janeiro, março, abril, maio, agosto, setembro, outubro e novembro). Assim, foram utilizados 21 contratos antes e 15 depois da mudança na forma de liquidação. A variabilidade foi medida como a variância da amostra da base.

Para as diferentes formas de cálculo da base (mensal, semanal e diária), testou-se a hipótese nula de que sua variância antes da introdução da liquidação financeira seria maior do que sua variância depois, contra a hipótese alternativa de que as variâncias nos dois periodos seriam iguais. Foi testado um par de variâncias para cada mercado e para cada sexo, através da estatística "F".

Os resultados para a variabilidade mensal da base indicaram que o risco do hedging foi reduzido em $89 \%$ dos casos. Os testes para a variabilidade semanal da base na semana que incluía a data de vencimento do contrato mostraram que a variância da base foi reduzida em 44 dos 53 pares de variâncias testados.

Cabe observar que o autor representou o risco de base pela sua variância que foi calculada mensal, semanal e diariamente no mês de vencimento do contrato. Contudo, considera-se risco apenas os movimentos aleatórios da base. Quando a variância é calculada com os valores da base durante o mês de vencimento, ela não representa adequadamente o risco de base, pois levam-se em conta os movimentos de convergência entre os preços à vista e futuro, que compõem a porção previsível de variação da base. 0 mesmo não ocorreu com o cálculo da variância semanal da base que levou em conta a média da base apenas na semana de vencimento do contrato, quando, em geral, a convergência dos preços já ocorreu.

Adicionalmente, Rich (1990) analisou o volume negociado para verificar a suposição intuitiva de que com a redução do risco do hedging, após a introdução da liquidação financeira, o volume transacionado aumentaria. Os 
resultados mostraram um aumento de $65 \%$ no volume negociado, de 1986 para 1988. Este aumento sustenta o argumento de que a liquidação financeira parece ter reduzido o risco do hedging.

Para isolar o efeito da liquidação financeira sobre o risco de base, foram estimados dois modelos de regressão para a variabilidade mensal da base no mês de vencimento do contrato. No primeiro, a variância mensal da base (calculada anteriormente) foi expressa em função da média mensal do preço à vista e de variáveis binárias para sexo, liquidação financeira e localização e, no segundo, a variância foi expressa em função das mesmas variáveis, porém as variáveis para localização foram substituidas por uma variável para distinguir mercados incluídos no cálculo do índice de liquidação financeira daqueles não incluídos.

Os sinais das variáveis obtidos nas duas estimações apresentaram-se conforme o esperado. A liquidação financeira foi significativa e apresentou sinal negativo, indicando que o risco de base diminuiu após sua introdução. A variável sexo apresentou sinal positivo, confirmando estudos anteriores citados pelo autor (Elam, 1988 e Kenyon, 1988 ${ }^{32}$ ), mas não foi significativa. Na primeira estimação, cujo modelo incluiu as variáveis binárias para localização, seus sinais foram diversos e apenas 6 foram significativos. Na segunda estimação, cujo modelo incluiu a variável para distinguir mercados incluídos no cálculo do índice de liquidação financeira daqueles não incluídos, seu sinal foi positivo e significativo, indicando que o risco de base é maior para os mercados não incluídos no cálculo do índice do que para os demais.

Para verificar a variabilidade da base em mercados específicos, estimouse um modelo de regressão para a variabilidade da base na semana que incluia a data de vencimento do contrato, para cada um dos seis mercados

${ }^{32}$ KENYON, D. Impact of cash settlement on Virginia fall feeder cattle basis. In: ANNUAL MEETING OF THE AMERICAN AGRICULTURAL ECONOMICS ASSOCIATION, 1988. Paper. 1988. 
selecionados (Oklahoma City Auctions, Amarillo Auctions, Kansas City Terminal, Kentucky Terminal, Shasta Auctions e Virginia Auctions) e para cada sexo separadamente. A variabilidade semanal da base foi calculada em relação às bases semanais dentro do mês de vencimento do contrato. A variabilidade da base foi estimada em função de uma variável binária para liquidação financeira, da média mensal dos preços à vista na semana de vencimento do contrato, da média do número de contratos em aberto no mês de vencimento e de variáveis binárias para representar os meses de vencimento.

$O$ autor representou o risco de base pela sua variância nas semanas incluídas nos meses de vencimento dos contratos. Contudo, essa forma de cálculo da variância considera a convergência dos preços à vista e futuro e não representa corretamente o risco de base que, conceitualmente, se refere somente à variação de seu componente aleatório.

Os resultados da regressão da variabilidade da base na semana que incluía a data de vencimento indicaram que o risco de base foi menor para contratos sob liquidação financeira. A sazonalidade foi detectada e o sinal para o volume de contratos em aberto foi positivo, ao contrário do esperado. Supunha-se que o sinal da variável volume de contratos em aberto fosse negativo, pois à medida em que ele diminui, espera-se que os preços futuros tornem-se mais voláteis. Também a média mensal dos preços à vista apresentou um sinal contrário ao esperado, geralmente negativo e significativo em $30 \%$ dos casos.

A fim de identificar os fatores que afetam os movimentos da base, o autor estimou modelos para explicá-la. Expressou-se a base em função de variáveis econômicas que afetam oferta e demanda atuais e esperadas. Devido a problemas de correlação entre variáveis, dois modelos foram especificados. No primeiro, a base foi expressa em função da razão entre o preço do boi magro e o preço do boi para abate, da razão entre o número de animais com menos de 500 libras e o número de animais com peso entre 500 e 700 libras e 
de uma variável binária para identificar se houve mudança na razão de preços, após a introdução da liquidação financeira. No segundo, expressou-se a base em função das mesmas razões de preço e número de animais do primeiro modelo, só que a variável binária foi colocada para identificar a mudança na razão do número de animais, após a introdução da liquidação financeira.

Foi utilizada a base mensal para o período compreendido entre janeiro de 1984 e maio de 1988 e, a fim de analisá-la não somente nos meses de entrega, ela foi calculada também para três e seis meses antes do mês de vencimento do contrato. Foram especificados dois modelos para a base e as regressões estimadas para seis mercados (Oklahoma City, Amarillo, Kansas City, Kentucky, Shasta e Virginia) para machos e fêmeas.

Os resultados indicaram que todas as variáveis foram significativas nos dois modelos especificados. O modelo utilizando a base no mês de vencimento do contrato explicou uma proporção muito maior da base do que os modelos com a base calculada três e seis meses antes do vencimento, indicando que é mais difícil explicar o comportamento da base em períodos anteriores ao mês de vencimento. Além disso, as variáveis binárias representando a mudança na razão de preço e de quantidade de animais foram positivas e significativamente diferentes de zero, indicando que a liquidação financeira afetou 0 comportamento das relações.

Para verificar se o nivel médio da base foi alterado pela introdução da liquidação financeira, estimou-se um modelo de regressão da base contra uma variável binária para representá-la, para os seis mercados selecionados na análise anterior. Da mesma forma, a base mensal foi analisada para o mês de vencimento do contrato, para três e seis meses anteriores a ele, para machos e fêmeas. Os resultados indicaram que o nível médio da base aumentou após a introdução da liquidação financeira. Os coeficientes ajustados da regressão da base contra liquidação financeira foram bastante próximos aos das regressões de explanação da base em função das variáveis econômicas, significando que 
a liquidação financeira explica a maior parte da mudança na base e não estas últimas variáveis.

Kennyon et al. (1991) argumentaram que uma melhor performance do hedging depende da capacidade de prever a base no vencimento do contrato futuro. Assim, o hedging será melhor executado quanto melhor for a previsão da base, ou seja, quanto menor for a variância de seu erro de previsão. Uma redução na variância da base não implica numa melhor capacidade de prevêla, pois a variância do seu erro de previsão relaciona-se à base esperada para o momento em que este é finalizado, enquanto a variância da base relacionase à sua média histórica.

Para verificar se a variabilidade da base e a variância de seu erro de previsão foram reduzidos pela introdução da liquidação financeira no contratos futuros de boi magro da CME, dois conjuntos de dados foram utilizados na análise de Kenyon et al. (1991). O primeiro incluiu médias semanais de preços à vista de Oklahoma City (incluído no cálculo do USFSP) e Southwest Virginia (não incluido no cálculo do USFSP) e as médias semanais dos preços futuros, ambos na semana que incluía a data de vencimento dos contratos para o cálculo da base. O período considerado antes da introdução da liquidação financeira foi de janeiro de 1984 a agosto de 1986 e depois de setembro de 1986 a abril de 1989. Somente preços de animais do sexo masculino, de estrutura média e com 600-700 e 700-800 libras, incluídos nas especificaçōes de peso do USFSP, foram levados em conta. O segundo conjunto de dados consistiu-se de preços coletados em 16 mercados individuais na Virginia e de preços futuros de liquidação dos contratos, de março de 1983 a outubro de 1988.

Utilizando-se o primeiro conjunto de dados, foi calculada a variância da base para os períodos anterior e posterior à introdução da liquidação financeira e realizou-se um teste de igualdade de variâncias, através da estatística " $F$ ", para verificar se a introdução da liquidação financeira afetou o risco de base. 
Para Oklahoma City e Southwest Virginia, os resultados encontrados mostraram que o desvio padrão da base foi de 3 a 14\% menor depois da introdução da liquidação financeira, embora essa diferença não tenha sido significativa.

O segundo conjunto de dados foi utilizado para estimar equações para prever a base, antes e depois da introdução da liquidação financeira. A base foi calculada como o preço médio de venda dos lotes de animais com as mesmas características (na mesma data), em cada mercado da Virginia considerado no estudo, menos o preço futuro do contrato com vencimento mais próximo, até o décimo quarto dia do mês de entrega. As datas das vendas dos animais nesses mercados estão concentradas nos meses de março, abril, setembro e outubro. Expressou-se a base em função das variáveis raça, sexo, peso, classificação e estação do ano. A base estimada pela regressão foi subtraída da base vigente na data considerada para determinar o erro de previsão. As somas de quadrados dos resíduos antes e depois da introdução da liquidação financeira foram testados através da estatística " $F$ ", para verificar se esta afetou a variância do erro de previsão da base.

Os resultados mostraram que a variância do erro de previsão da base não diminuiu depois da introdução da liquidação financeira, em comparação ao período em que só havia entrega física. Desta forma, os autores concluíram que o risco de base não foi reduzido para os hedgers de gado na Virginia, como resultado da introdução da liquidação financeira e que, portanto, a redução histórica da variabilidade da base não reduz necessariamente a variância do seu erro de previsão em mercados individuais.

$\mathrm{Na}$ análise de Kenyon et al. (1991), como na de Rich (1990), foram utilizados dados pré e pós introdução da liquidação financeira. Kenyon et al. (1991) afirmaram que a adoção da liquidação financeira promoveu mudanças na relação dos preços à vista e futuro e, portanto, assumir que esses preços são iguais (como nas simulações) não seria adequado, exceto nos últimos dias 
de negociações dos contratos. Contudo, a análise de Kenyon et al. (1991) não separa o efeito da liquidação financeira do efeito das demais alterações efetuadas no contrato simultaneamente.

Rich \& Leuthold (1993), incluindo um número maior de mercados na amostra, analisaram como a questão da liquidação financeira influenciou as condições de hedge para o contrato futuro de boi magro da CME, em mercados individuais e na atividade como um todo. $O$ estudo analisou o comportamento da base e o risco do hedging para 27 contratos futuros de boi magro nos períodos pré e pós introdução da liquidação financeira (abril de 1983 a agosto de 1986 e setembro de 1986 a novembro de 1989, respectivamente). Os meses de vencimento dos contratos foram janeiro, março, abril, maio, agosto, setembro, outubro e novembro.

Os dados disponíveis para a análise foram semanais e diários. Cada amostra semanal foi composta por 27 mercados à vista, localizados em 20 estados diferentes. As amostras para os dados diários referem-se a Oklahoma City e Dodge City, que representam os maiores mercados e, portanto, puderam ser considerados representativos para o estudo. Apenas a categoria de 600700 libras foi analisada, por apresentar menos falhas na série de preços. A base foi calculada como a diferença entre a média dos preços à vista e a média dos preços futuros na semana que incluía a data de vencimento do contrato.

Os autores testaram a hipótese nula de que as variâncias da base antes e depois da introdução da liquidação financeira seriam iguais, contra a hipótese alternativa de que a variância da base depois seria menor do que a variância da base antes. Foram testados 52 pares de variâncias através da estatística "F". Uma amostra dos dados da base na semana de vencimento do contrato contendo dez dos maiores mercados, foi testada para verificar a suposição da normalidade da distribuição dos dados e como ela se mostrou questionável, 
utilizou-se o teste Levene modificado e outros testes não-paramétricos, para testar a igualdade de variâncias. ${ }^{33}$

Os resultados indicaram que somente 13 dos 52 pares de variâncias testados pela estatística " $F$ ", apresentaram a variância da base significativamente menor, após a introdução da liquidação financeira. As mesmas variâncias submetidas aos testes de Levene modificado e nãoparamétricos revelaram que os resultados são sensíveis à suposição da normalidade, entretanto amplamente compativeis com a conclusão de que a liquidação financeira tem efeitos mistos na variabilidade da base em mercados individuais e efeitos favoráveis em termos gerais.

A média da base foi testada para verificar se seus níveis foram alterados depois da introdução da liquidação financeira. Foi utilizado o teste $t$ para testar a hipótese nula de que as médias da base antes e depois da introdução financeira seriam iguais, contra a hipótese alternativa de que as médias antes e depois seriam diferentes. Uma vez que os dados mostraram-se sensiveis à suposição da normalidade, foi utilizado o teste Mann-Whitney para verificar a mudança na localização central da base, uma vez que não há um teste específico para testar a igualdade de médias, quando a suposição da normalidade é questionável. Em $83 \%$ dos casos, a média da base aproximouse mais de zero após a introdução da liquidação financeira. A média da base próxima de zero implica que os preços à vista e futuro estão mais próximos do que anteriormente, no vencimento do contrato.

Ainda nesse sentido, um modelo de regressão foi utilizado para isolar o impacto da liquidação financeira sobre o risco de base e obter-se uma noção maior do risco do hedging quanto à localização e quanto ao sexo. 0 risco do hedging (caracterizado pelo risco de base) foi representado pelo desvio padrão da base na amostra (em US $\$ / 100$ libras). O modelo utilizado foi estimado pelo

\footnotetext{
${ }^{33}$ Estes testes são apropriados quando a suposição da normalidade é questionável (Rich \& Leuthold, 1993).
} 
método dos mínimos quadrados ordinários e os dados para as variáveis dependentes foram logaritmizados. Foram utilizadas variáveis binárias para representar sexo, liquidação financeira e localização. Os resultados encontrados sugeriram um decréscimo de $7,25 \%$ no risco do hedging, devido à introdução da liquidação financeira.

O modelo de regressão com dados semanais sugeriu que houve redução na variabilidade da base depois da mudança na forma de liquidação, pois o coeficiente encontrado para esta variável foi negativo. Em termos percentuais, entretanto, essa redução foi modesta. Os resultados para os mercados individuais foram ambiguos, mas as conclusões gerais não foram completamente negativas. Embora não estatisticamente ligado à introdução da liquidação financeira, foi encontrado que o risco de base na maturidade do contrato diminuiu sensivelmente na maioria dos mercados individuais.

Os resultados do estudo mostraram uma pequena melhoria na variabilidade da base depois da introdução da liquidação financeira para a maioria dos mercados individuais, juntamente com uma base distintamente menor e mais próxima de zero. Portanto, a adoção da liquidação financeira proporcionou melhorias na performance dos contratos para alguns hedgers, mas não para todos, pois os resultados diferiram entre as estações que informaram os preços. Os benefícios proporcionados foram no sentido da melhor convergência entre os preços à vista e futuro.

Os problemas existentes com o contrato futuro de boi magro, mesmo depois da introdução da liquidação financeira, tem levado a CME a promover mudanças periódicas nas especificações, de forma a torná-lo mais viável e útil para a realização do hedging. Assim, em, janeiro de 1993, algumas especificações desse contrato foram alteradas $e$ as duas principais modificações foram: o tamanho da unidade de negociação passou de 44.000 para 50.000 libras e um novo índice (CME Composite Weighted Average Price for Feeder Steers) foi adotado para liquidação financeira dos contratos. $O$ 
aumento da unidade de negociação visava à melhor adequação ao tamanho do veículo de transporte dos animais. A adoção de um novo índice para liquidação financeira pretendeu melhorar a representatividade dos preços do mercado à vista, pois a faixa de peso para o cálculo do indice foi reduzida para 700-799 libras $^{34}$ e a localização geográfica dos mercados passou a conter $70 \%$ de todo o gado comercializado. Além disso, o novo índice passou a ser calculado com base em dados publicados pelo United States Department of Agriculture (USDA), usando uma fórmula simples e disponível ao público, o que torna o índice mais confiável (CME, 1993).

O "CME Composite Weighted Average Price for Feeder Steers" começou a ser calculado em abril de 1991. Comparações entre este índice e o USFSP no período que abrange maio de 1991 a abril de 1992, feitas pela CME, indicaram uma redução no nível da base em Dodge City, após a adoção do novo índice. A variabilidade da base foi reduzida em 5 locais dentre os 12 incluídos no cálculo do novo índice e em 5 não incluídos neste cálculo (CME, 1993).

Neste contexto, é importante salientar que os estudos sobre o impacto da liquidação financeira e das mudanças nas especificações dos contratos sobre o risco de base tornam-se importantes instrumentos para orientar a CME na adoção de medidas visando melhorar os contratos futuros, a fim de incentivar seu uso pelos participantes do mercado.

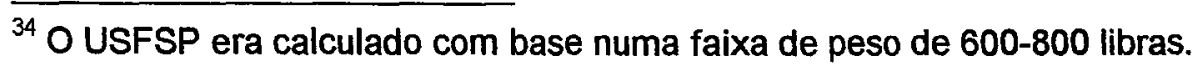




\section{MÉTODOS}

A seguir são descritos três métodos que foram adotados nos estudos que analisaram o risco de base no contrato futuro de boi magro da CME, citados na seção anterior. O primeiro, desenvolvido por Elam (1988) e utilizado também por Schroeder \& Mintert (1988), foi empregado para estudos com dados simulados para a liquidação financeira, pois a análise refere-se ao período de 1977 a 1986 e a liquidação financeira para os contratos futuros de boi magro da CME só foi adotada a partir de setembro de 1986. Esses autores calcularam a razão ótima e o risco do hedging para contratos com vencimento nos meses de janeiro, março, abril, maio, agosto, setembro, outubro $e$ novembro e consideraram categorias de animais não especificadas nos contratos futuros, quanto ao peso e ao sexo. Quando o hedging é feito para animais com características diferentes daquelas especificadas no contrato futuro, a operação é chamada de cross hedge e surge o risco adicional da diferença de preço entre o ativo hedgeado e aquele definido no contrato. Assim, os autores analisaram o risco de base para o hedging e para o cross hedging.

Para calcular a razão ótima de hedge, foi estimado um modelo, utilizando-se séries históricas dos preços à vista e futuro nos mercados considerados. Depois, o modelo foi estimado novamente, utilizando-se os mesmos preços à vista anteriormente considerados, mas empregou-se a série histórica do Cattle-Fax para representar os preços futuros sob liquidação financeira. Para representar os preços à vista e futuro foram utilizadas médias 
semanais dos preços à vista e futuro, respectivamente ${ }^{35}$. Desta forma, foi possivel comparar os resultados obtidos para a razão de hedge com entrega física e supondo liquidação financeira. Para medir o risco do hedging, foi utilizado o desvio padrão da diferença entre o preço líquido recebido com a operação de hedge e o preço esperado (hedgeado no início da operação).

$\mathrm{Na}$ verdade, o indice de preço à vista representa o valor atual da commodity, enquanto o preço futuro sob liquidação financeira representa uma estimativa do mercado do valor da commodity para uma data no futuro. Assim, os dois preços representam o valor da commodity em diferentes pontos no tempo. Conseqüentemente, na data do vencimento do contrato, o preço futuro será, na verdade, a cotação da commodity para aquele dia, ou seja, o preço à vista. Desta forma, o preço futuro igualaria o índice de preço à vista, para um contrato excelente (Kahl et al., 1989). Assim, embora o índice de preços à vista possa não representar os preços futuros sob liquidação financeira antes do vencimento do contrato, certamente ele refletirá esses preços na data do seu vencimento. Contudo, isso ocorrerá somente se as informações de preços representarem exatamente as condições de oferta e demanda no mercado à vista e forem adequadamente utilizadas para calcular 0 índice.

Elam (1988) e Schroeder \& Mintert (1988) tiveram de pressupor que os preços futuros sob liquidação financeira eram iguais à série histórica do USFSP, pois os preços futuros no período posterior à introdução da liquidação financeira não estavam disponíveis. Assim, os resultados estão baseados em preços futuros simulados sob liquidação financeira e só permanecem válidos se a relação entre o USFSP e os preços futuros continuar a mesma depois da sua introdução.

\footnotetext{
${ }^{35}$ Elam (1988) calculou a base apenas na semana que incluía o $15^{\circ}$ dia do mês de vencimento e Schroeder e Mintert (1988) calcularam a base para a semana que incluía o $15^{\circ}$ dia do mês anterior ao mês de vencimento do contrato até a semana que incluía $015^{\circ}$ dia do mês de vencimento.
} 
O método de análise desenvolvido por Elam (1988) e utilizado também por Schroeder \& Mintert (1988) apresenta limitações quanto à sua utilização no presente estudo. Uma vez que se dispõe de dados para os períodos pré e pós introdução da liquidação financeira, pode-se dar preferência aos métodos propostos para trabalhar com dados não simulados.

Rich (1990), num estudo bastante abrangente, desenvolveu modelos para identificar e analisar o impacto da introdução da liquidação financeira sobre a variabilidade da base para o contrato futuro de boi magro da CME, em mercados selecionados nos Estados Unidos. Para isso, foram utilizados dados dos períodos anterior e posterior à introdução da liquidação financeira

No mês de vencimento do contrato, três formas de cálculo da base foram empregadas: mensal, semanal e diária. A base mensal foi calculada como a média dos preços à vista semanais durante o mês de vencimento do contrato menos a média dos preços futuros semanais no mesmo mês. A base semanal foi calculada como a média dos preços à vista na semana que incluiu a data de vencimento do contrato menos a média dos preços futuros nesta mesma semana. A base diária foi calculada como o preço à vista menos o preço futuro em cada dia do mês de vencimento do contrato, em três mercados selecionados. Contudo, como nenhum desses mercados é ativo todos os dias da semana, a base foi calculada somente nos dias em que os preços estavam disponiveis. A base foi calculada para animais machos e fêmeas e foram utilizados no estudo 21 contratos antes e 15 depois da introdução da liquidação financeira.

Para cada forma de cálculo da base foi estimada sua variância para o periodo anterior (com 21 contratos) e para o período posterior (com 15 contratos) à mudança na forma de liquidação. Obteve-se, então, um par de variâncias para machos e outro para fêmeas, para cada mercado considerado. O autor utilizou a estatística " $F$ " para testar a igualdade de variâncias nos períodos anterior e posterior à introdução da liquidação financeira e verificar se 
esta afetou a variância mensal, semanal e diária da base no mês de vencimento do contrato.

Algumas considerações devem ser feitas a respeito do método empregado pelo autor para o cálculo da variância da base. Inicialmente, a base é uma série de valores ordenados no tempo. Assim, conceitualmente, ela demonstra um componente previsível, representado pela convergência entre os preços à vista e futuro (e padrões sazonais, se existirem) e outro componente aleatório, que determina o risco de base (Garcia et al., 1984). Portanto, para que a variância da base represente o risco, ela deve ser calculada a partir do componente aleatório da base. Desta forma, é necessário isolar as duas porções que a compõem, a fim de analisar sua variância durante o mês de vencimento do contrato.

Contudo, para as bases mensais e diárias, o autor calcula a variância da base a partir da série original, sem isolar a parte que representa o risco. Assim, o risco de base calculado pelo autor inclui equivocadamente a variação previsível e aleatória da base ${ }^{36}$. Já no caso dos dados semanais, como a base foi considerada apenas na semana que incluía a data de vencimento do contrato, a convergência entre os preços à vista e futuro já ocorreu e, então, apenas a porção aleatória da base é considerada. ${ }^{37}$

$O$ efeito da liquidação financeira sobre o risco de base foi isolado através da estimação de modelos de regressão, nos quais a variabilidade da base mensal foi expressa em função de variáveis binárias para representar a introdução da liquidação financeira, localização, sexo e uma variável para

\footnotetext{
${ }^{36}$ Se os fatores que prejudicam a convergência dos preços à vista e futuro forem eliminados pela introdução da liquidação financeira, a variância da base pode aumentar, em função de uma maior aproximação desses preços. Isto não significa que o risco de base tenha aumentado, pois os movimentos no sentido da melhor convergência de preços representam a variação da parte previsivel da base, que não é considerada risco. Por outro lado, se os fatores relacionados à entrega física prejudicam a aproximação dos preços, a base pode variar menos, porque os preços à vista e futuro não convergem. Neste caso, pequenas variações na base não devem ser interpretadas como baixo risco, pois a convergência é esperada durante o mês de vencimento do contrato e caso ela não ocorra, o risco de base estará aumentando.

${ }^{37}$ Professor Raymond M. Leuthold (University of Illinois). Comunicação pessoal, 1997.
} 
distinguir mercados incluídos no cálculo do índice de liquidação financeira daqueles não incluídos.

Um modelo de regressão foi estimado para mercados específicos, a fim de verificar a variabilidade semanal da base no mês de vencimento do contrato. Para isso, foi calculada a base em cada semana do mês de vencimento e a variância semanal foi estimada a partir dos valores obtidos. ${ }^{38}$ Novamente, a forma de calcular a variância da base inclui o mecanismo de convergência dos preços à vista e futuro, ou seja, a porção previsivel. Uma vez que na última semana do mês de vencimento do contrato espera-se que os preços já tenham convergido e nas primeiras semanas este processo ainda está começando, esta forma de cálculo da variância capta os movimentos relativos à aproximação dos preços à vista e futuro, que não compõem o risco de base.

Além de utilizar os dados dos períodos anterior e posterior à introdução da liquidação financeira, Rich (1990) analisa, concomitantemente à análise da variância da base, a evolução do volume de contratos em aberto. Esta análise é importante, pois a maior utilização dos contratos sustenta o argumento da redução no risco de base, uma vez que, conforme este último diminui, a performance do hedging melhora e o contrato se torna mais útil para os agentes do mercado.

O terceiro método, descrito a seguir, é aquele proposto por Rich \& Leuthold (1993). Os autores utilizaram em seu estudo, preços à vista e futuro do período anterior e posterior à introdução da liquidação financeira, para

${ }^{38} \mathrm{Var}=\frac{\sum_{i-1}^{n}\left(x_{i}-\bar{x}\right)^{2}}{n}$

onde:

Var = variância semanal da base no mês de vencimento do contrato;

$x_{i}=$ base na i-ésima semana do mês de vencimento, calculada como a média semanal do preço à vista menos a média semanal do preço futuro na respectiva semana;

$\bar{x}=$ média mensal das bases semanais $\left(x_{i}\right)$ no mês de vencimento, calculada com 4 ou 5 semanas;

$n=$ número de semanas no mês de vencimento do contrato (4 ou 5). 
verificar não só o impacto desta sobre o risco de base, mas também das mudanças adotadas pela CME quanto às especificações do contrato futuro de boi magro. Além disso, foi possível verificar se a introdução da liquidação financeira trouxe melhorias na convergência entre os preços à vista e futuro.

Rich \& Leuthold (1993) definiram a base como a diferença entre o preço à vista e o preço futuro. A base foi calculada somente para as semanas que incluíam a data de vencimento do contrato e os preços à vista e futuro foram representados pelas respectivas médias semanais na referida semana, para cada contrato considerado. A base foi calculada tanto para animais machos, como para fêmeas e o risco de base nos dois períodos foi representado pela sua variância.

Para verificar se a liquidação financeira afetou a variância da base do contrato futuro de boi magro da $\mathrm{CME}$, foram realizados testes de hipóteses para a igualdade de variâncias. Foram testados 54 pares de variâncias (dois pares referentes a cada um dos 27 mercados; um para machos e outro para fêmeas), cada par contendo as variâncias da base na semana de vencimento dos contratos para os períodos pré e pós introdução da liquidação financeira.

Foi utilizada, inicialmente, a estatística " $F$ " para testar os pares de variâncias. Contudo, para que se possa empregar este teste, é necessário que os dados tenham distribuição normal. Baseados em estudos anteriores (Hsieh \& Miller ${ }^{39}, 1990$, p.7), os autores argumentaram que, quando o teste "F" é empregado para amostras com distribuição de "cauda grossa", a hipótese nula é rejeitada muito freqüentemente. Desta forma, uma sub-amostra contendo dez das séries da base, foi testada pela estatística de Shapiro-Wilk para normalidade. Em $70 \%$ dos casos, a suposição da normalidade foi rejeitada.

${ }^{39} \mathrm{HSIEH}, \mathrm{D}$; MILLER, M. Margin regulation and stock market volatility. Journal of Finance, v.45, p.3-29, 1990. 
Assim, foi empregada a estatística de Levene modificada ${ }^{40}$ e o teste de MannWhitney (não-paramétrico) para testar a igualdade de variâncias.

Os testes de hipóteses realizados para a variância da base englobam tanto os efeitos das modificações nas especificações dos contratos, como o da introdução da liquidação financeira. Para isolar este último efeito sobre o risco de base e também para verificar como difere não só para machos e fêmeas mas também entre as regiōes dos Estados Unidos, os autores estimaram uma regressão de mínimos quadrados ordinários.

O desvio padrão da base, na semana de vencimento dos contratos, foi expresso em função das seguintes variáveis binárias: uma variável para representar a introdução da liquidação financeira e que assume valor 0 para o periodo anterior e 1 para o período posterior; uma variável para verificar a influência do sexo do animal sobre o risco de base, assumindo valor 0 para fêmeas e 1 para machos; 26 variáveis para representar a localização dos 27 mercados utilizados no estudo, que assumem valor 1 para o mercado considerado e valor 0 para os demais.

A fim de verificar se e como a introdução da liquidação financeira afetou o nível médio da base, os autores testaram também a média da base na semana de vencimento do contrato, através do teste $t$. Contudo, uma vez que a suposição da normalidade mostrou-se questionável e não há um teste especifico para averiguar a igualdade entre duas médias nesta situação, Rich \& Leuthold (1993) utilizaram, adicionalmente, o teste Mann-Whitney (nãoparamétrico) para verificar se as amostras da base na semana que incluía a data de vencimento do contrato, antes e depois da introdução da liquidação financeira, provinham de populaçōes com a mesma distribuição. Desta forma, foi possível fazer inferências sobre a mudança na localização central da base na semana de vencimento do contrato.

\footnotetext{
${ }^{40}$ Para maiores detalhes da estatística de Levene modificada, ver Brown \& Forsythe (1974).
} 
Até aqui, foram apresentados os três métodos utilizados nos estudos sobre o impacto da introdução da liquidação financeira sobre o risco de base no contrato futuro de boi magro da $\mathrm{CME}$, bem como suas vantagens e limitações. Antes de iniciar a descrição dos dados e métodos utilizados no presente estudo para analisar o impacto da introdução da liquidação financeira sobre o risco de base do contrato futuro de boi gordo da BM\&F, faz-se necessário esclarecer que as análises realizadas neste estudo referem-se apenas à semana e ao mês de vencimento dos contratos, devido ao comportamento da base para commodities não-estocáveis. Para elucidar porque apenas esses períodos foram levados em conta, as considerações teóricas que seguem baseiam-se em Leuthold, Junkus \& Cordier (1989).

Para commodities estocáveis, os preços à vista e futuro são formalmente relacionados pelos custos de estocagem, no periodo que precede o mês de vencimento do contrato. Uma vez que esses custos são aproximadamente constantes dentro de uma temporada, os preços à vista e futuro movem-se conjuntamente. Neste caso, o limite máximo da base é o custo completo de carregamento, que é o custo físico marginal para manter uma unidade da commodity da data presente até a maturidade do contrato futuro, mais o frete, para locais fora dos pontos de entrega.

Para commodities não-estocáveis, as decisões de variar a produção são a principal influência na relação de preços para essas mercadorias. Os mercados futuros são principalmente uma antecipação dos preços, porque eles não se baseiam em proporções fixas de estoques, como no caso de grãos. $A$ oferta e demanda por animais vivos e como os traders esperam que essas funçōes variem ao longo do tempo é que guiam a base para animais vivos. Assim, o conjunto de preços à vista e futuro não é formalmente relacionado para o periodo que precede o vencimento do contrato, como no caso de grãos. Não existe um limite teórico para o máximo ou mínimo tamanho da base para commodities não-estocáveis. 
Contudo, embora a base para as mercadorias não-estocáveis reflita um conjunto de diferentes condições em comparação com as commodities estocáveis, o padrão de comportamento das primeiras, assemelha-se ao destas últimas de uma maneira importante. Os preços à vista e futuro, tanto para commodities estocáveis como para não-estocáveis, devem gradualmente convergir, conforme se aproxima o mês de vencimento do contrato. Durante o período de entrega, a base deve aproximar-se de zero, pois caso isso não ocorra, haverá possibilidade de arbitragem entre os mercados à vista e futuro, conforme descrito na seção 2.3 .

Desta forma, o que se pode afirmar sobre o padrão de comportamento da base para commodities não-estocáveis é que os preços à vista e futuro convergem no mês de vencimento do contrato. Entretanto, durante o período que o precede, os preços à vista e futuro não estão formalmente relacionados, o que limita a análise proposta no presente estudo à semana e ao mês de vencimento do contrato futuro.

A seguir, são descritos os dados e os dois métodos adotados no presente estudo para verificar o impacto da introdução da liquidação financeira sobre o risco de base no contrato futuro de boi gordo da BM\&F. O primeiro foi utilizado para analisar o impacto da introdução da liquidação financeira sobre o risco de base na semana que inclui a data de vencimento do contrato e verificar se esse risco difere entre regiões e entre sexos. O segundo foi adotado para proceder esta análise no mês de vencimento do contrato.

\section{Os dados}

Foram utilizados, neste estudo, os preços futuros do contrato futuro cambial de boi gordo da BM\&F. Foram utilizados os preços à vista do Centro de Estudos Avançados em Economia Aplicada/Fundação de Estudos Agrários 
"Luiz de Queiroz" (CEPEA/FEALQ), para bois e vacas, referentes às regiões de Araçatuba, Bauru/Marília, Barretos/São José do Rio Preto, Presidente Prudente ${ }^{41}$, Três Lagoas, Triângulo Mineiro, Campo Grande, Goiânia e Norte do Paraná. Entretanto, esses preços à vista por região só começaram a ser coletados em 1994, quando o CEPEA/FEALQ iniciou o cálculo do IBG. Uma vez que estes preços à vista só estão disponiveis a partir de 1994, considerou-se o período anterior à introdução da liquidação financeira de outubro de 1994 a julho de 1995 e posterior à introdução da liquidação financeira de agosto de 1995 a fevereiro de 1997.

Desta forma, apesar de os preços para os contratos futuros de boi gordo da BM\&F estarem disponíveis a partir de 1991, ano em que o contrato foi relançado pela Bolsa, dispõe-se dos preços à vista por região somente a partir de 1994. Assim, os contratos considerados no estudo para o periodo anterior à introdução da liquidação financeira somam quatro (outubro/94, dezembro/94, março/95 e maio/95) e para o período posterior somam doze (agosto/95, outubro/95, dezembro/95, fevereiro/96, abril/96, junho/96, agosto/96, setembro/96, outubro/96, novembro/96, dezembro/96 e fevereiro/97).

Os preços à vista do CEPEA/FEALQ estão cotados em valores nominais por arroba, para um prazo de pagamento que varia de 10 a 30 dias. Estes preços foram trazidos para valor presente pela taxa de desconto da Nota Promissória Rural (NPR). O prazo de pagamento médio considerado para todo o período foi 23 dias, sendo 20 dias o prazo mais freqüente para pagamento no mercado físico e três dias para a escala de abate. Posteriormente, os valores foram convertidos em dólares nominais pela taxa de câmbio das operações de venda, uma vez que os preços futuros estão cotados em pontos por arroba líquida, com duas casas decimais, sendo cada ponto equivalente à taxa de

\footnotetext{
${ }^{41}$ Os preços dessas quatro regiões do Estado de São Paulo são utilizados para o cálculo do Indicador de Preço Disponível do Boi Gordo (IBG). No levantamento de preços feito pelo CEPEA/FEALQ, considera-se Bauru/Marília como uma mesma região, bem como Barretos/São José do Rio Preto.
} 
câmbio média entre as operações de venda de dólares dos Estados Unidos. Desta forma, foi possivel obter todos os preços em dólares americanos pelo valor nominal.

\subsection{Método utilizado para analisar o impacto da introdução da liquidação financeira sobre o risco de base na semana que inclui a data de vencimento do contrato}

O método utilizado para analisar o impacto da introdução da liquidação financeira sobre o risco de base dos contratos futuros de boi gordo da BM\&F, na semana de vencimento, foi aquele proposto por Rich \& Leuthold (1993). Pequenas modificações fizeram-se necessárias, a fim de adaptá-lo aos dados disponiveis ao presente estudo.

O método proposto pelos referidos autores utiliza dados dos periodos pré e pós introdução da liquidação financeira e permite isolar os efeitos desta sobre o risco de base e verificar como ele difere para machos e fêmeas e também para as regiōes consideradas no estudo. Além disso, permite investigar como a introdução da liquidação financeira afetou o nível médio da base na semana de vencimento do contrato.

O risco de base representa o risco do hedging para animais que se ajustam às especificações do contrato. No caso das fêmeas, ou vacas gordas, o risco de base representa o risco do cross hedging, pois o contrato futuro de boi gordo da BM\&F é especificado apenas para machos. Assim, como são considerados preços à vista para machos e fêmeas, este estudo sobre o impacto da introdução da liquidação financeira sobre o risco de base analisa tanto o risco do hedging como o risco do cross hedging.

De acordo com as considerações teóricas, espera-se que o risco de base no contrato futuro de boi gordo da BM\&F tenha sido reduzido, após a 
introdução da liquidação financeira. Cohen \& Gorham ${ }^{42}$, citados por Schroeder \& Mintert (1988), por Rich (1990) e por Rich \& Leuthold (1993), argumentaram que, devido à eliminação da volatilidade dos custos para receber ou proceder à entrega física, os niveis da base seriam alterados. Porém, não estava claro se a mudança para liquidação financeira aumentava ou diminuía o nível médio da base. Desta forma, é importante verificar como a introdução da liquidação financeira afetou o nível médio da base na semana de vencimento do contrato e identificar se a mudança na forma de liquidação veio melhorar a convergência dos preços à vista e futuro, conforme esperado.

A base nesta seção foi calculada como o preço à vista em cada regiāo menos o preço futuro, somente na semana que incluiu a data de vencimento do contrato ${ }^{43}$, de acordo com a fórmula (9). O preço à vista foi representado pela média dos preços à vista na semana de vencimento do contrato e o preço futuro pela média dos preços futuros nessa mesma semana.

$$
B=C-F
$$

onde:

$B$ = base na semana de vencimento do contrato;

$C=$ preço à vista (média semanal dos preços à vista na semana de vencimento do contrato);

$F=$ preço futuro (média semanal dos preços futuros na semana de vencimento do contrato).

\footnotetext{
${ }^{42}$ Cohen \& Gorham, op. cit., p. 23.

${ }^{43}$ Como já explicado anteriormente, no método proposto por Rich e Leuthold (1993), a base foi calculada somente na semana que inclui a data de vencimento do contrato, porque nessa semana espera-se que os preços à vista e futuro já tenham convergido e as variações da base devam-se apenas ao componente aleatório que representa o risco. A semana que incluiu a data de vencimento do contrato será referida, a partir desta seção, como semana de vencimento do contrato.
} 
Calculou-se a base para machos e fêmeas, para as quatro regiōes do Estado de São Paulo que compõem o cálculo do Indicador de Preço Disponível do Boi Gordo ESALQ/BM\&F (IBG), que são Araçatuba, Bauru/Marília, Barretos/ São José do Rio Preto e Presidente Prudente e também para cinco regiões para as quais os preços à vista diários da arroba do boi gordo estão disponiveis, a saber: Três Lagoas, Triângulo Mineiro, Campo Grande, Goiânia e Norte do Paraná. Desta forma, foi possivel verificar o impacto da liquidação financeira nas regiões que compõem o cálculo do IBG e também naquelas que não entram neste cálculo. Assim, a base na semana de vencimento de cada contrato foi calculada para 9 regiōes diferentes, para machos e fêmeas.

Como existem 4 contratos para o período anterior à introdução da liquidação financeira, existem também quatro observações da base na semana de vencimento nesse período, para cada mercado e para cada sexo. Por outro lado, como há 12 contratos para o período posterior à introdução da liquidação financeira, há também doze observações da base na semana de vencimento, para cada região e para cada sexo.

Para verificar o impacto da introdução da liquidação financeira sobre o risco de base na semana de vencimento do contrato, este foi representado pela variância da base em cada regiāo, para bois e vacas. A variância para cada região e para cada sexo foi calculada com 4 observações da base antes e 12 observações da base depois da mudança na forma de liquidação. Portanto, obteve-se a variância para o período anterior e posterior, para cada região e para cada sexo. Para verificar se a variância da base foi afetada pela introdução da liquidação financeira, as seguintes hipóteses foram testadas:

$$
\begin{aligned}
& \text { Ho: } \sigma_{\text {antes }}^{2}=\sigma_{\text {depois }}^{2} \\
& \text { Ha: } \sigma_{\text {antes }}^{2} \neq \sigma_{\text {depois }}^{2}
\end{aligned}
$$


onde:

$\sigma_{\text {antes }}^{2}=$ variância da base na semana de vencimento, dos contratos referentes ao período anterior à introdução da liquidação financeira;

$\sigma_{\text {depois }}^{2}=$ variância da base na semana de vencimento, dos contratos referentes ao período posterior à introdução da liquidação financeira.

Essas hipóteses foram testadas para 18 pares de variâncias (dois pares referentes a cada mercado; um para machos e outro para fêmeas) através da estatística de Levene modificada. Utilizou-se esta estatística, porque as amostras da base na semana de vencimento dos contratos são pequenas e a suposição da normalidade da distribuição das observações é questionável.

O teste de Levene modificado utilizado neste estudo não é o mesmo utilizado por Rich \& Leuthold (1993). Estes autores consideraram para o cálculo dos resíduos no teste, a média das amostras, calculada com a exclusão de $5 \%$ dos maiores e $5 \%$ dos menores valores observados, conforme sugerido por Brown \& Forsythe (1974). Entretanto, como os dados disponiveis para o presente estudo são escassos e as amostras da base na semana de vencimento, para os períodos anterior e posterior à introdução da liquidação financeira, são pequenas e de tamanhos diferentes, Brown \& Forsythe (1974), Conover et al. (1981) e O'Brien \& Tobias ${ }^{44}$ recomendam a estatística de Levene modificada, que faz uso da mediana da amostra para o cálculo dos resíduos no teste.

A seguir, é descrita a estatística de Levene modificada, utilizada no presente estudo para testar a igualdade de variâncias dos períodos anterior e posterior à introdução da liquidação financeira. Supondo que existam G grupos de dados, indexados por i=1...G, $n_{i}$ é o número de observações no i-ésimo

\footnotetext{
${ }^{44}$ O'BRIEN, R.G.; TOBIAS, R.D. Improvements and generalizations in modeling heterogenity of variance effects. Cary: Sas Institute, 1997. http://www.sas.com/rnd/app/stat/stanton.html
} 
grupo e $\sigma_{i}^{2}$ é a variância do i-ésimo grupo. Para testar a hipótese nula de que $\sigma_{1}^{2}=\sigma_{2}^{2}=\ldots \sigma_{G}^{2}$, sendo $x_{i j}$ a jota-ésima observação do i-ésimo grupo, a estatística de Levene modificada é calculada como segue.

$$
W=\frac{\left[\frac{\sum_{i} n_{i}\left(z_{i .}-z_{.}\right)^{2}}{(G-1)}\right]}{\left[\frac{\sum_{i} \sum_{j}\left(z_{i j}-z_{i .}\right)^{2}}{\sum_{i}\left(n_{i}-1\right)}\right]}
$$

onde:

$$
\begin{gathered}
z_{i .}=\frac{\sum_{j} x_{i j}}{n_{i}} \\
z_{. .}=\sum_{i} \sum_{j} \frac{z_{i j}}{\sum G} \\
z_{i j}=\mid x_{i j}-\text { Med }_{i} \mid
\end{gathered}
$$

e $\mathrm{Med}_{i}$ na equação (14) é a mediana do grupo $i$.

Sob a hipótese de que os $x_{i j}$ são independentes e identicamente distribuídos, $W$ é assintoticamente uma distribuição $F$, com $\left(G-1, \sum\left(n_{i}-1\right)\right)$ graus de liberdade.

Juntamente com a introdução da liquidação financeira, o contrato futuro de boi gordo da BM\&F sofreu as seguintes alterações:

1) cada ponto era equivalente à taxa de câmbio média entre as operações de compra e venda de dólares dos Estados Unidos e passou-se a considerar cada 
ponto equivalente à taxa de câmbio média entre as operações de venda de dólar dos Estados Unidos;

2) alteração nos meses de vencimento dos contratos futuros;

3) a data do vencimento do contrato e último dia de negociações que anteriormente era o décimo quinto dia útil do mês de vencimento do contrato passou a ser o último dia útil do mês de vencimento.

O teste de hipóteses para a igualdade de variâncias antes e depois da introdução da liquidação financeira capta o efeito desta e das outras modificações introduzidas no contrato simultaneamente. Para isolar apenas o impacto da mudança na forma de liquidação sobre o risco de base e verificar como este difere para cada região e para cada sexo, foi estimado um modelo de regressão. O risco de base foi representado pelo seu desvio padrão, calculado a partir das variâncias utilizadas nos testes descritos acima. ${ }^{45}$ Assim, uma vez que há 18 pares de variâncias (um par para machos e outro para fêmeas, para cada região) e cada par refere-se à variância dos períodos anterior e posterior à introdução da liquidação financeira, o modelo de regressão foi estimado a partir de 36 observações do desvio padrão da base na semana de vencimento. Para esclarecer melhor como as observações foram utilizadas na regressão, ver esquema no Apêndice 5.

O modelo de regressão foi estimado utilizando-se o método dos mínimos quadrados ordinários, no qual o desvio padrão da base na semana de vencimento do contrato foi expresso em função de variáveis binárias para isolar o efeito da liquidação financeira sobre o risco de base e também verificar como este difere para animais machos e fêmeas e para as diferentes regiões consideradas. O modelo utilizado é descrito a seguir:

\footnotetext{
${ }^{45}$ Foi utilizado o desvio padrão em vez da variância porque a variância oferece o inconveniente das unidades de medida ficarem elevadas ao quadrado.
} 


$$
\ln \left(s_{\text {base }_{h i j}}\right)=\beta_{1} L F_{h}+\beta_{2} \operatorname{Sexo}_{i}+\sum_{j=1}^{9} \delta_{j} L_{j}+u_{h i j}
$$

onde:

$\ln \left(s_{\text {base }}{ }_{h_{i j}}\right)=$ logaritmo neperiano do desvio padrão da base na semana de vencimento do contrato; o índice $h$ identifica se o desvio padrão refere-se ao período anterior ou posterior à introdução da liquidação financeira, $o$ índice $i$ identifica o desvio padrão para machos e fêmeas e $o$ índice $j$ identifica a região; $L F_{h}=$ variável binária para representar a introdução da liquidação financeira, que assume valor 0 , quando $h$ refere-se ao desvio padrão da base do período anterior e valor 1 , quando $h$ refere-se ao desvio padrão da base do período posterior a ela;

Sexo $_{i}=$ variável binária para representar o sexo do animal, que assume valor 0 , quando $i$ refere-se ao desvio padrão da base para fêmeas e valor 1 , quando $i$ refere-se ao desvio padrão da base para machos;

$L_{j}=$ variável binária para localização, que assume valor 1 para a região $j$, à qual refere-se o desvio padrão da base e valor 0 para as demais regiões. 0 indice $j$, que indica a região, varia de 1 a 9 e tem-se $L_{1}=$ Araçatuba, $L_{2}=$ Bauru/Marília, $L_{3}=$ Barretos/São José do Rio Preto, $L_{4}=$ Presidente Prudente, $L_{5}=$ Três Lagoas, $L_{6}=$ Triângulo Mineiro, $L_{7}=$ Campo Grande,$L_{8}=$ Goiânia e $L_{9}=$ Norte do Paraná;

$u_{h_{i j}}=$ erro de estimação do modelo.

O desvio padrão da base foi logaritmizado para estabilizar a sua variância e permitir a estimação dos parâmetros pelo método de mínimos quadrados ordinários. 
Além de determinar se a liquidação financeira afetou a variância da base, é importante verificar também se promoveu uma melhor convergência entre os preços à vista e futuro na semana de vencimento do contrato, pela eliminação dos problemas relacionados à entrega física. Para isso, é necessário identificar se houve alteração no nível médio da base na semana de vencimento do contrato, após a introdução da liquidação financeira. 0 procedimento para obter esse resultado consiste no teste de hipóteses sobre a igualdade das médias entre duas amostras da base, uma do período anterior e outra do período posterior à introdução da liquidação financeira. O teste indicado para tal é o teste $t$, que depende, porém, da suposição de que as amostras têm distribuição normal.

Como já colocado anteriormente, existem poucos dados disponíveis para este estudo e as amostras da base na semana de vencimento, referentes aos períodos anterior e posterior à introdução da liquidação financeira, são pequenas. Portanto, testar a normalidade da distribuição dos dados com um tamanho de amostra tão reduzido. não é adequado, como também não o é, supor que essa distribuição se aproxima da normal. Assim, pode-se considerar que a suposição da normalidade das amostras é questionável.

Diferentemente dos testes para igualdade de variâncias, nesta situação não há um teste especifico para a igualdade das médias de duas amostras, quando a suposição da normalidade é questionável. Testes não-paramétricos poderiam ser utilizados, como fizeram Rich \& Leuthold (1993), porém, são menos poderosos do que o teste $t$ (paramétrico) e testam a localização do valor central das distribuições, não especificamente sua média.

Assim, optou-se por adotar o teste $t$ para verificar a igualdade da base média na semana de vencimento do contrato, para os períodos anterior e posterior à introdução da liquidação financeira. Entretanto, é necessário fazer a ressalva de que o teste $t$ foi utilizado, apesar de a suposição de distribuição 
normal para as amostras da base na semana de vencimento do contrato ser questionável.

A base média para os períodos anterior e posterior à introdução da liquidação financeira foi calculada como a média aritmética das observações da base na semana de vencimento dos contratos referentes aos respectivos períodos. Para o período anterior, em cada mercado e para cada sexo, quatro observações (referentes a 4 contratos) foram utilizadas no cálculo da base média. Para o período posterior, doze observações (referentes a 12 contratos) foram utilizadas para calcular a base média, para cada mercado e para cada sexo.

A fim de identificar se houve mudança no nivel médio da base na semana de vencimento do contrato futuro, após a introdução da liquidação financeira, foram testados 18 pares de bases médias (dois pares para cada mercado; um referente a machos e outro referente a fêmeas). Utilizando-se o teste $t^{46}$, as seguintes hipóteses foram testadas:

$$
\begin{aligned}
& \text { Ho: } \bar{B}_{\text {antes }}=\bar{B}_{\text {depois }} \\
& \mathrm{Ha}: \bar{B}_{\text {antes }} \neq \bar{B}_{\text {depois }}
\end{aligned}
$$

onde:

$\bar{B}_{\text {antes }}=$ média das bases nas semanas de vencimento, dos contratos referentes ao periodo anterior à introdução da liquidação financeira;

$\bar{B}_{\text {depois }}=$ média das bases nas semanas de vencimento, dos contratos referentes ao período posterior à introdução da liquidação financeira.

\footnotetext{
${ }^{46}$ Para calcular o valor de $t$, é necessário fazer suposições a respeito da variância das amostras; se são supostas iguais ou diferentes. A suposiçäo foi feita, em cada caso, de acordo com os resultados obtidos nos testes para igualdade de variâncias das respectivas amostras, descritos na seção 5.1 .
} 


\subsection{Método utilizado para analisar o impacto da introdução da liquidação financeira sobre o risco de base no mês de vencimento do contrato}

Para verificar como a introdução da liquidação financeira afetou o risco de base no mês de vencimento dos contratos, em cada mercado e para cada sexo individualmente, e também para identificar se este difere em função do vencimento ocorrer nos meses de safra e entressafra da oferta de gado bovino para abate, foi adotado um método de análise diferente.

Durante o mês de vencimento do contrato, os preços à vista e futuro tendem a convergir para um mesmo valor. Considerando que na semana de vencimento do contrato esta convergência já ocorreu, toda variação da base deve-se a movimentos aleatórios, que representam o risco. Porém, durante o mês de vencimento do contrato, a convergência dos preços ainda está ocorrendo, o que torna necessária a utilização de um método diferente daquele adotado para analisar o risco de base na semana de vencimento. $O$ método utilizado para analisar o risco de base no mês de vencimento do contrato é descrito a seguir.

Nesta seção, a base foi calculada como o preço à vista menos o preço futuro, a cada dia do mês de vencimento do contrato, para machos e fêmeas em cada uma das nove regiões consideradas no estudo. Todavia, como a base durante o mês de vencimento do contrato futuro é uma série de observações ordenadas no tempo, esta pode ser descrita pela equação (17):

$$
B_{t}=S_{t}+e_{t}
$$

onde:

$B=$ base;

$S=$ componente previsivel;

e = componente aleatório; 
$t=$ periodo de observação (neste caso, $t$ representa cada dia do mês de vencimento do contrato).

Assim, a base é composta por uma porção previsível, representada no presente estudo pelo mecanismo de convergência entre os preços à vista e futuro $^{47}$ e por uma porção aleatória, que se refere aos movimentos imprevisiveis, ou risco de base. Presume-se que o componente previsivel de variação da base pode ser identificado e utilizado por produtores e participantes do mercado, em suas estratégias. Conseqüentemente, o risco de base aumenta, conforme aumenta a variância do componente aleatório. (Garcia et al., 1984). Desta forma, é necessário isolar este componente da base no mês de vencimento do contrato, a fim de que apenas a porção que representa o risco seja analisada.

Garcia et al. (1984) isolaram a parte aleatória da base, a fim de medir e analisar seu risco para mercados selecionados de bovinos e suínos nos Estados Unidos. Os autores utilizaram o enfoque das diferenças, que supõe que o valor esperado da série, ou seja, a porção previsivel, pode ser aproximada por polinômios da variável no tempo. A diferença destes polinômios elimina a expectativa da série temporal e deixa apenas o elemento aleatório, isto é, os desvios em relação ao valor esperado.

Baseado em Garcia et al. (1984), procurou-se isolar o componente aleatório da base, a fim de analisar seu risco no mês de vencimento dos contratos futuros. Para isso, foram feitas defasagens sucessivas em relação à série original da base, até que esta se tornasse estacionária e o resíduo resultasse numa série ruído branco. Foram utilizados os testes AIC (AKAIKE Information Criterion) e SC (SCHUARTZ Information Criterion), para determinar

\footnotetext{
${ }^{47}$ Se existir um padrão sazonal dos preços à vista, este pode estar refletido nos padrões sazonais de flutuação da base.
} 
a ordem de integração do processo autoregressivo da base. Esses testes são representados, respectivamente, pelas seguintes equações:

$$
\begin{aligned}
& A I C=\ln \hat{\sigma}^{2}+\left(\frac{2}{T}\right)\left(n^{\circ} \text { de parâmetros }\right) \\
& S C=\ln \hat{\sigma}^{2}+\left(\frac{\ln T}{T}\right)\left(n^{\circ} \text { de parâmetros }\right)
\end{aligned}
$$

onde $\sigma^{2}$ é a soma de quadrados de resíduos da equação auto-regressiva, nas defasagens sucessivas, em relação à série original, representada pela equação (20) e $T$ é o número de observações utilizado para estimá-la. A ordem do processo auto-regressivo é a que resultar no menor valor desses critérios, considerando-se uma seqüência de ajustamentos, na qual o número de defasagens do modelo aumenta sucessivamente, a partir da equação (20) (Bacchi, 1997) ${ }^{48}$.

$$
B_{t k}=\alpha+\beta_{1} B_{k t-1}+e_{t}
$$

onde $k$ identifica o mês de vencimento do contrato futuro ao qual se refere a série da base.

Os testes de AIC e SC para determinar as ordens de defasagens foram feitos para as séries da base nos meses de vencimento dos contratos, que são 4 antes e 12 depois da introdução da liquidação financeira. Assim, como para cada região existem 16 meses de vencimento e considerando que a base foi calculada para machos e fêmeas, foram testadas 32 séries de bases para cada uma das nove regiões.

\footnotetext{
${ }^{48}$ BACCHI, M.R.P. Uma avaliação da eficiência na formação de preços do açúcar cristal cambial da BM\&F. 1997, (Mimeografado).
} 
Depois de determinadas as ordens de defasagem de cada série da base, foi estimada uma regressão para cada mês de vencimento. $A$ base foi calculada para machos e fêmeas e a cada mês de vencimento corresponde uma série da base. Uma vez que existem 16 contratos, foram estimadas 32 regressões por região, a fim de isolar o componente aleatório da base e determinar seu desvio padrão.

Depois que o desvio padrão do componente aleatório da base foi determinado para cada mês de vencimento, para cada região e para cada sexo, foi possivel estimar regressões, a fim de verificar se e como a introdução da liquidação financeira afetou o risco de base no mês de vencimento do contrato. Adicionalmente, foi possível identificar se o risco de base difere para contratos com mês de vencimento no período de safra e entressafra da oferta de gado bovino para abate.

Foi estimada uma regressão para cada região e para cada sexo separadamente (18 ao todo), através do método dos mínimos quadrados ordinários. Cada regressão foi estimada com um total de 16 observações, ou seja, como existem 16 contratos, cada observação corresponde ao desvio padrão do componente aleatório da base em um mês de vencimento. $O$ modelo utilizado para estimar as regressões foi:

$$
\ln \left(\sigma_{\text {bass } i j_{j}}\right)=\beta_{1} S A Z_{i}+\beta_{2} L F_{j}+u_{i j}
$$

onde:

$\ln \left(\sigma_{\text {base } i j_{j}}\right)=$ logaritmo neperiano do desvio padrão do componente aleatório da base; $o$ índice $i$ refere-se ao mês de vencimento do contrato e o índice $j$ referese ao período ao qual pertence o contrato (anterior ou posterior à introdução da liquidação financeira); 
$S A Z_{i}=$ variável binária para representar a sazonalidade, que assume valor 0 quando $i$ refere-se aos contratos com vencimento na entressafra e 1 para aqueles que vencem na safra. Considerou-se o primeiro semestre do ano como período de safra e o segundo como período de entressafra da oferta de gado bovino para abate;

$L F_{j}=$ variável binária para representar a introdução da liquidação financeira, que assume valor 0 quando $j$ refere-se ao período anterior e valor 1 para 0 período posterior.

$u_{i j}=$ erro de estimação do modelo. 


\section{RESULTADOS E DISCUSSÃO}

6.1. Resultados do estudo do impacto da introdução da liquidação financeira sobre o risco de base na semana de vencimento do contrato

6.1.1. Resultados dos testes de igualdade de variâncias da base na semana de vencimento do contrato

Foram testados 18 pares de variâncias da base na semana de vencimento do contrato, conforme descrito nas hipóteses (10) na seção 5.1 , através da estatística de Levene modificada, para verificar o impacto da introdução da liquidação financeira sobre o risco de base. A tabela 1 mostra os pares de variâncias testados pela referida estatística e os resultados obtidos nos testes, para machos e fêmeas, nas regiões consideradas no estudo. 
Tabela 1. Variância da base na semana de vencimento do contrato, para machos e fêmeas, nos períodos anterior e posterior à introdução da liquidação financeira e resultados dos testes de Levene modificado para machos e fêmeas em cada região.

Machos

Fêmeas

\begin{tabular}{lcccccc}
\hline Regiões & $\mathbf{s}^{2}$ antes & $\mathbf{s}^{2}$ depois & Valores de $\mathbf{F}$ & $\mathbf{s}^{2}$ antes & $\mathbf{s}^{2}$ depois & Valores de $\mathbf{F}$ \\
\hline Araçatuba & 3,3392 & 0,1078 & $11,8983^{*}$ & 6,1832 & 0,5266 & $19,5220^{*}$ \\
Bauru/Marilia & 3,4443 & 0,1136 & $15,3767^{*}$ & 7,3362 & 0,3188 & 23,5388 * \\
Barretos/SJRP & 4,1898 & 0,1097 & $9,2140^{*}$ & 6,0368 & 0,4703 & $7,0729^{* *}$ \\
Presidente Prudente & 4,1222 & 0,1425 & $20,6493^{*}$ & 8,3625 & 0,4544 & $17,7439^{*}$ \\
Três Lagoas & 4,6912 & 0,1936 & $29,8167^{*}$ & 7,5706 & 0,7270 & $17,3880^{*}$ \\
Triângulo Mineiro & 3,5405 & 0,2698 & $7,2595^{* *}$ & 6,6885 & 0,6032 & 8,7214 * \\
Campo Grande & 8,0648 & 0,3449 & $30,1172 *$ & 10,5909 & 0,6319 & $28,2197^{*}$ \\
Goiânia & 3,6431 & 0,2981 & $19,4816^{*}$ & 8,5635 & 0,4835 & $25,9485^{*}$ \\
Norte do Paraná & 4,1401 & 0,3438 & $19,8484^{*}$ & 5,4133 & 0,5487 & 9,7902 * \\
\hline
\end{tabular}

* valor de $\mathrm{F}$ significativo a $1 \%$.

** valor de F significativo a $2 \%$.

Observando-se as variâncias da base antes e depois da mudança na forma de liquidação, nota-se uma grande redução na magnitude dos valores, do primeiro para o segundo período. Através dos resultados dos testes de Levene modificado, observa-se que a hipótese nula foi rejeitada em todos os casos, indicando que a introdução da liquidação financeira reduziu o risco de base para machos e fêmeas, para todas as regiōes consideradas no estudo. Todos os testes foram altamente significativos, embora o tamanho das amostras seja pequeno e diferente para os dois períodos. Os resultados indicam que o risco do hedging e o risco do cross hedging foram reduzidos,

${ }^{49}$ A sigla SJRP refere-se à região de São José do Rio Preto. 
tanto para as regiões que compõem o cálculo do IBG, como para aquelas que não integram esse cálculo.

De acordo com as considerações teóricas, dois motivos podem ter levado à redução do risco de base dos contratos futuros de boi gordo da BM\&F. O primeiro é a eliminação dos custos e problemas relacionados à entrega física. Esses fatores prejudicavam os movimentos de convergência de preços e, portanto, levavam a uma maior variação do componente aleatório da base. Com a eliminação dos problemas referentes à entrega física, houve uma redução na variação desse componente, ou seja, uma redução no risco de base.

O segundo motivo que pode explicar a redução do risco de base é a utilização de um índice que representa uma média dos preços no mercado à vista para liquidar os contratos e não mais a entrega física da mercadoria no vencimento. Em tal contexto, os agentes com posições comprada ou vendida em futuros não temem arcar com os custos e responsabilidades para entregar ou receber a mercadoria nessa data. Assim, não estão mais sujeitos a pagar um valor acima ou abaixo do preço à vista nos pontos de entrega para inverter suas posições e sair do mercado futuro e as flutuaçōes do preço futuro, que ocorriam independentemente do preço à vista (squeezes), durante o período de entrega, deixam de existir. Conseqüentemente, espera-se que o risco de base tenha sido reduzido.

Uma vez que, após a introdução da liquidação financeira, o risco de base foi reduzido para todas as regiões consideradas e também para machos e fêmeas, pode-se concluir que o IBG, utilizado para liquidar os contratos financeiramente, está refletindo adequadamente o preço do boi gordo no mercado à vista.

Segundo Rich (1990), se a liquidação financeira elimina os custos e problemas relacionados à entrega física e reduz o risco de base, então os contratos futuros tendem a ser mais utilizados pelos agentes do mercado. A fim 
de verificar esse argumento, torna-se importante analisar a evolução do volume de contratos negociados nos períodos anterior e posterior à introdução da liquidação financeira. A figura 3 mostra o número de contratos futuros de boi gordo negociados mensalmente na BM\&F, a partir de junho de 1991 até fevereiro de 1997.

Figura 3. Evolução do número de contratos futuros de boi gordo negociados mensalmente no período de junho de 1991 a fevereiro de 1997.

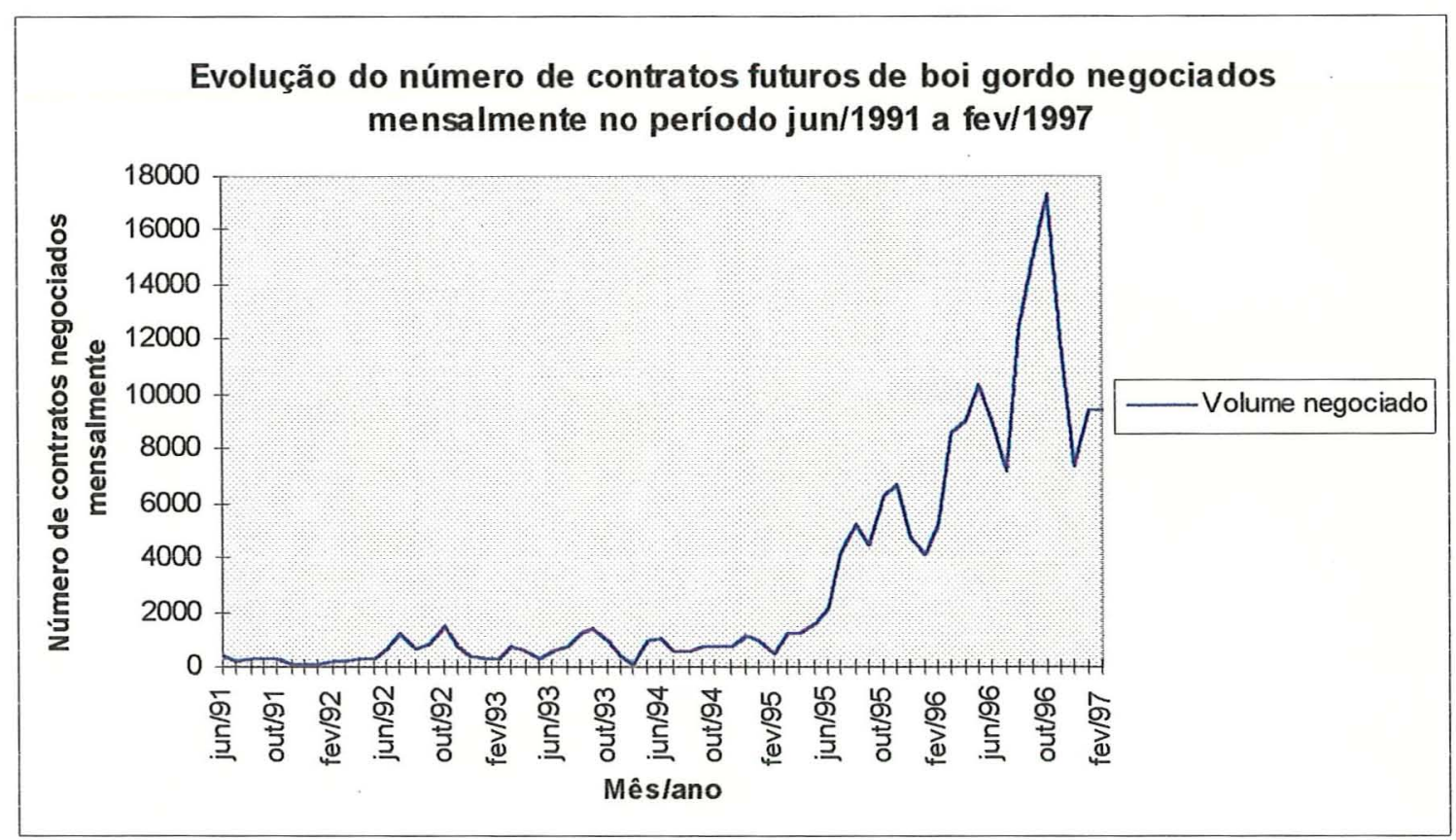

Fonte: BM\&F.

Pode-se notar que houve um aumento significativo no volume de contratos negociados, após a mudança na forma de liquidação, introduzida em dezembro de 1994, para o contrato com vencimento em agosto de 1995. O volume de contratos negociados no período de junho de 1991 a dezembro de 1994, antes da mudança na forma de liquidação, foi 21.732. Em 1995, 
negociaram-se 37.182 contratos $^{50}$, ou seja, em apenas um ano sob liquidação financeira dos contratos, o volume negociado superou o total transacionado em quatro anos, quando a entrega física era obrigatória. Durante o ano de 1996, o número de contratos negociados saltou para 117.395 e o acumulado de janeiro e fevereiro de 1997, já somou 18.786 contratos negociados.

Este crescimento expressivo e sucessivo no número de contratos negociados, após a introdução da liquidação financeira, indica que ela está fortemente associada ao aumento da liquidez no mercado futuro de boi gordo, via redução do risco de base ${ }^{51} e$ liberação da entrega física no vencimento do contrato. Por outro lado, o significativo aumento do volume de contratos negociados propicia condições para redução no risco de base, pois de acordo com Rich (1990), espera-se que quanto maior a liquidez do mercado futuro, menor a volatilidade dos preços futuros e, conseqüentemente, menor o risco de base.

\subsubsection{Resultados do modelo de regressão do desvio padrão da base na semana de vencimento do contrato}

Identificado o impacto da introdução da liquidação financeira sobre a variância da base, ele foi isolado das outras modificações introduzidas ao mesmo tempo no contrato, a fim de determinar a magnitude da redução no risco de base e verificar se este difere entre regiões e entre sexos.

\footnotetext{
${ }^{50}$ Estão excluídos deste volume, as negociações para os contratos com vencimento em março e maio de 1995, pois para esses contratos a liquidação no vencimento ainda deveria ser obrigatoriamente por entrega física.

51 É importante acrescentar, entretanto, que a BM\&F tem realizado diversos programas de incentivo ao desenvolvimento do mercado futuro de agropecuários, intensificados a partir de 1993. Assim, estes podem ter levado, juntamente com a adoção da liquidação financeira, ao aumento da liquidez do mercado futuro de boi gordo.
} 
O modelo estimado, de acordo com a equação (15), discutida na seção 5.1 , resultou num valor $F=91,560$, indicando que a regressão foi significativa a $1 \%$. O coeficiente de regressão ajustado para graus de liberdade $\left(\bar{R}^{2}\right)$ apresentou um valor bastante elevado $(0,9651)$, indicando que o modelo utilizado explica uma proporção elevada da variação no desvio padrão da base nos períodos anterior e posterior à introdução da liquidação financeira. Os resultados das estimativas dos parâmetros da regressão são apresentados na tabela 2.

Tabela 2. Resultados da regressão do logaritmo do desvio padrão da base na semana de vencimento do contrato em função de variáveis binárias para liquidação financeira, sexo e localização.

\begin{tabular}{lcc}
\hline \multicolumn{1}{c}{ Variáveis } & Estimativas dos parâmetros & Valores de t \\
\hline LF & $-1,4306$ & $-29,809^{*}$ \\
L1 (Araçatuba) & 0,9303 & $11,689^{*}$ \\
L2 (Bauru/Marilia) & 0,8967 & $11,267^{*}$ \\
L3 (Barretos/SJRP) & 0,9415 & $11,830^{*}$ \\
L4 (Presidente Prudente) & 1,0073 & $12,656^{*}$ \\
L5 (Três Lagoas) & 1,1077 & $13,918^{*}$ \\
L6 (Triângulo Mineiro) & 1,0771 & $13,533^{*}$ \\
L7 (Campo Grande) & 1,2717 & $15,979^{*}$ \\
L8 (Goiânia) & 1,0989 & $13,807^{*}$ \\
L9 (Norte do Paraná) & 1,0883 & 13,674 * \\
Sexo & $-0,3833$ & $-7,986$ * \\
\hline
\end{tabular}

* valor de $t$ significativo a $1 \%$.

De acordo com os resultados obtidos nos testes de variância, o sinal do coeficiente para liquidação financeira foi negativo, confirmando que sua introdução reduziu o risco de base. Uma vez que se utilizou o logaritmo do 
desvio padrão da base, é necessária a transformação do coeficiente das variáveis binárias, de acordo com a equação (22), para obter seu efeito relativo sobre a variável dependente (Halvorsen \& Palmquist, 1980).

$$
\exp (\text { coeficiente da variável binária) - } 1
$$

Assim, utilizando a equação (22) para verificar o efeito da introdução da liquidação financeira sobre o desvio padrão da base, obtém-se o valor -0,7608. Este valor indica que a mudança na forma de liquidação levou a uma redução de $76,08 \%$ no desvio padrão da base. Uma vez que a variável binária para representar esse efeito foi altamente significativa, pode-se concluir que, após a introdução da liquidação financeira, o risco de base foi reduzido em $76,08 \%$, na semana de vencimento do contrato.

A variável binária Sexo foi incluída no modelo para identificar se o risco de base difere para machos e fêmeas. $O$ coeficiente desta variável foi negativo e altamente significativo, indicando que o desvio padrão da base é menor para bois do que para vacas, uma vez que a variável binária assumiu valor um para machos e zero para fêmeas. Esse resultado se apresenta de acordo com o esperado, uma vez que o contrato futuro de boi gordo da BM\&F é especificado para animais machos. Desta forma, pode-se concluir que o risco de base é menor para as operações de hedge do que para as de cross hedge, pois estas últimas apresentam o risco adicional da diferença de preço entre o ativo hedgeado (animais fêmeas) e aquele especificado no contrato (animais machos).

As variáveis binárias para localização, introduzidas para verificar se o risco de base difere entre as regiões consideradas, apresentaram-se todas com sinal positivo e estatisticamente significativas. Observando-se os valores dos coeficientes, pode-se notar que o risco de base é menor para todas as regiões que compõem o cálculo do IBG, em relação às demais. 
Para verificar se o risco do hedging difere estatisticamente entre as regiões consideradas no estudo, foram realizados testes de hipóteses sobre a igualdade dos coeficientes das variáveis que representam localização. Em cada teste, a hipótese nula foi de que os coeficientes de duas variáveis para localização seriam iguais contra a hipótese alternativa de que estes seriam diferentes. Através da estatística " $F$ ", foram testados 36 pares de coeficientes, correspondentes a 36 combinações, dois a dois. Os resultados desses testes de hipóteses são apresentados na tabela 3.

Pode-se observar através dos coeficientes apresentados na tabela 2 e dos resultados dos testes mostrados na tabela 3, que na região de Araçatuba, o risco de base é estatisticamente menor do que nas regiões de Campo Grande e Três Lagoas. Já na região de Bauru/Marília, o risco de base é menor em relação a todas as regiões que não compõem o cálculo do IBG. Nas regiões de Barretos/São José do Rio Preto e Presidente Prudente, o risco de base é menor apenas em relação a Campo Grande.

Entre as regiões que compõem o cálculo do IBG, o risco de base não foi estatisticamente diferente. Esse resultado era esperado, uma vez que o Indicador é calculado a partir dos preços à vista dos principais centros de comercialização de boi gordo no Estado de São Paulo. Conseqüentemente, se ele tem refletido as condições de oferta e demanda desses mercados, esperase que o risco de base entre as regiões que o compõem não seja diferente. Conclui-se, desta forma, que o Indicador tem refletido adequadamente os preços desses mercados.

É interessante notar, ainda, que o risco de base na região de Campo Grande é estatisticamente maior do que o risco de base em todas as demais regiōes consideradas. Provavelmente, tal resultado esteja ligado a características próprias do mercado em questão. Os resultados obtidos por $\mathrm{De}$ Zen (1997) indicaram que dentre as regiões analisadas para verificar a integração entre os mercados de boi gordo e carne bovina no centro-sul do 
Brasil, Campo Grande foi o único mercado que não apresentou causalidade de preço com o mercado de carne na grande São Paulo.

Tabela 3. Resultados dos testes " $F$ " sobre a igualdade dos coeficientes das variáveis para localização.

\begin{tabular}{|c|c|}
\hline Hipóteses nulas & Valores de F \\
\hline Ho: Araçatuba = Bauru/Marilia & 0,1088 \\
\hline Ho: Araçatuba = Barretos/SJRP & 0,0122 \\
\hline Ho: Araçatuba $=$ Presidente Prudente & 0,5720 \\
\hline Ho: Araçatuba = Três Lagoas & $3,0363 * \star \star \star$ \\
\hline Ho: Araçatuba = Triângulo Mineiro & 2,0800 \\
\hline Ho: Araçatuba = Campo Grande & 11,2497 * \\
\hline Ho: Araçatuba = Goiânia & 2,7423 \\
\hline Ho: Araçatuba $=$ Norte do Paraná & 2,4081 \\
\hline Ho: Bauru/Marília = Barretos/SJRP & 0,1940 \\
\hline Ho: Bauru/Marilia = Presidente Prudente & 1,1798 \\
\hline Ho: Bauru/Marilia = Três Lagoas & $4,2947^{\star \star \star}$ \\
\hline Ho: Bauru/Marília = Triângulo Mineiro & $3,1402 * \star * *$ \\
\hline Ho: Bauru/Marilia = Campo Grande & 13,5712 * \\
\hline Ho: Bauru/Marília = Goiânia & 3,9436 **** \\
\hline Ho: Bauru/Marília = Norte do Paraná & $3,5406^{* \star \star \star}$ \\
\hline Ho: Barretos/SJRP = Presidente Prudente & 0,4169 \\
\hline Ho: Barretos/SJRP = Três Lagoas & 2,6630 \\
\hline Ho: Barretos/SJRP = Triângulo Mineiro & 1,7731 \\
\hline Ho: Barretos/SJRP = Campo Grande & 10,5199 * \\
\hline Ho: Barretos/SJRP = Goiânia & 2,3881 \\
\hline Ho: Barretos/SJRP = Norte do Paraná & 2,0770 \\
\hline Ho: Presidente Prudente $=$ Três Lagoas & 0,9725 \\
\hline Ho: Presidente Prudente = Triângulo Mineiro & 0,4704 \\
\hline Ho: Presidente Prudente $=$ Campo Grande & $6,7481 * \star \star$ \\
\hline Ho: Presidente Prudente = Goiânia & 0,8094 \\
\hline Ho: Presidente Prudente = Norte do Paraná & 0,6328 \\
\hline Ho: Três Lagoas = Triângulo Mineiro & 0,0902 \\
\hline Ho: Três Lagoas $=$ Campo Grande & 2,5971 \\
\hline Ho: Três Lagoas = Goiânia & 0,0075 \\
\hline Ho: Três Lagoas $=$ Norte do Paraná & 0,0364 \\
\hline Ho: Triângulo Mineiro = Campo Grande & 3,6551 **** \\
\hline Ho: Triângulo Mineiro = Goiânia & 0,0457 \\
\hline Ho: Triângulo Mineiro = Norte do Paraná & 0,0120 \\
\hline Ho: Campo Grande = Goiânia & $2,8835^{\star \star \star \star \star}$ \\
\hline Ho: Campo Grande = Norte do Paraná & $3,2481 * * * *$ \\
\hline Ho: Goiânia = Norte do Paraná & 0,0109 \\
\hline
\end{tabular}


6.2. Resultados do estudo do impacto da introdução da liquidação financeira sobre o risco de base no mês de vencimento do contrato

As ordens de integração das séries da base, determinadas através dos testes de AIC e SC, bem como os desvios padrões das auto-regressões, utilizados para representar a variação do componente aleatório da base durante o mês de vencimento dos contratos, são apresentados no Apêndice 6.

Conforme descrito na seção 5.2, a equação (21) foi utilizada para estimar regressões do desvio padrão do componente aleatório da base no mês de vencimento do contrato, em função de variáveis binárias. Para verificar o impacto da introdução da liquidação financeira, a variável binária assumiu valor zero para o período anterior e um para o período posterior a ela e, para identificar sazonalidade no risco de base, a variável binária assumiu valor um para os contratos com meses de vencimento na safra e valor zero para aqueles que vencem nos meses da entressafra da oferta de gado bovino para abate. Foi estimada uma regressão para cada região e para cada sexo. Os resultados para machos são apresentados nas tabelas 4 e 5 e os resultados para fêmeas nas tabelas 6 e 7 . 
Tabela 4. Resultados das regressões do desvio padrão da base para machos no mês de vencimento do contrato em função da liquidação financeira e sazonalidade.

\begin{tabular}{|c|c|c|c|c|}
\hline \multirow[b]{2}{*}{ Regiōes } & \multicolumn{2}{|c|}{ Análise de Regressão } & \multicolumn{2}{|c|}{ Estimativas dos parâmetros } \\
\hline & Valores de F & $\bar{R}^{2}$ & SAZ & $\overline{L F}$ \\
\hline Araçatuba & 65,590 * & 0,8898 & $-0,879(-3,38)^{*}$ & $-1,481(-8,06)^{\star}$ \\
\hline Bauru/Marilia & 143,212 * & 0,9467 & $-0,785(-4,61)^{\star}$ & $-1,467(-12,19)^{\star}$ \\
\hline Barretos/SJRP & $123,520^{*}$ & 0,9387 & $-0,670(-3,49)^{\star}$ & $-1,609(-11,87)^{*}$ \\
\hline Presidente Prudente & $47,557^{*}$ & 0,8534 & $-0,837(-2,89)^{\star \star}$ & $-1,402(-6,85)^{\star}$ \\
\hline Três Lagoas & $73,469 *$ & 0,9006 & $-0,785(-3,39)^{\star}$ & $-1,417(-8,66)^{\star}$ \\
\hline Triângulo Mineiro & 62,999 * & 0,8857 & $-0,848(-3,16)^{*}$ & $-1,521(-8,01)^{\star}$ \\
\hline Campo Grande & $52,107^{*}$ & 0,8647 & $-0,872(-3,35)^{*}$ & $-1,277(-6,93)^{\star}$ \\
\hline Goiânia & 59,094 * & 0,8790 & $-0,653(-2,72)^{\star \star}$ & $-1,359(-8,00)^{\star}$ \\
\hline Norte do Paraná & 124,356 * & 0,9391 & $-0,681(-4,56)^{*}$ & $-1,181(-11,17)^{*}$ \\
\hline
\end{tabular}

Observa-se na tabela 4, através do valor de $F$, que todas as regressões foram altamente significativas e apresentaram $\bar{R}^{2}$ elevado, indicando que o modelo explica grande parte da variância do componente aleatório da base no mês de vencimento, ou seja, seu risco.

As variáveis para sazonalidade foram todas significativas, indicando que o risco de base difere para os contratos com mês de vencimento no período da safra e da entressafra da oferta de gado bovino para abate. Uma vez que os coeficientes apresentaram-se todos negativos, pode-se concluir que o risco de base é menor para os contratos com vencimento na safra em relação àqueles que vencem na entressafra. Considerando-se que, durante o período de safra, existe um volume maior de informações sobre as condições de oferta e demanda de gado bovino do que no periodo da entressafra, neste último, os 
preços à vista e futuro são mais afetados pela chegada de novas informações ao mercado, que afetam a porção aleatória de variação da base e, portanto, é compreensivel que o risco seja maior para os contratos com vencimento no período da entressafra.

Em todas as regiões consideradas, as variáveis para liquidação financeira foram altamente significativas e negativas, indicando que após sua introdução houve uma redução do risco de base durante o mês de vencimento do contrato futuro. De acordo com os resultados para a variância da base na semana de vencimento, esse resultado era esperado, uma vez que os problemas e custos referentes à entrega física, que prejudicavam a convergência de preços e elevavam o risco de base, foram eliminados.

A redução percentual no risco de base durante o mês de vencimento do contrato, devido à introdução da liquidação financeira, foi calculada através da equação (22) para cada região e é apresentada na tabela 5.

Tabela 5. Redução percentual no risco de base para machos durante o mês de vencimento do contrato, para cada região.

\begin{tabular}{lccccccccc} 
& \multicolumn{10}{c}{ Regiōes } \\
\cline { 2 - 9 } & Araçatuba & Bauru/ & Barretos/ & Presidente & Trếs & Triângulo & Campo & Goiânia & Norte do \\
& & Marilia & SJRP & Prudente & Lagoas & Mineiro & Grande & Paraná \\
\hline $\begin{array}{l}\text { Reduçōes } \\
\text { \% no risco }\end{array}$ & 77,26 & 76,94 & 79,99 & 75,39 & 75,76 & 78,15 & 72,11 & 74,31 & 69,30 \\
\hline
\end{tabular}

Fonte: tabela 4.

Nota-se que a redução no risco de base devido à introdução da liquidação financeira foi bastante próxima para todas as regiōes. Apenas Norte do Paraná apresentou menor redução no risco de base, após a mudança na forma de liquidação, possivelmente em função de características próprias daquele mercado. 
Os resultados das regressões para fêmeas em cada região podem ser observados na tabela 6 . Os valores dos testes $F$ para as regressões foram significativos a $1 \%$ e o valor dos coeficientes das regressões ajustados para graus de liberdade foram elevados, indicando que o modelo utilizado para explicar a mudança no desvio padrão da base no mês de vencimento do contrato foi apropriado para esse fim.

Tabela 6. Resultados das regressões do desvio padrão da base para fêmeas no mês de vencimento do contrato em função da liquidação financeira $e$ sazonalidade.

\begin{tabular}{|c|c|c|c|c|}
\hline \multirow[b]{2}{*}{ Regiōes } & \multicolumn{2}{|c|}{ Análise de regressão } & \multicolumn{2}{|c|}{ Estimativas dos parâmetros } \\
\hline & Valores de F & $\bar{R}^{2}$ & SAZ & $\overline{L F}$ \\
\hline Araçatuba & 92,699 * & 0,9198 & $-0,601(-3,25)^{\star}$ & $-1,324(-10,13)^{*}$ \\
\hline Bauru/Marília & $55,855 *$ & 0,8727 & $-0,755(-2,91)^{\star *}$ & $-1,393(-7,59)^{*}$ \\
\hline Barretos/SJRP & 71,086 * & 0,8975 & $-0,545(-2,43)^{\star \star *}$ & $-1,455(-9,15)^{\star}$ \\
\hline Presidente Prudente & 32,349 * & 0,7967 & $-0,783(-2,45)^{\star \star \star}$ & $-1,269(-5,61)^{*}$ \\
\hline Três Lagoas & 53,656 * & 0,8681 & $-0,799(-3,97)^{\star}$ & $-0,934(-6,57)^{*}$ \\
\hline Triângulo Mineiro & 92,909 * & 0,9199 & $-0,701(-3,52)^{*}$ & $-1,402(-9,96)^{*}$ \\
\hline Campo Grande & 73,589 * & 0,9007 & $-0,483(-2,25)^{\star * *}$ & $-1,437(-9,45)^{*}$ \\
\hline Goiânia & $78,019^{*}$ & 0,9059 & $-0,457(-2,20)^{\star}$ & $-1,439(-9,81)^{*}$ \\
\hline Norte do Paraná & 114,569 * & 0,9342 & $-0,469(-2,93)^{\star *}$ & $-1,323(-11,71)^{*}$ \\
\hline
\end{tabular}

Todos os coeficientes das variáveis utilizadas para detectar sazonalidade no risco de base foram negativos e significativos, indicando que o risco de base para fêmeas também apresentou-se menor para os contratos com vencimento na safra do que para aqueles que vencem na entressafra. 
Os coeficientes das variáveis para liquidação financeira também foram negativos e altamente significativos, indicando que o risco de base foi reduzido para fêmeas, durante o mês de vencimento dos contratos, para todas as regiões consideradas no estudo, após a mudança na forma de liquidação. A redução percentual no risco de base para o cross hedging, durante o mês de vencimento do contrato, em cada região, pode ser observada na tabela 7 .

Tabela 7. Redução percentual no risco de base para fêmeas durante o mês de vencimento do contrato, para cada região.

\begin{tabular}{lccccccccc} 
& \multicolumn{10}{c}{ Regiões } \\
\cline { 2 - 9 } & Araçatuba & Bauru/ & Barretos/ & Presidente & Três & Triângulo & Campo & Goiânia & Norte do \\
& & Marlia & SJRP & Prudente & Lagoas & Mineiro & Grande & Paraná \\
\hline $\begin{array}{l}\text { Reduçōes } \\
\text { \% no risco }\end{array}$ & 73,39 & 75,17 & 76,66 & 71,89 & 60,70 & 75,39 & 76,24 & 76,28 & 73,37 \\
\hline
\end{tabular}

Fonte: tabela 6.

Esperava-se que a redução percentual no risco de base no mês de vencimento do contrato tivesse sido maior para machos do que para fêmeas. Porém, comparando-se os resultados das tabelas 5 e 7, nota-se que isso não ocorreu para as regiōes de Campo Grande, Goiânia e Norte do Paraná. Poderse-ia argumentar que possivelmente esse resultado está relacionado a características próprias desses mercados, mas pesquisas futuras são necessárias para que se possa esclarecer os resultados obtidos. 
6.3. Resultados do estudo do impacto da introdução da liquidação financeira sobre o nivel médio da base na semana de vencimento do contrato

Para verificar se e como a introdução da liquidação financeira alterou os niveis médios da base na semana de vencimento do contrato futuro de boi gordo da BM\&F, verificou-se a igualdade das médias nos períodos anterior e posterior a ela, através do teste $t$. Os pares de médias foram testados de acordo com as hipóteses (16) na seção 5.1 e os resultados obtidos nos testes são apresentados na tabela 8.

Tabela 8. Base média na semana de vencimento dos contratos, antes e depois da introdução da liquidação financeira e resultados dos testes $t$.

\begin{tabular}{|c|c|c|c|c|c|c|}
\hline \multirow[b]{2}{*}{ Regiōes } & \multicolumn{3}{|c|}{ Machos } & \multicolumn{3}{|c|}{ Fêmeas } \\
\hline & $\bar{B}_{\text {antes }}$ & $\overline{\bar{B}}_{\text {depois }}$ & Valores de $t$ & $\overline{\bar{B}}_{\text {antes }}$ & $\overline{\bar{B}}_{\text {depois }}$ & Valores de $t$ \\
\hline Araçatuba & $-3,48$ & 0,08 & $-3,88^{* * *}$ & $-8,18$ & $-3,90$ & $-3,39^{\star \star \star}$ \\
\hline Bauru/Marilia & $-3,27$ & 0,08 & $-3,59 * * *$ & $-8,30$ & $-4,11$ & $-3,07^{\star * * *}$ \\
\hline Barretos/SJRP & $-3,51$ & 0,16 & $-3,57^{* * *}$ & $-7,84$ & $-3,76$ & $-3,28$ *** \\
\hline Presidente Prudente & $-3,72$ & $-0,01$ & $-3,63^{* * *}$ & $-8,01$ & $-3,84$ & $-2,85^{* * * *}$ \\
\hline Três Lagoas & $-5,46$ & $-1,15$ & $-3,95^{* \star *}$ & $-9,64$ & $-5,03$ & 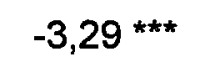 \\
\hline Triângulo Mineiro & $-5,02$ & $-0,98$ & $-4,24^{* * *}$ & $-8,66$ & $-4,53$ & $-3,15^{* * *}$ \\
\hline Campo Grande & $-6,03$ & $-1,37$ & $-3,26$ *** & $-9,95$ & $-5,02$ & $-3,00^{\star \star \star * *}$ \\
\hline Goiânia & $-5,93$ & $-1,13$ & $-4,96 * * * *$ & $-9,79$ & $-4,79$ & $-3,39 * * *$ \\
\hline Norte do Paraná & $-5,09$ & $-0,61$ & $-4,34 * * *$ & $-8,92$ & $-4,24$ & $-3,96 * * *$ \\
\hline
\end{tabular}

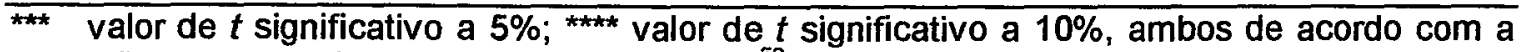
obtenção do valor crítico proposto por Cochran ${ }^{52}$, citado por Hoffmann (1980).

52 COCHRAN, W.G. Approximate significance levels of the Behrens-Fisher test. Biometrics, v.20, p. 191-195, 1964. 
Os resultados apresentados na tabela 8 indicam que a média da base na semana de vencimento do contrato futuro foi alterada, após a introdução da liquidação financeira, uma vez que todos os testes foram significativos. Apesar de as amostras serem pequenas e a normalidade da distribuição ser questionável para utilizar o teste $t$, pode-se observar pelos valores da referida tabela que houve uma redução expressiva no valor absoluto da média da base na semana de vencimento do contrato futuro, após a introdução da liquidação financeira.

Essa redução no valor absoluto ocorreu no sentido da melhor convergência dos preços à vista e futuro na semana de vencimento do contrato, uma vez que a base se aproximou mais de zero após a introdução da liquidação financeira. Nota-se, ainda, que a melhor convergência de preços ocorreu nas regiões que compõem o cálculo do IBG, para animais machos.

Conforme esperado, a melhor convergência dos preços ocorreu para os animais especificados no contrato. Da mesma forma, era esperado que as regiōes que compõem o cálculo do IBG apresentassem melhor convergência, uma vez que este representa uma média de seus preços à vista, enquanto as regiões não incluídas nesse cálculo apresentam movimentos de oferta $e$ demanda locais, não refletidos no IBG. Contudo, uma vez que para todas as regiôes a variância da base foi reduzida e os preços à vista e futuro apresentaram melhor convergência, a base tornou-se mais previsivel.

As figuras 4, 5, 6 e 7 mostram a base na semana de vencimento de cada contrato, para cada região e para cada sexo e sua aproximação de zero, indicando a melhor convergência dos preços à vista e futuro, após a introdução da liquidação financeira. É possível observar que a base está mais próxima de zero para todas as regiões e para ambos os sexos, após o contrato com vencimento em agosto de 1995 , quanto foi realizada a primeira liquidação financeira do contrato futuro de boi gordo da BM\&F. 
Figura 4. Base para machos na semana de vencimento de cada contrato, para as regiões que compõem o cálculo do IBG.

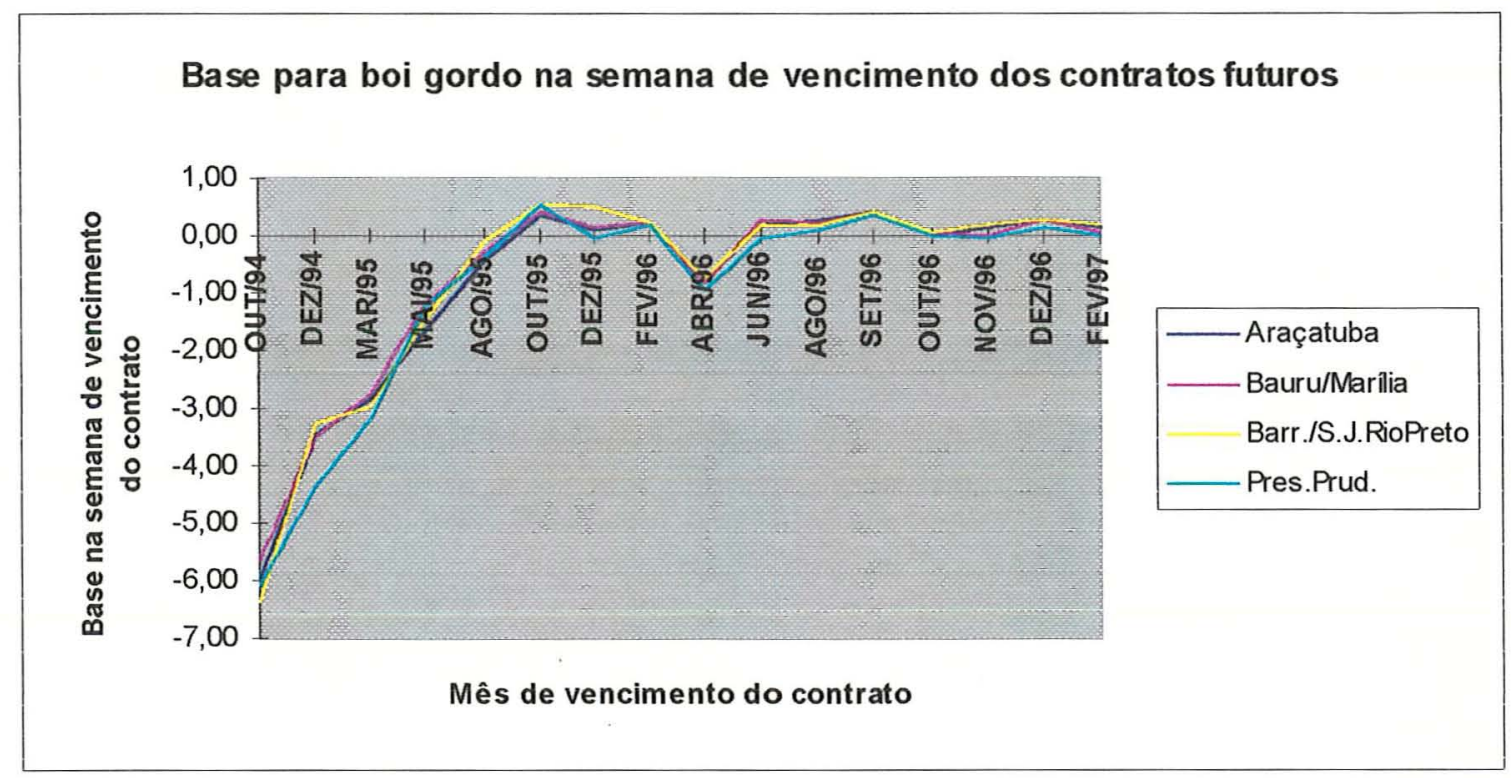

Fonte: BM\&F e FEALQ.

Figura 5. Base para machos na semana de vencimento de cada contrato, para as regiões que não compõem o cálculo do IBG.

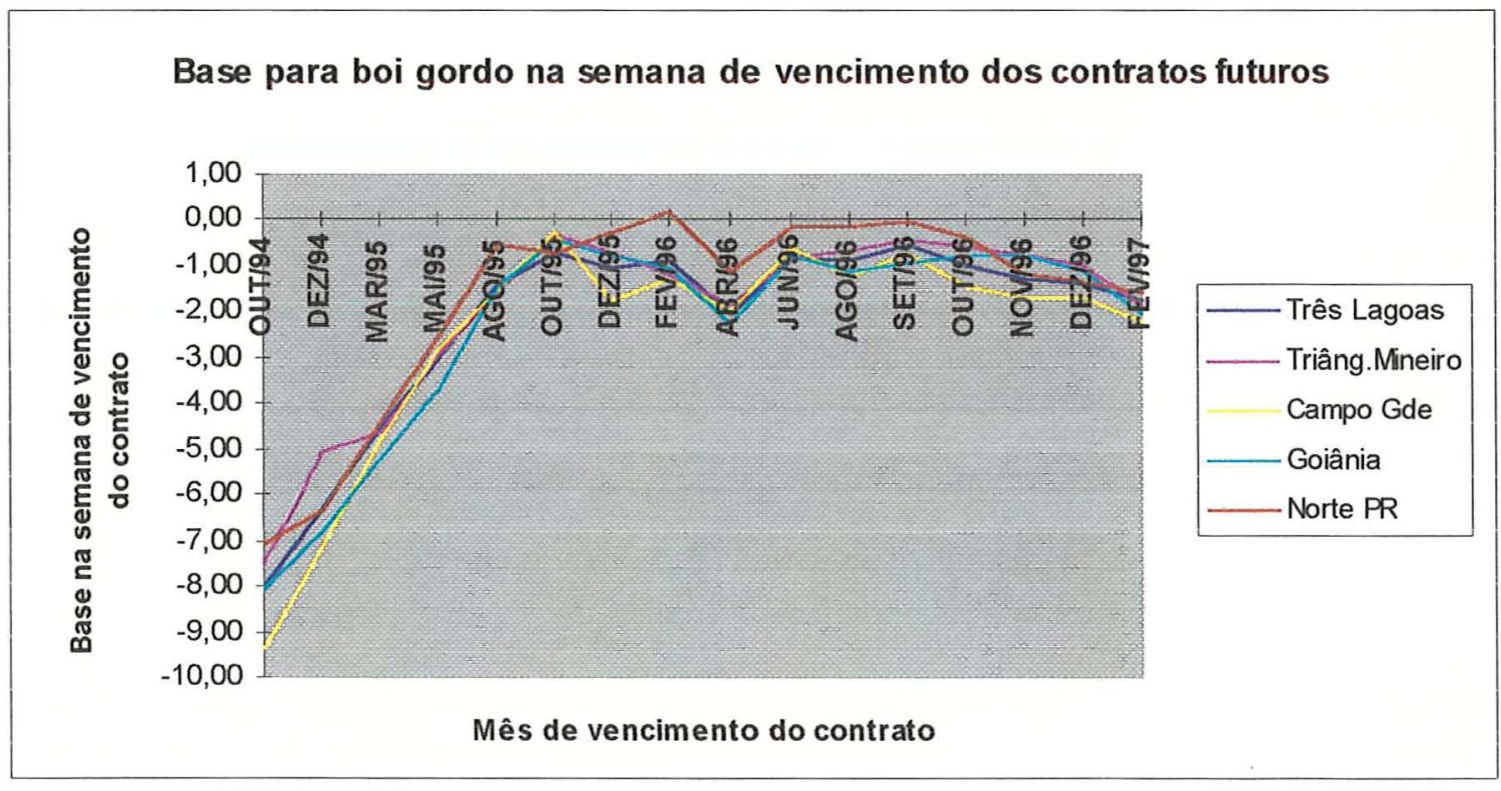

Fonte: BM\&F e FEALQ. 
Figura 6. Base para fêmeas na semana de vencimento de cada contrato, para as regiões que compõem o cálculo do IBG.

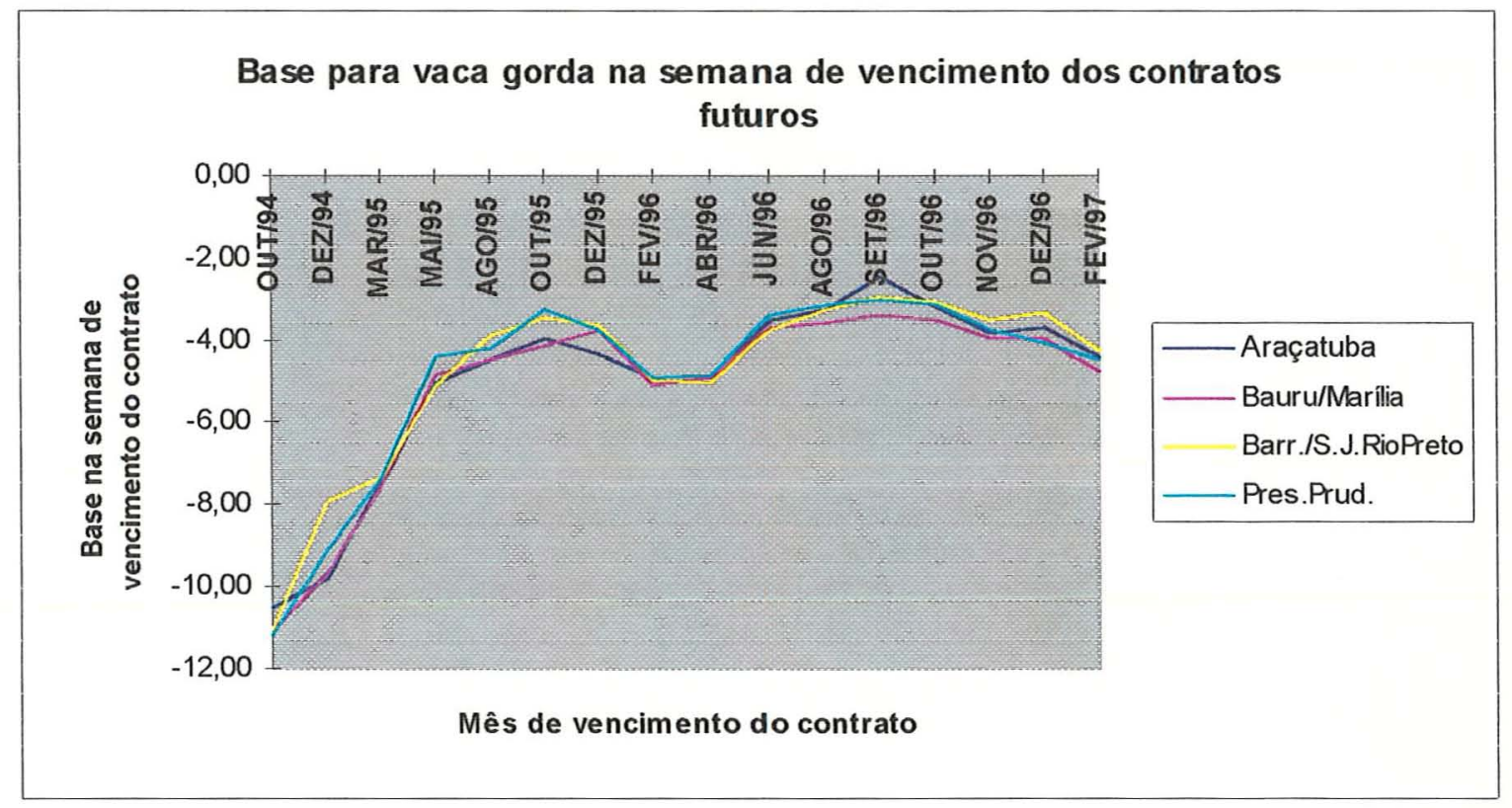

Fonte: BM\&F e FEALQ.

Figura 7. Base para fêmeas na semana de vencimento de cada contrato, para as regiões que não compõem o cálculo do IBG.

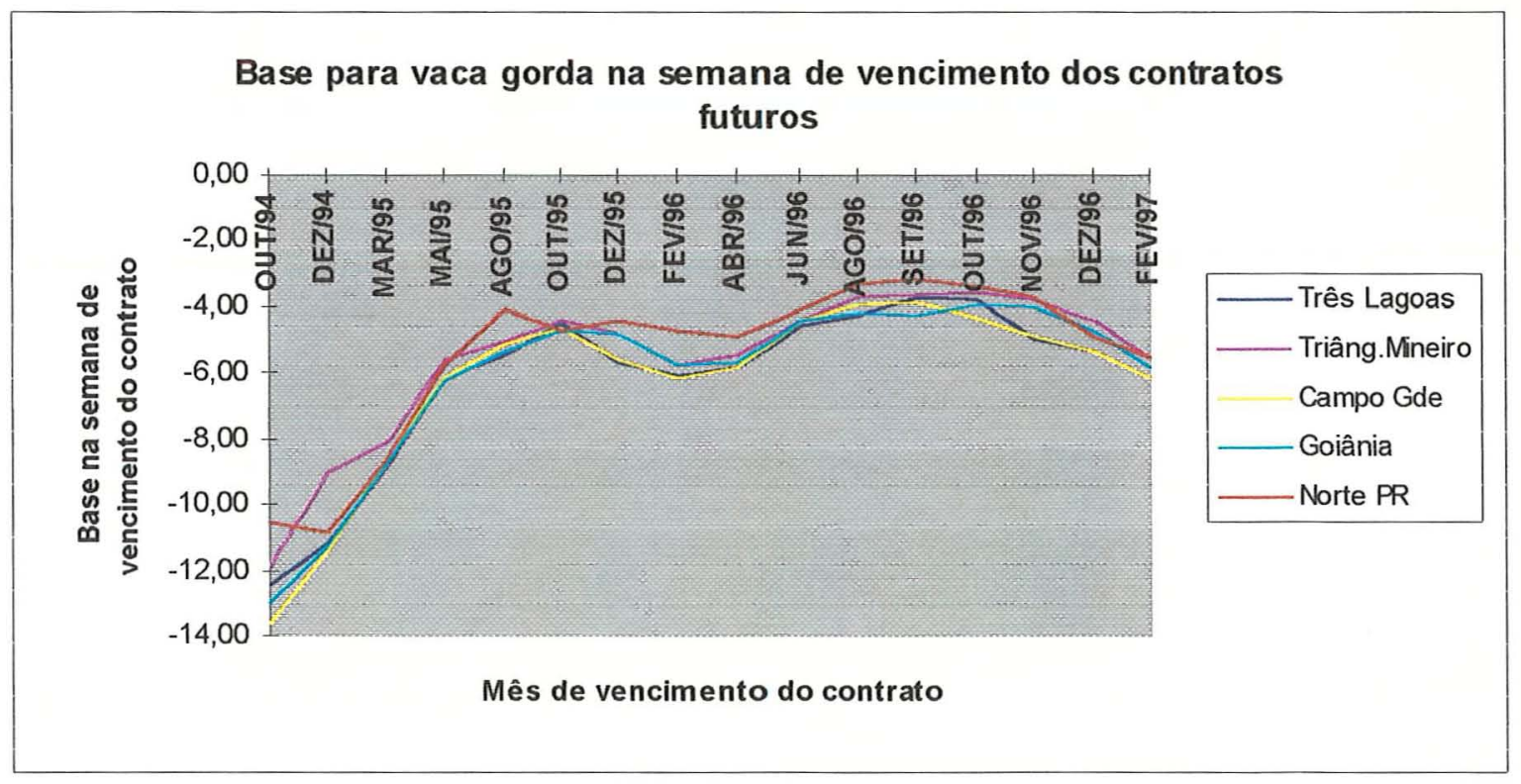

Fonte: BM\&F e FEALQ. 
O Plano Real foi implantado em julho de 1994 e sua adoção levou à redução dos índices de inflação e estabilização da economia. Provavelmente, esse novo cenário econômico tenha auxiliado o processo de convergência entre os preços à vista e futuro desde então, pois a inflação em patamares mais baixos facilita o processo de descoberta dos preços futuros.

Entretanto, é interessante notar que, embora a liquidação financeira tenha ocorrido efetivamente para o contrato com vencimento em agosto de 1995, a base já vinha se aproximando de zero desde o contrato com vencimento em outubro de 1994.

Nesse contexto, torna-se importante salientar que, durante a entressafra da oferta de gado bovino para abate no ano de 1994, houve um aumento da demanda por carne no varejo, em função da alteração na distribuição de renda da população, após a implantação do Plano Real. Adicionalmente, observa-se que a cada plano econômico, ocorrem ações especulativas, apostando num eventual fracasso das medidas determinadas pelo governo. Este cenário de incertezas e expectativas geradas pela adoção do novo plano de estabilização da economia, nos meses seguintes à sua implantação, coincidiu com a entressafra da oferta de bovinos para abate.

Nota-se pelas figuras 4, 5, 6 e 7 que, nos contratos com vencimento nos meses de outubro e dezembro de 1994, a base é sensivelmente maior em valor absoluto do que nos demais meses de vencimento. Como os preços à vista utilizados no presente estudo só estavam disponiveis a partir do contrato futuro com vencimento em outubro de 1994, não foi possível identificar se tal fato é decorrente dos efeitos do Plano Real na economia ou se os valores da base, anteriores ao referido vencimento, encontravam-se nesses patamares, devido aos problemas com a entrega física para liquidar os contratos. Adicionalmente, pode-se considerar o efeito de ambos os fatores em conjunto.

Desta forma, utilizando-se outra fonte de preços à vista, levantados pelo Instituto de Economia Agrícola (IEA) e Coordenadoria de Assistência Técnica 
Integral (CATI), foi possível construir a série da base na semana de vencimento a partir de 1992 e observar que seus valores para os contratos de outubro e dezembro de 1994 realmente se ampliaram em relação aos niveis da base anteriores e posteriores a esses vencimentos, antes da introdução da liquidação financeira (ver Apêndice 7).

Uma vez que os vencimentos de outubro e dezembro de 1994 correspondem a metade do número de contratos utilizados para o período anterior à introdução da liquidação financeira, poder-se-ia estar superestimando a variância da base nesse período, pela utilização dos valores correspondentes àqueles vencimentos. Assim, toda a variação da base estaria sendo atribuída às condições de liquidação do contrato por entrega física, quando, na verdade, os efeitos do Plano Real na economia podem também ter afetado os valores da base durante a entressafra de 1994.

Portanto, para maior rigor dos resultados obtidos no presente estudo, os testes para igualdade de variâncias da base, descritos por (10) e os testes para igualdade das médias da base, apresentados em (16), ambos na semana de vencimento dos contratos, foram realizados novamente, utilizando-se os preços à vista do IEA/CATI. As hipóteses testadas, bem como os métodos utilizados, foram os mesmos descritos na seção 5.1 .

Uma vez que se dispõe dos preços à vista do IEA/CATI apenas para machos, nas regiōes de Araçatuba, Bauru, Marília, Barretos, São José do Rio Preto e Presidente Prudente, não há observações suficientes para estimar a regressão que permite isolar o efeito do sexo dos animais sobre o risco de base e verificar se este difere entre regiões. Além disso, como nos anos anteriores a 1994 o mercado futuro de boi gordo apresentava baixa liquidez, as séries da base durante os meses de vencimento do contrato apresentam falhas, o que impossibilita a estimação do risco. Desta forma, torna-se importante esclarecer que essas limitações inviabilizaram a utilização desta fonte de dados no presente estudo. 
Entretanto, os preços à vista do IEA/CATI, disponíveis a partir de 1992, foram utilizados como fonte adicional de dados, para maior rigor dos resultados obtidos no estudo. Desta forma, o número de contratos utilizados para calcular a base antes da introdução da liquidação financeira aumentou de 4 para $9^{53}$, e no período posterior, manteve-se em 12. O procedimento adotado para trazer os preços para o valor presente e convertê-los em dólares americanos foram os mesmos estabelecidos na seção 5 , onde se descrevem os dados utilizados no presente estudo.

Os resultados obtidos com a utilização dos preços à vista do IEA/CATI são apresentados no Apêndice 8 e não diferem daqueles obtidos no estudo com os dados do CEPEA/FEALQ, exceto quanto ao nivel de significância de alguns testes. Estes resultados mostram que a introdução da liquidação financeira reduziu efetivamente o risco de base para o contrato futuro de boi gordo em comparação com o período em que a entrega física era obrigatória e que os niveis da base também foram reduzidos em valor absoluto, indicando uma melhor convergência entre os preços à vista e futuro, após a mudança na forma de liquidação.

Pode-se concluir desta forma que, apesar do valor absoluto da base ter aumentado consideravelmente nos meses de outubro e dezembro de 1994 em relação aos vencimentos anteriores, a utilização destas observações, que compõem metade da amostra da base no período anterior à introdução da liquidação financeira, não invalida os resultados obtidos no presente estudo. Além disso, cabe observar que, possivelmente, os efeitos do Plano Real na economia acentuaram os problemas causados pela entrega física e falta de liquidez no mercado futuro de boi gordo durante a entressafra 1994.

\footnotetext{
${ }^{53}$ Os preços à vista para a região de Marília começaram a ser levantados pelo IEA/CATI, a partir de 1994, mas mesmo assim os testes para esse mercado foram realizados. Para a região de Presidente Prudente, existe uma falha na série de preços à vista da referida fonte em abril de 1993 e, portanto, o contrato desse vencimento não pôde ser utilizado. Assim, apenas 8 contratos foram utilizados para calcular as bases antes da introdução da liquidação financeira nessa região.
} 


\section{CONCLUSÕES}

A introdução da liquidação financeira para o contrato futuro de boi gordo da BM\&F fez-se acompanhar da redução no risco de base para todas as regiões consideradas no estudo, bem como para machos e fêmeas. Os resultados dos testes sobre a variância da base na semana de vencimento do contrato futuro indicaram que ela foi significativamente menor, depois que os contratos passaram a ser liquidados financeiramente.

Com a eliminação dos custos e problemas relacionados à entrega física, não só as regiões que compõem o cálculo do IBG foram beneficiadas pela redução do risco de base, mas também aquelas que não o integram. Esses resultados tornam-se importantes, na medida em que demonstram que os benefícios advindos da introdução da liquidação financeira estendem-se às demais regiões de criação de gado bovino economicamente importantes e que não compõem o cálculo do Indicador. Assim, agentes de todo o país podem sentir-se estimulados a participar do mercado futuro de boi gordo e não apenas aqueles estabelecidos no Estado de São Paulo.

De acordo com as considerações teóricas, a redução no risco de base devido à introdução da liquidação financeira pode ser atribuída à eliminação dos custos e problemas relacionados à entrega física, que prejudicavam a convergência dos preços à vista e futuro e levavam a flutuações imprevisíveis da base. Adicionalmente, o risco do hedging pode ter sido reduzido porque a liquidação financeira é feita por um índice de preços no mercado à vista e não mais pela obrigatoriedade da entrega física. Como esses índice pode tornar-se 
mais previsivel porque se espera que a média dos preços de diversos mercados varie menos do que o preço da mercadoria com padrões mínimos para entrega em um mercado específico, a previsibilidade da base também melhoraria. É importante enfatizar, além disso, que a geração de novas informações, através da divulgação do IBG, fornece transparência ao mercado, auxiliando o processo de descoberta de preço e melhorando as condições para realização do hedging.

A análise do volume de contratos negociados revelou que este aumentou expressivamente após a introdução da liquidação financeira, sugerindo que ela está fortemente associada ao aumento da liquidez do mercado futuro de boi gordo da BM\&F. Desta forma, além da redução no risco de base, a liquidação financeira pode ter estimulado a negociação dos contratos pela liberação da obrigatoriedade da entrega no vencimento. Deve-se salientar, entretanto, que a BM\&F vem promovendo programas de incentivo ao desenvolvimento do mercado futuro de agropecuários, o que pode estar contribuindo, adicionalmente, para o aumento do número de contratos negociados. Além disso, conforme esperado pela BM\&F, como os contratos são liquidados por diferença, envolvendo o mercado físico somente em casos especiais, os participantes não habituados a negociar nesse mercado, sentemse mais à vontade para operar o contrato futuro de boi gordo.

Assim, pode-se concluir que a introdução da liquidação financeira levou à redução do risco de base, melhorando as condições para realização do hedging e incentivando a utilização do contrato futuro de boi gordo pelos agentes do mercado. O desenvolvimento de um mercado futuro de boi gordo com elevada liquidez, concorre para a modernização da estrutura financeira e de comercialização da bovinocultura de corte no Brasil.

Os resultados do modelo de regressão para isolar o impacto da introdução da liquidação financeira sobre o risco de base, de outras modificações adotadas conjuntamente e verificar se este difere entre regiões e 
entre sexos, mostraram que o risco do hedging foi reduzido em $76,08 \%$, pela mudança na forma de liquidação. Nota-se por este valor que a redução foi bastante expressiva, indicando que a liquidação financeira efetivamente promoveu melhorias na realização do hedging, auxiliando o desenvolvimento do mercado futuro de boi gordo.

Além disso, o sinal do coeficiente da variável para representar sexo indicou que o risco de base é menor para bois gordos do que para vacas gordas, uma vez que o contrato futuro estabelece animais machos como objetos de negociação. Desta forma, confirmando empiricamente as considerações teóricas, o risco do hedging é menor do que o risco do cross hedging, pois este último conta com o risco adicional da diferença de preço entre 0 ativo hedgeado e aquele estabelecido no contrato.

As variáveis para identificar cada região considerada no estudo mostraram, através dos testes de seus coeficientes, que o risco de base não difere estatisticamente entre as regiōes que compōem o cálculo do IBG. Contudo, nos testes para comparar estas àquelas que não integram este cálculo, o risco de base apresentou-se estatisticamente maior em alguns mercados fora do Estado de São Paulo.

Conforme esperado, se o IBG representa uma média de preços das regiões do Estado de São Paulo, os riscos de base nestas localidades realmente não deveriam diferir, pois cada uma compõe uma porção do Indicador. Além disso, esperava-se também que, nas regiōes que compõem o IBG, o risco de base fosse menor em relação aos demais mercados. Isso de fato ocorreu, apesar da diferença não ter sido estatisticamente significativa em todos os casos.

O estudo sobre a variabilidade da base no mês de vencimento do contrato futuro confirmou os resultados obtidos com os estudos da base na semana de vencimento do contrato. Os resultados das regressões indicaram que o risco de base foi reduzido para todas as regiões, para machos e fêmeas, 
após a introdução da liquidação financeira. As variáveis representando sazonalidade mostraram que o risco do hedging foi maior para os contratos com vencimento nos meses da entressafra da oferta de gado bovino para abate, em relação aos meses de safra. Nestes últimos, há maior volume de informações disponiveis no mercado, o que facilita a previsão dos preços futuros e, conseqüentemente, da base, reduzindo o risco.

Deve-se salientar a importância destes resultados no sentido de esclarecer e advertir os agentes do mercado de que o risco de base durante o mês de vencimento é maior para os contratos que vencem nos meses de entressafra da oferta de gado bovino para abate em relação aos demais meses de vencimento. Por isso, a administração do hedging durante esses meses merece especial atenção, a fim de obter-se a melhor performance com a operação no mercado.

Os resultados da análise dos níveis médios da base na semana de vencimento do contrato mostraram que estes são significativamente diferentes antes e depois da introdução da liquidação financeira. Após a mudança na forma de liquidação, os valores da base aproximaram-se mais de zero para machos e fêmeas, em todas as regiões consideradas no estudo. Isso indica que a introdução da liquidação financeira promoveu efetivamente redução no risco de base, via melhoria na convergência dos preços à vista e futuro. Adicionalmente, pode-se concluir que, se estes preços estão convergindo melhor depois da mudança na forma de liquidação, o IBG está representando adequadamente os preços no mercado à vista. Assim, conforme apontado pela BM\&F quando da adoção da liquidação financeira, o IBG dificulta a distorção de preços no vencimento e fornece maior eqüidade para compradores e vendedores.

O sucesso de um contrato futuro depende de os preços à vista e futuro convergirem para o mesmo valor. Nesse contexto, a redução do risco de base e sua melhor previsibilidade são fundamentais para melhorar a efetividade do 
hedging, tornando os contratos futuros mais úteis aos agentes do mercado, como veículo de administração de risco.

Finalmente, algumas considerações devem ser feitas em relação aos resultados obtidos no presente estudo. A primeira refere-se à carência de dados para realização do mesmo. Embora haja maior volume de dados para o período posterior à introdução da liquidação financeira, estes ainda podem ser complementados com o passar do tempo. Contudo, no que se refere ao período anterior, não há possibilidade de obter dados adicionais. Desta forma, os resultados estão baseados em amostras pequenas e de tamanhos diferentes. Entretanto, todos eles são altamente significativos e apontam para as mesmas conclusões, ou seja, todas as formas de análise indicaram que a introdução da liquidação financeira reduziu o risco de base, em todos os mercados considerados, para machos e fêmeas.

Em segundo lugar, a partir de julho de 1994, com a implantação do Plano Real, a inflação foi reduzida e as regras da economia tornaram-se mais estáveis, propiciando condições para melhor previsibilidade dos preços futuros e redução do risco de base. Desta forma, a redução do risco do hedging, além da introdução da liquidação financeira, pode estar ligada à estabilização da economia, condição essencial para o desenvolvimento dos mercados futuros, especialmente de commodities agropecuárias. 


\section{REFERÊNCIAS BIBLIOGRÁFICAS}

AMORIM, J.M. Os Fundos de Commodities. In: CURSO SOBRE COMERCIALIZAÇÃO DE COMMODITIES AGROPECUÁRIAS, 4, Piracicaba, 1994. Piracicaba: BM\&F; FEALQ; ESALQ, 1994. p.136-148.

BIALOSKORSKI NETO, S. Introdução ao mercado de futuros agropecuários. In: CURSO SOBRE COMERCIALIZAÇÃO DE COMMODITIES AGROPECUÁRIAS, 4, Piracicaba, 1994. Piracicaba: BM\&F; FEALQ; ESALQ, 1994. p.77-92.

BOLSA DE MERCADORIAS DE SÃO PAULO. Bolsa de Mercadorias de São Paulo 1917-1987. São Paulo: Laserprint Editorial, 1987. 149p.

BOLSA DE MERCADORIAS \& FUTUROS. Acompanhamento da Safra. São Paulo, n.22, 1994. 8p.

BOLSA DE MERCADORIAS \& FUTUROS. Relatório anual 1991/programa de trabalho e proposta orçamentária 1992. São Paulo, 1991.

BOLSA DE MERCADORIAS \& FUTUROS. Relatório anual 1992/programa de trabalho 1993. São Paulo, 1992. 
BOLSA DE MERCADORIAS \& FUTUROS. Relatório anual 1993/programa de trabalho 1994. São Paulo, 1993.

BOLSA DE MERCADORIAS \& FUTUROS. Relatório anual 1995/programa de trabalho 1996. São Paulo, 1995.

BOLSA DE MERCADORIAS \& FUTUROS. Síntese de dados. São Paulo, 1996. 50p.

BOLSA DE MERCADORIAS \& FUTUROS. Sintese de dados. São Paulo, 1997. 44p.

BROWN, M.B.; FORSYTHE, A.B. Robust tests for the equality of variances. Journal of the American Statistical Association, v.69, n.346, p.364-467, June 1974.

CASTELINO, M.G. Basis volatility: implications for hedging. The Journal of Financial Research, v.12, n.2, p. 157-172, 1989.

CHICAGO MERCANTILE EXCHANGE INSIGHTS Understanding the new volume weighted feeder cattle cash settlement index. Chicago, 1993, 4 p.

CONOVER, W.J.; JOHNSON, M.E.; JOHNSON, M.M. A comparative study for homogeneity of variance, with applications to the outer continental shelf bidding data. Technometrics, v.23, n.4, p. 351-361, Nov. 1981. 
DE ZEN, S. Integração entre os mercados de boi gordo e de carne bovina no centro-sul do Brasil. Piracicaba, 1997. Dissertação (Mestrado) - Escola Superior de Agricultura "Luiz de Queiroz".

ELAM, E. Estimated hedging risk with cash settlement feeder cattle futures. Western Journal of Agricultural Economics, v.13, n.1, p. 45-52, July 1988.

FRICK, O. O mercado futuro de boi gordo em nova versão. Preços Agrícolas, v.107, p. 8-9, nov. 1995.

FERREIRA, A.; HORITA, N. BM\&F: a história do mercado futuro no Brasil. São Paulo: Bolsa de Mercadorias e Futuros e Cultura Editores Associados, 1996. $474 p$.

GARBADE, K.D.; SILBER, W.L. Cash settlement of futures contracts: an economic analysis. The Journal of Futures Markets, v.3, n.4, p. 451-472, 1983.

GARCIA, P.; LEUTHOLD, R.M.; SARHAN, M.E. Basis risk: measurement and analysis of basis fluctuations for selected livestock's markets. The American Journal of Agricultural Economics, v.66, n.4, p. 499-504, Nov. 1984.

GARCIA, P.; SANDERS, D.R. Ex ante basis risk in live hog futures contract: has hedgers' risk increased? The Journal of Futures Markets, v.16, n.4, p. 421-440, 1996. 
GEPPERT, J.M. A statistical model for the relationship between futures contract hedging effectiveness and investment horizon length. The Journal of Futures Markets, v.15, n.5, p. 507-536, 1995.

HALVORSEN, R.; PALMQUIST, R. The interpretation of dummy variables in semilogarithmic equations. American Economic Review, v.70, n.3, p. 474475, June 1980.

HOFFMANN, R. Estatística para economistas. São Paulo: Livraria Pioneira Editora, 1980. 379p.

HSIANG, D.; LIEN, D. Cash settlement provisions on futures markets. The Journal of Futures Markets, v.9, n.3, p. 263-270, 1989.

HULL, J. Introdução aos mercados futuros e de opções. 2. ed. São Paulo: Bolsa de Mercadorias e Futuros e Cultura Editores Associados, 1996. 448 p.

JONES, F.J. The economics of futures and options contracts based on cash settlement. The Journal of Futures Markets, v.2, n.1, p. 63-82, 1992.

KAHL, K.H.; HUDSON, M.A.; WARD, C.E. Cash settlement issues for live cattle contracts. The Journal of Futures Markets, v.9, n.3, p. 237-248, 1989.

KENYON, D.; BAINBRIDGE, B; ERNST, R. Impact of cash settlement on feeder cattle basis. Western Journal of Agricultural Economics, v.16, n.1, p. 93105, July 1991. 
LEUTHOLD, R.M.; JUNKUS, J.C.; CORDIER; J.E. The theory and practice of futures markets. Massachusetts: Lexington Books, 1989. 410p.

LEUTHOLD, R.M. Cash settlement versus physical delivery: the case of livestock. The Review of Futures Markets, v.11, n.2, p. 175-183, 1992.

NETZ, J.S. An empirical test of the effect of basis risk on cash market positions. The Journal of Futures Markets, v.16, n.3, p. 289-311, 1996.

PAROUSH, J.; WOLF, A. Production and hedging decisions in the presence of basis risk. The Journal of Futures Markets, v.9, n.6, p. 547-563, 1989.

PIRRONG, S.C.; HADDOCK, D.; KORMENDI, R. et al. Grain futures contracts: an economic appraisal. In: KALO A. HINEMAN DELIVERY ISSUES SYMPOSIUM, Washington, 1991. Focus 1991. Washington: Commodity Futures Trading Commission, 1991. p.171-416.

RESENHA BM\&F. São Paulo, n.76, nov./dez. 1991.

RESENHA BM\&F. São Paulo, n.95, nov./dez. 1993. 86p.

RESENHA BM\&F. São Paulo, n.102, nov./dez. 1994. 106p.

RICH, D.R. Feeder cattle cash settlement: impacts on basis variability and behavior in selected U.S. markets. Urbana, 1990. 118p. Thesis (M.S.) University of Illinois. 
RICH, D.R.; LEUTHOLD, R.M. Feeder cattle cash settlement: hedging risk reduction or illusion? The Journal of Futures Markets, v.13, n.5, p. 497$514,1993$.

SCHROEDER, T.C.; MINTERT, J. Hedging feeder steers and heifers in the cash-settled feeder cattle futures market. Western Journal of Agricultural Economics, v.13, n.2, p. 316-326, Dec. 1988.

STADUTO, J.A.R. Os mercados de opções agrícolas: uma alternativa de financiamento para a agricultura. Viçosa, 1995. 133p. Dissertação (M.S.) Universidade Federal de Viçosa.

WILLIAMS, J. The economic function of futures markets. Cambridge: Cambridge University Press, 1986. 260p.

WORKING, H. Futures trading and hedging The American Economic Review, v.43, n.3, p.314-343, 1953. 


\section{APÊNDICE}




\section{APÊNDICE 1}

Contrato futuro cambial de boi gordo, lançado pela BM\&F em junho de 1991 


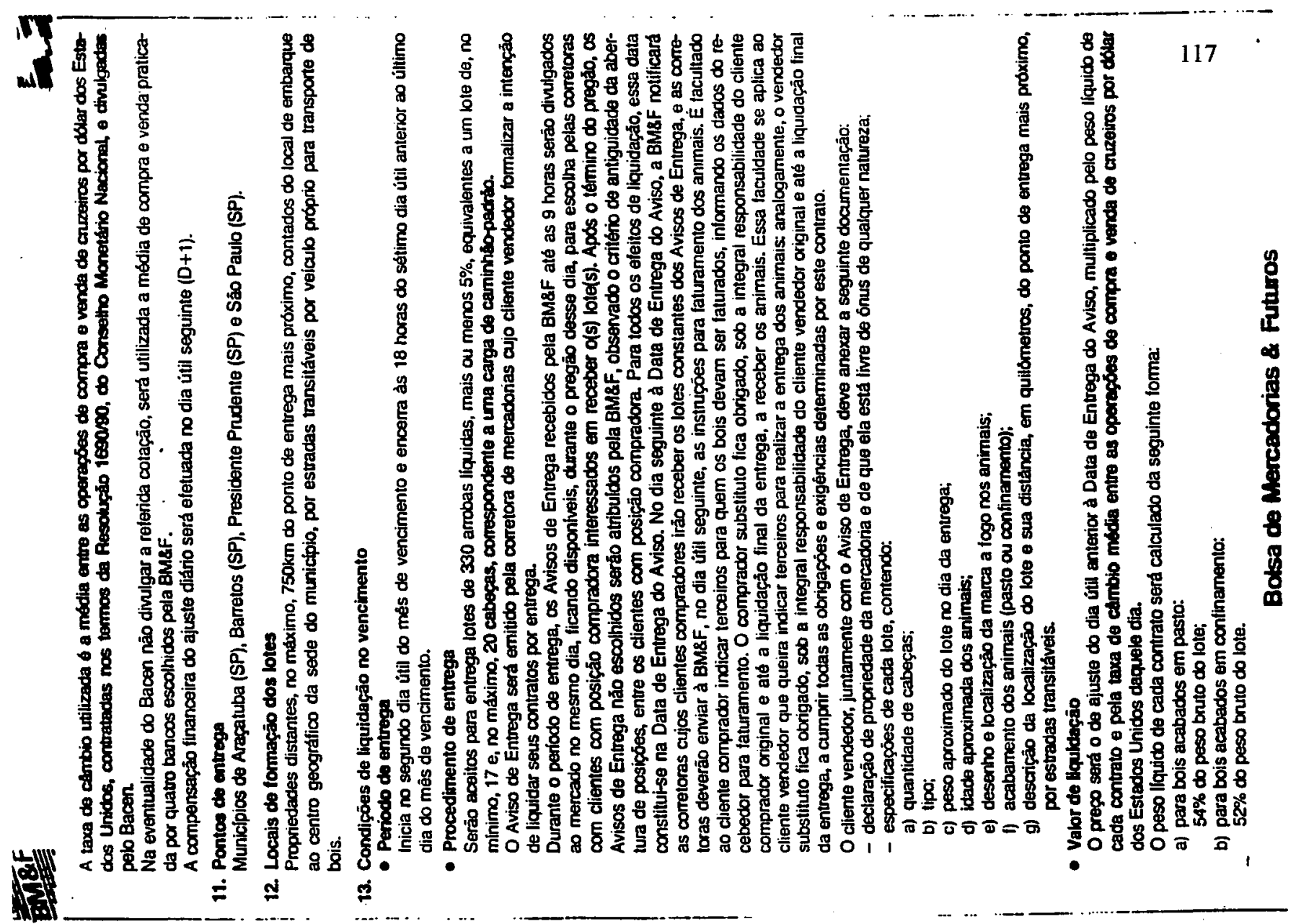

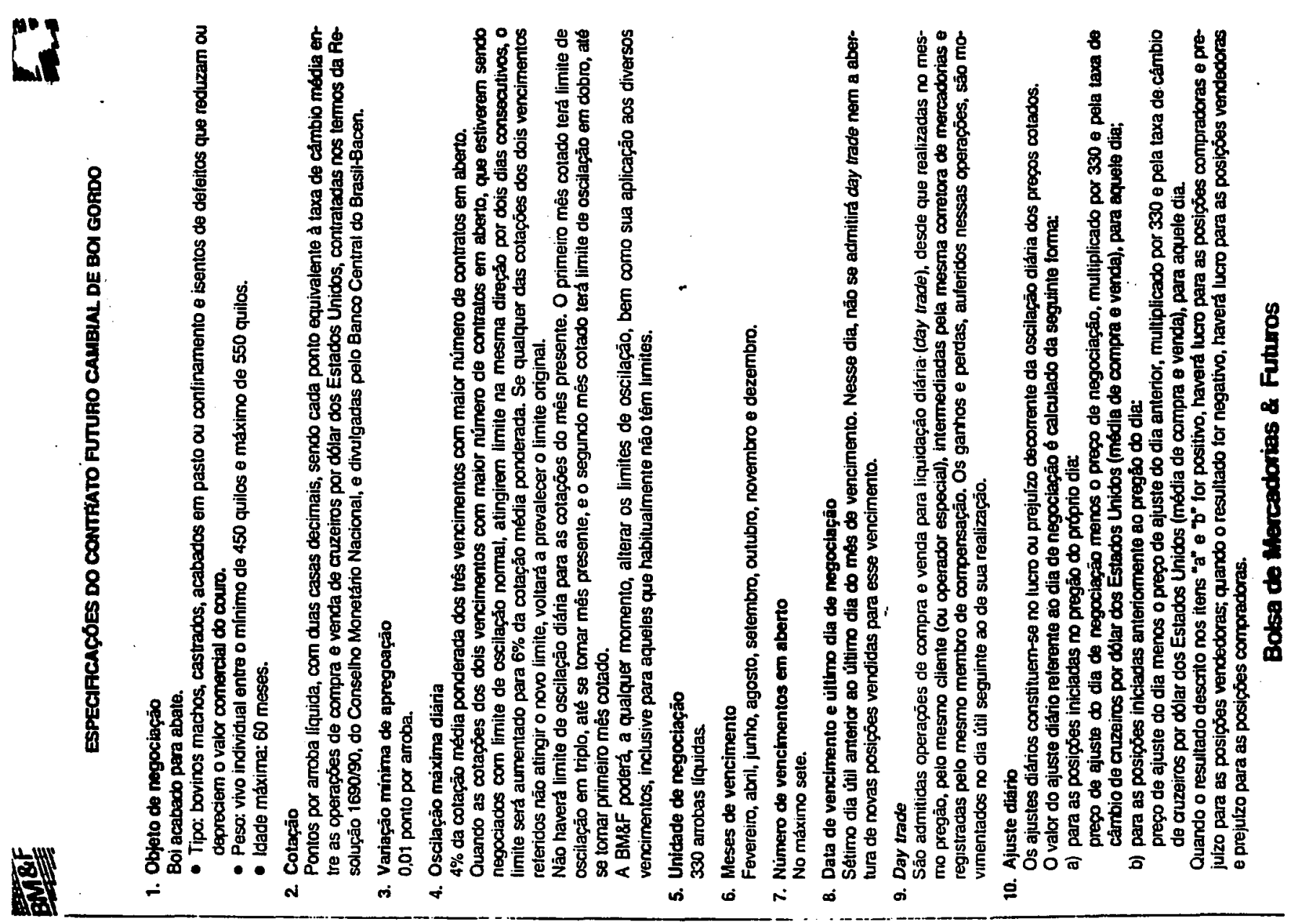



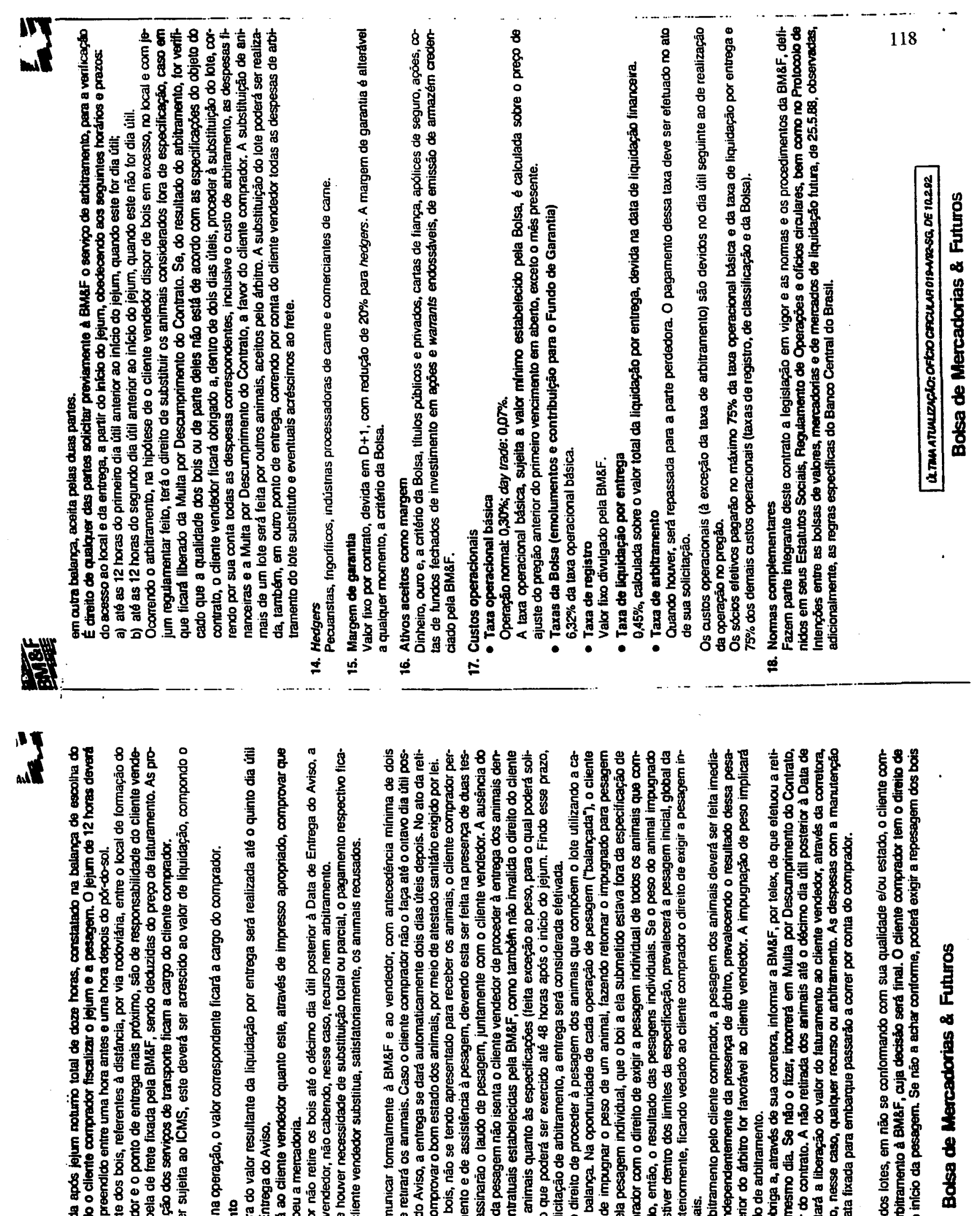

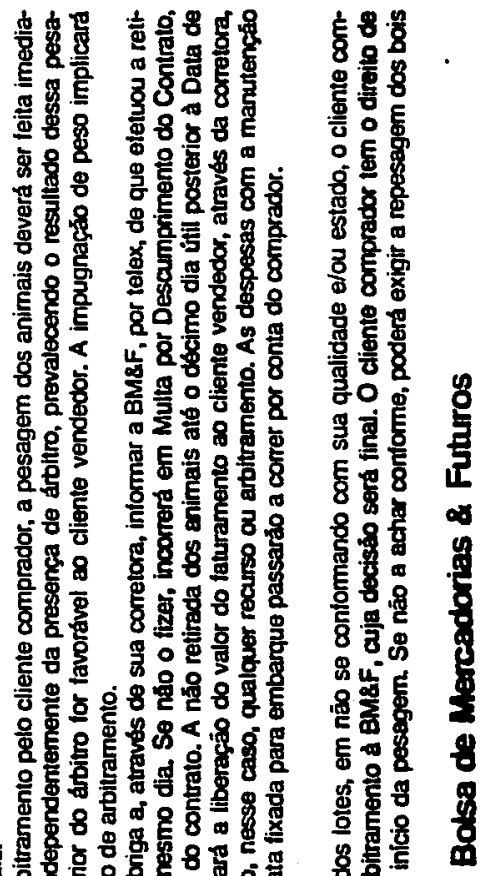

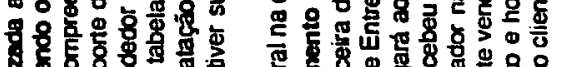

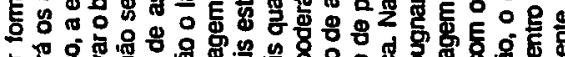
18: บำ 㴔

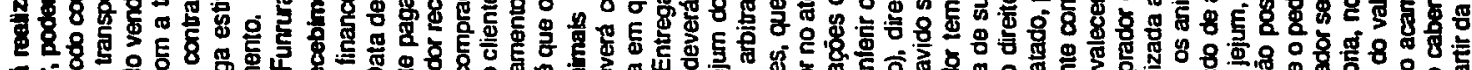
등흘

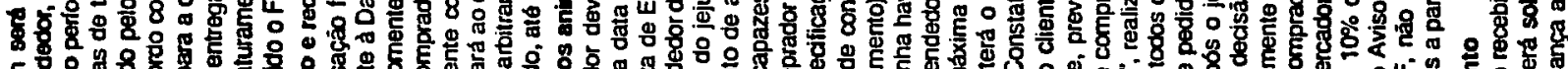

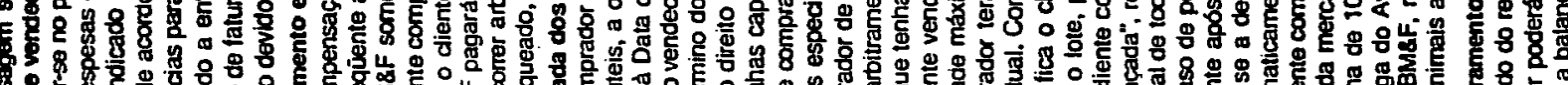
\% 웅

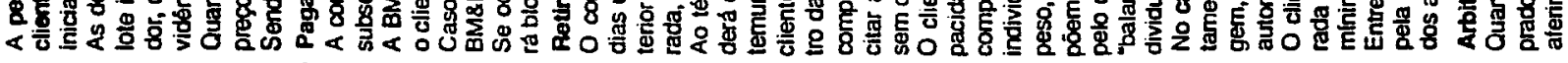




\section{APÊNDICE 2}

Contrato futuro cambial de boi gordo com as alterações efetuadas em fevereiro de 1992 

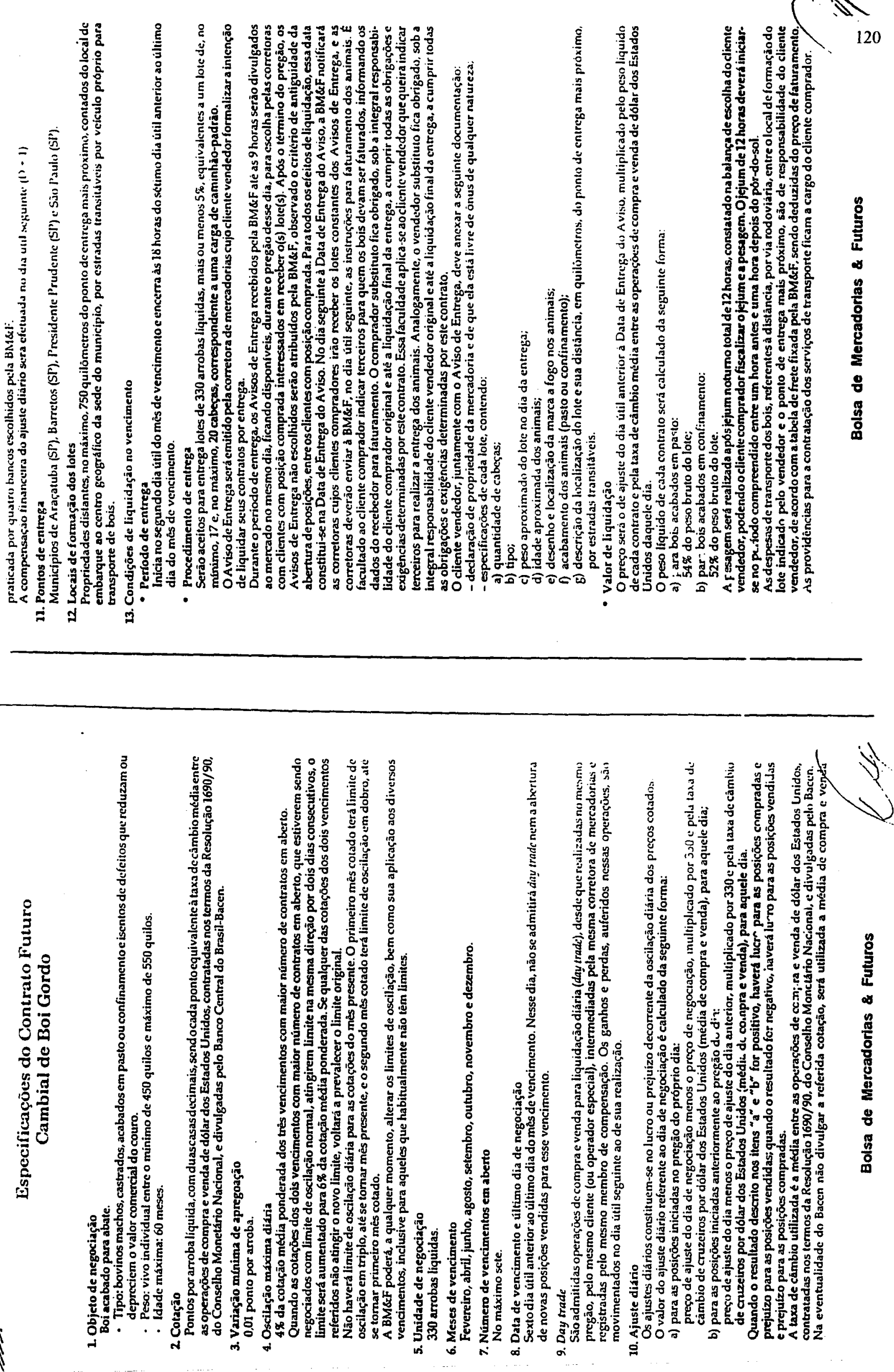


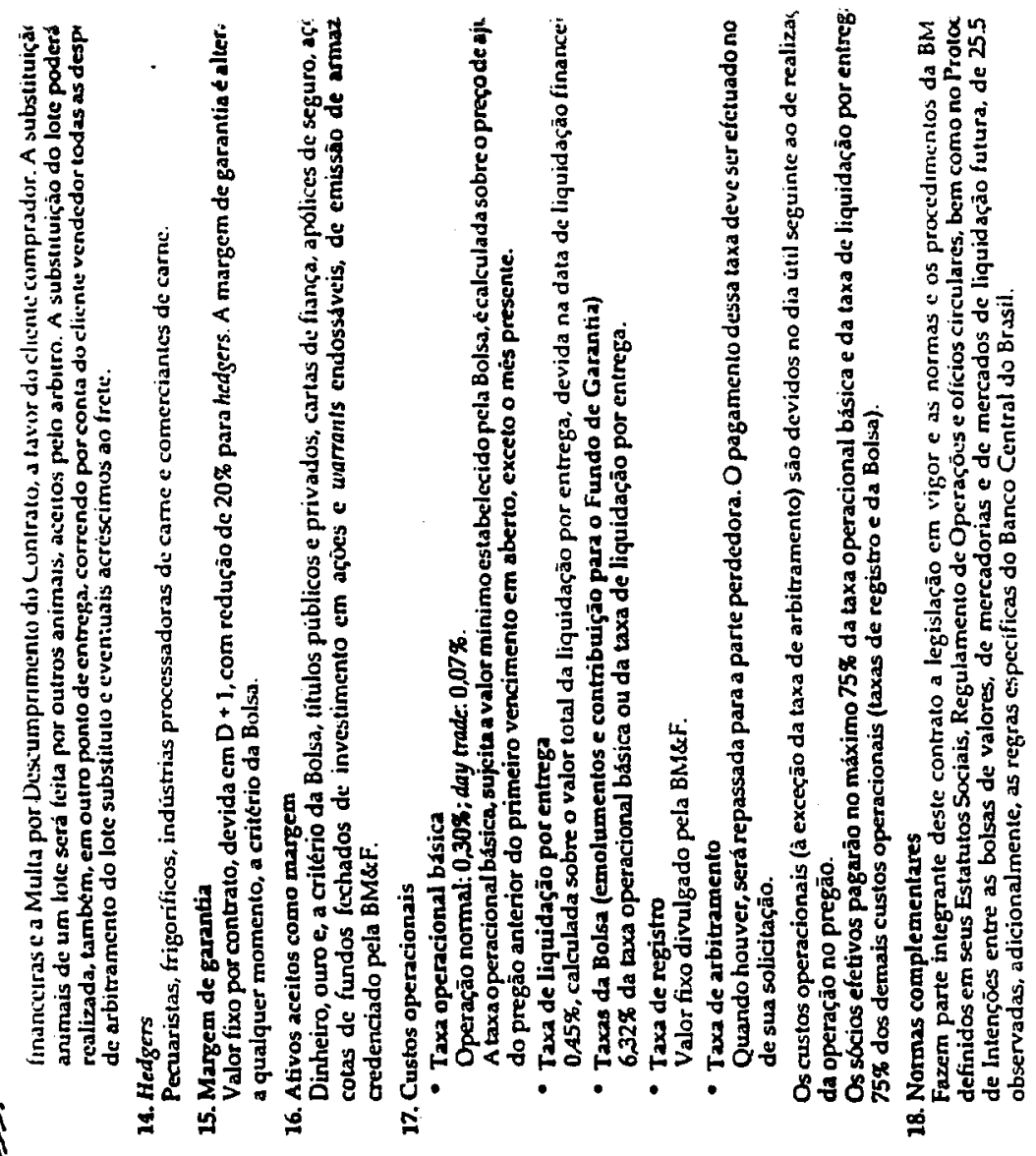
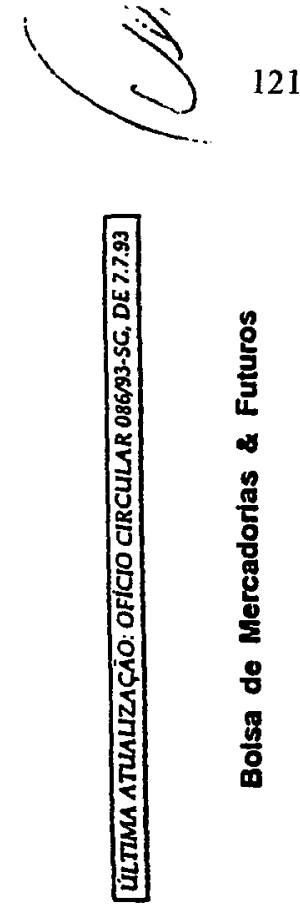



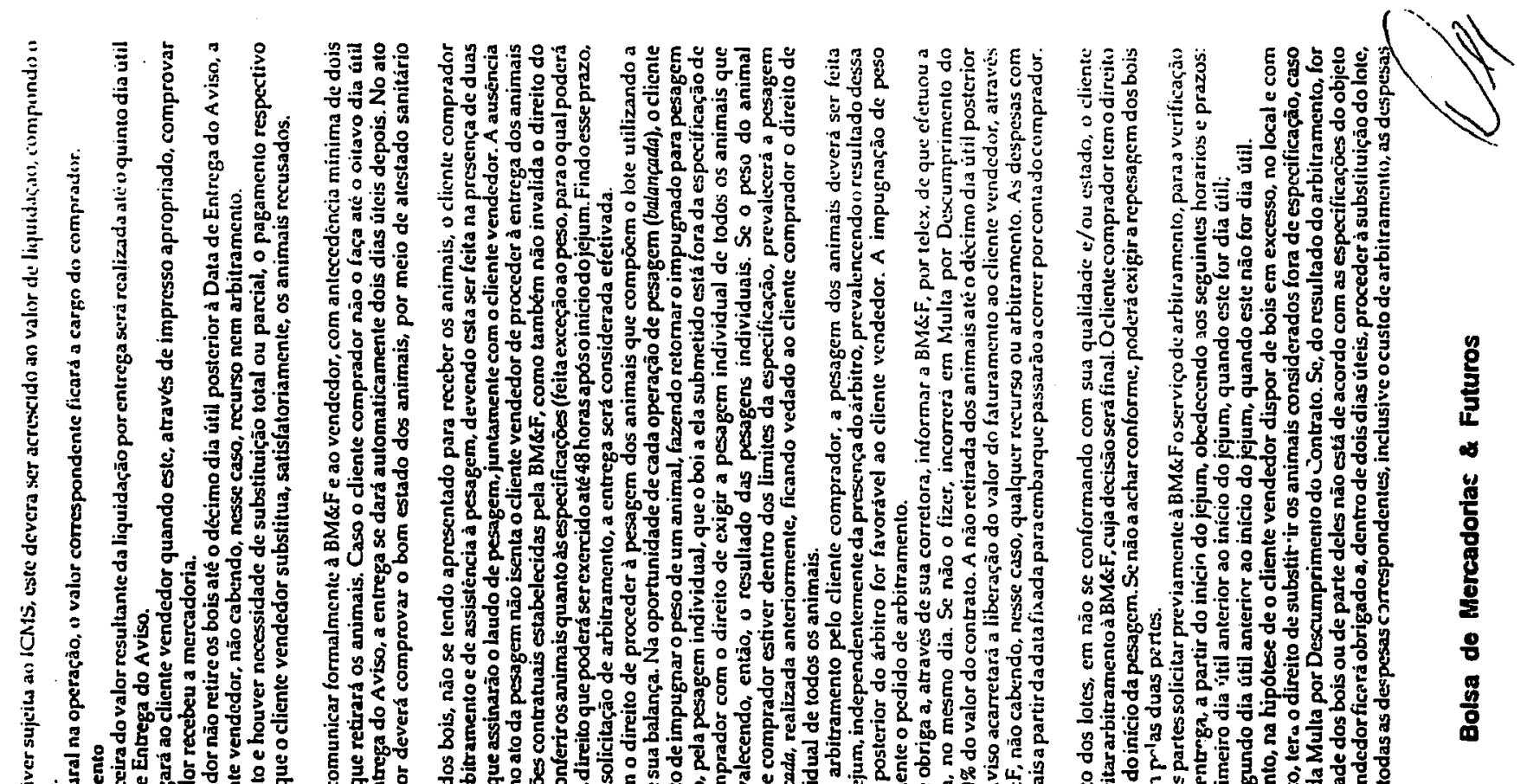
产

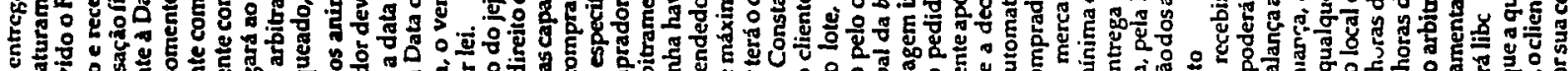

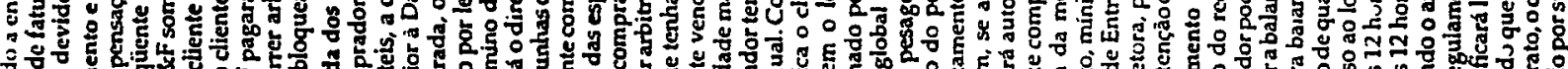

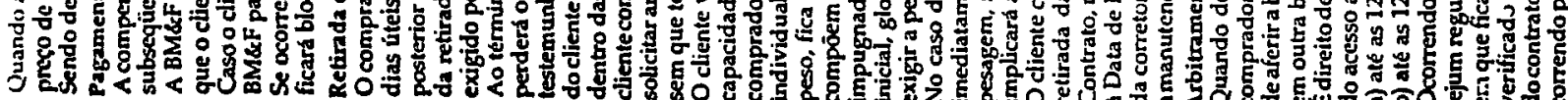




\section{APÊNDICE 3}

Contrato futuro cambial de boi gordo, com as alterações efetuadas em maio de 1994 


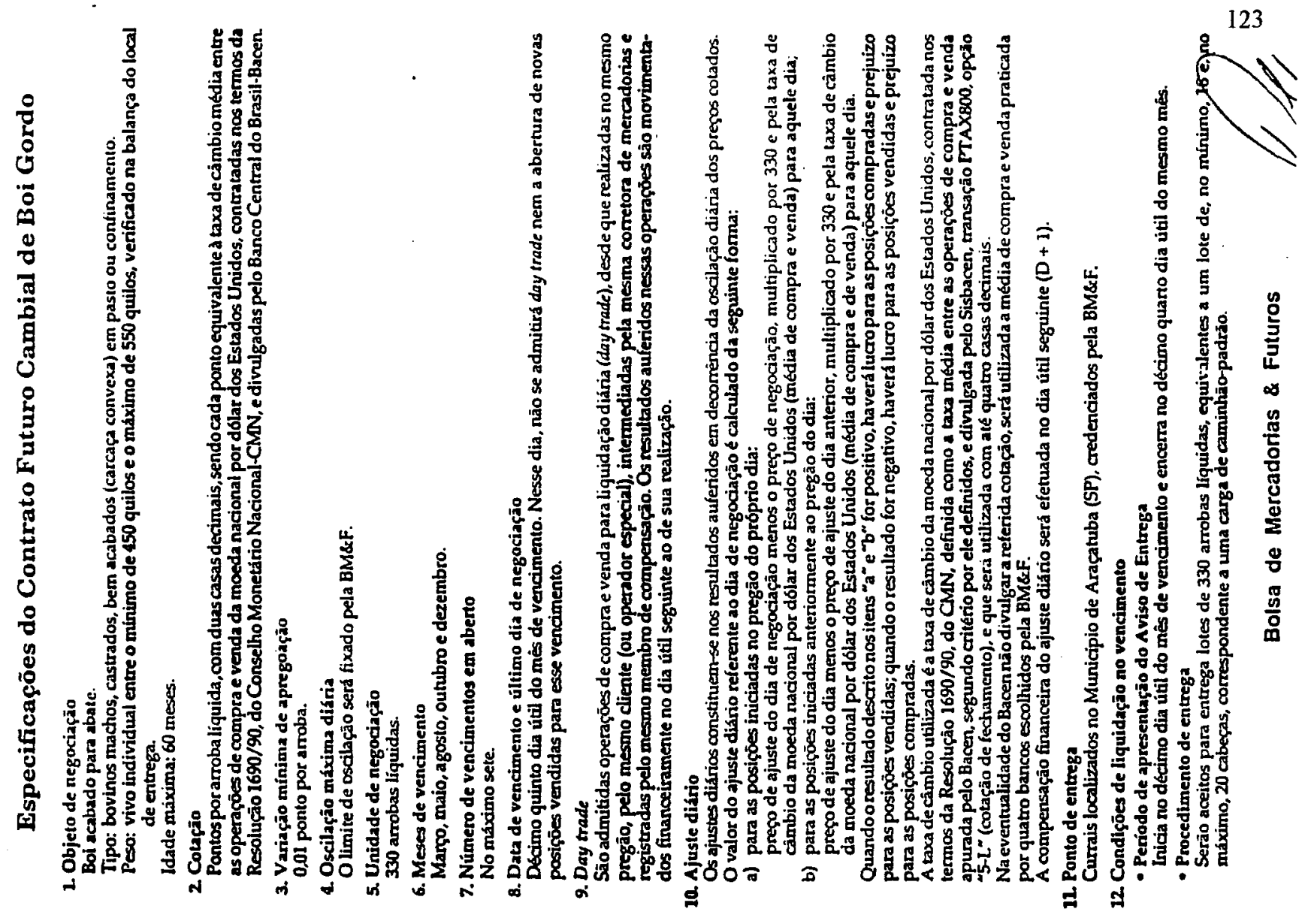

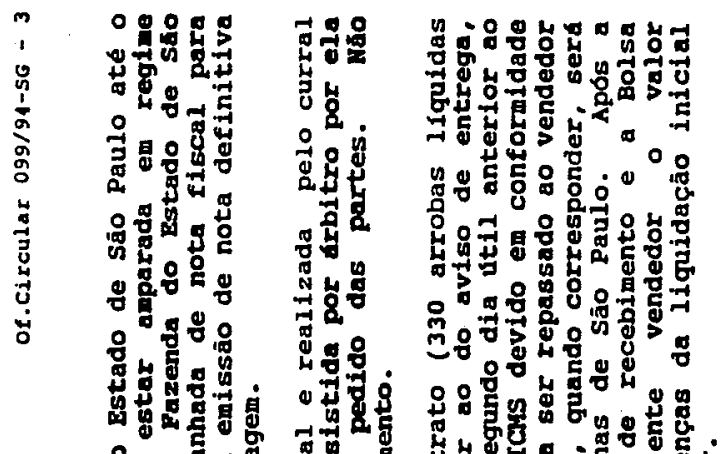

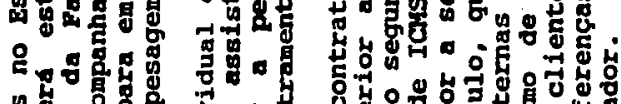

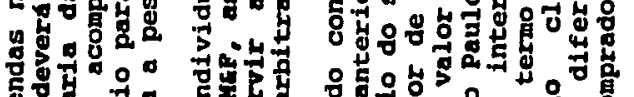

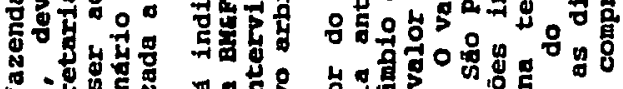

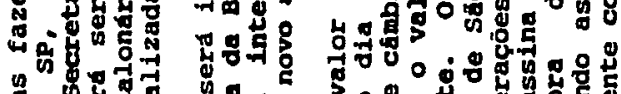
品

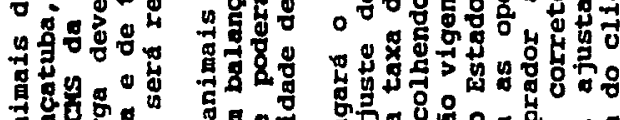

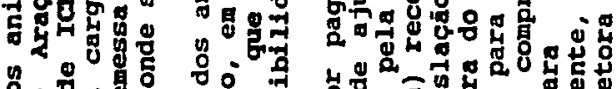

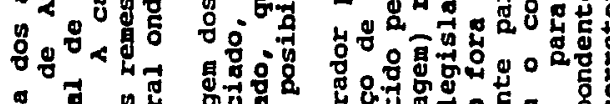

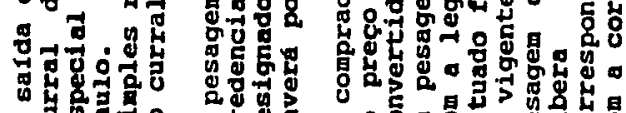

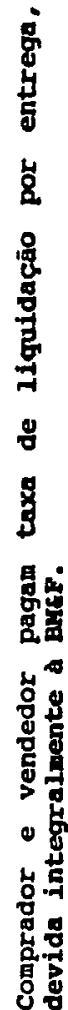

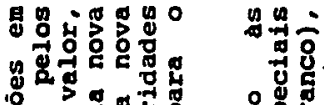

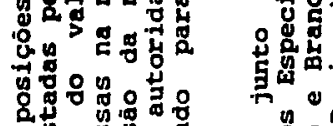

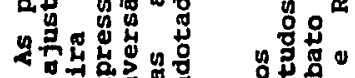

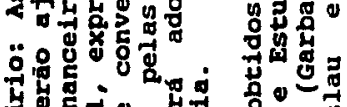

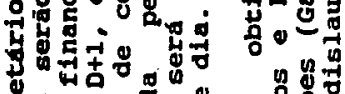

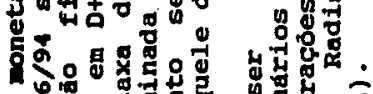

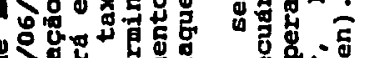

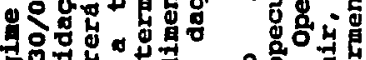

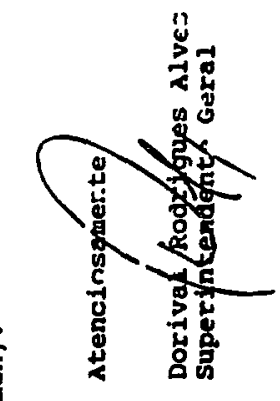

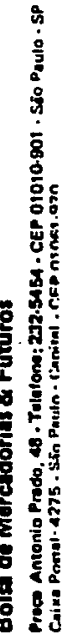

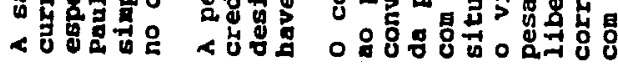

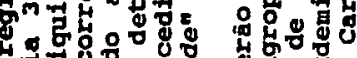

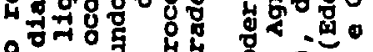

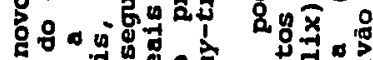

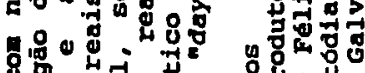

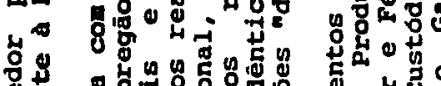

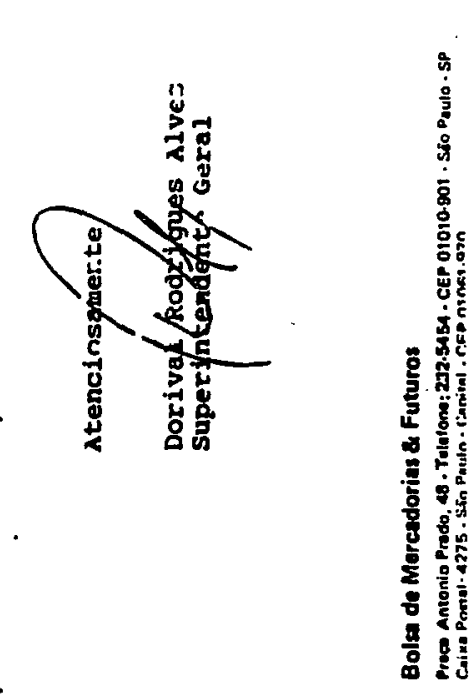

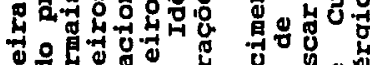

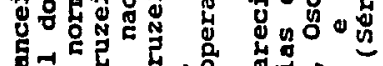

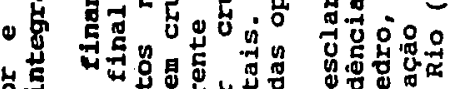

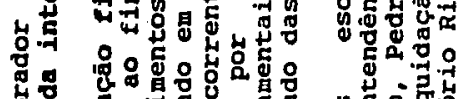

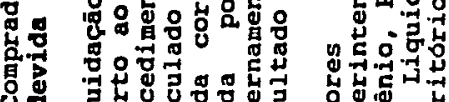

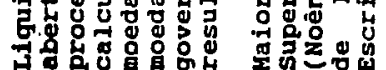



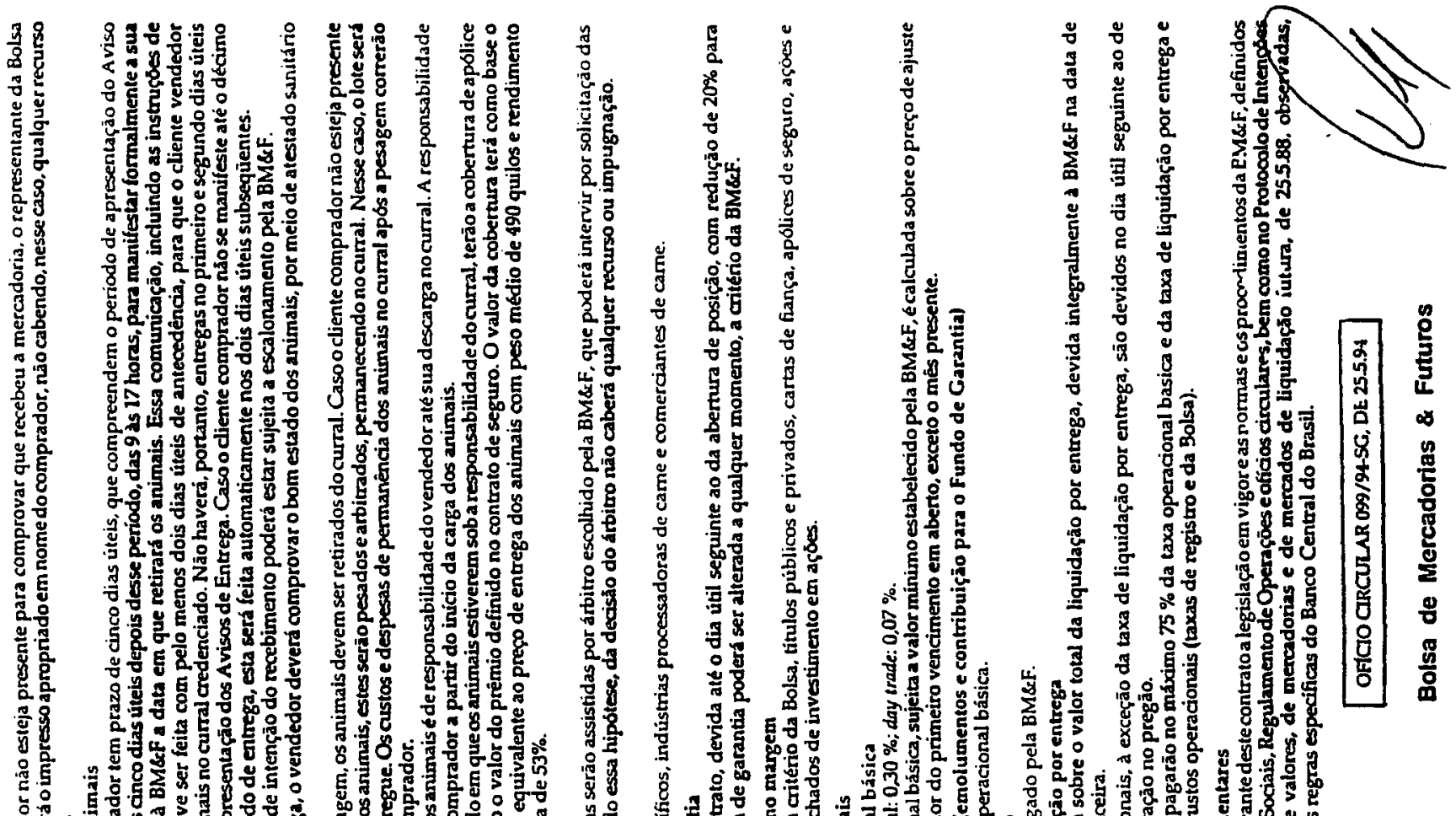

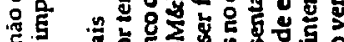

을

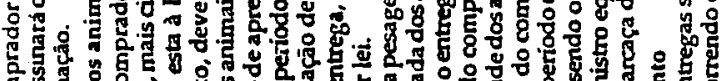

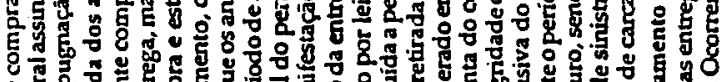

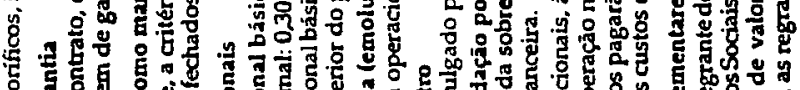

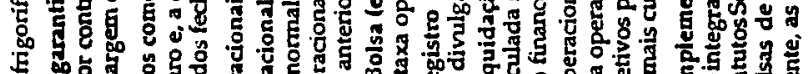
E

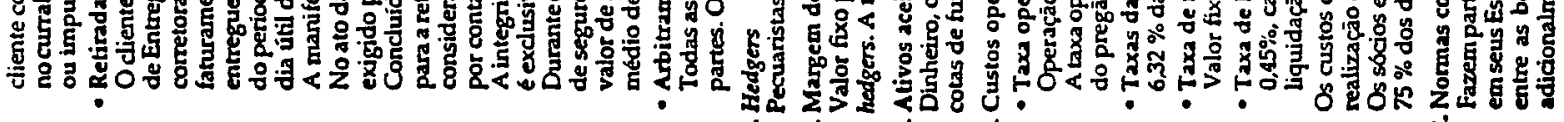

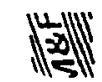

$$
\dot{\mathrm{g}} \mathrm{g} \text {. }
$$

\section{Ind

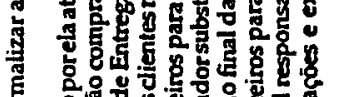

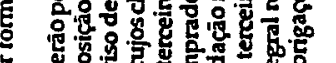

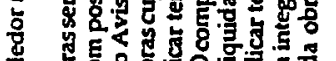 \\ 造

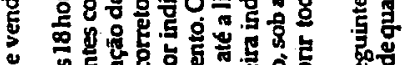

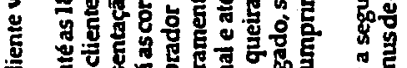

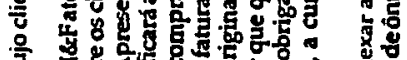

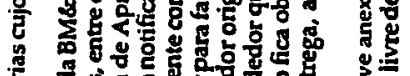 \\ 宽

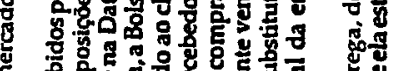 \\ ह \\ 范

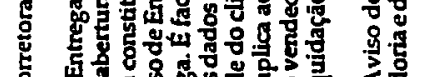

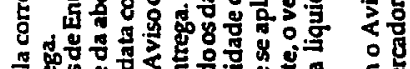

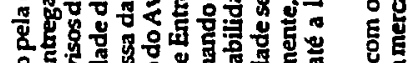

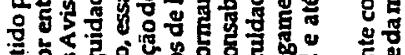

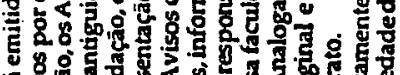

\% 象

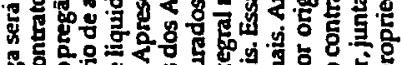

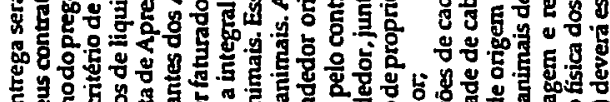

-

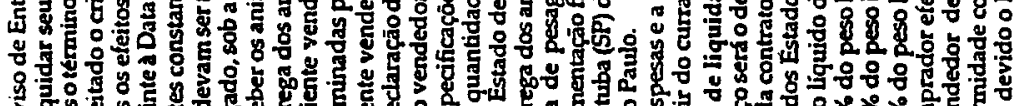

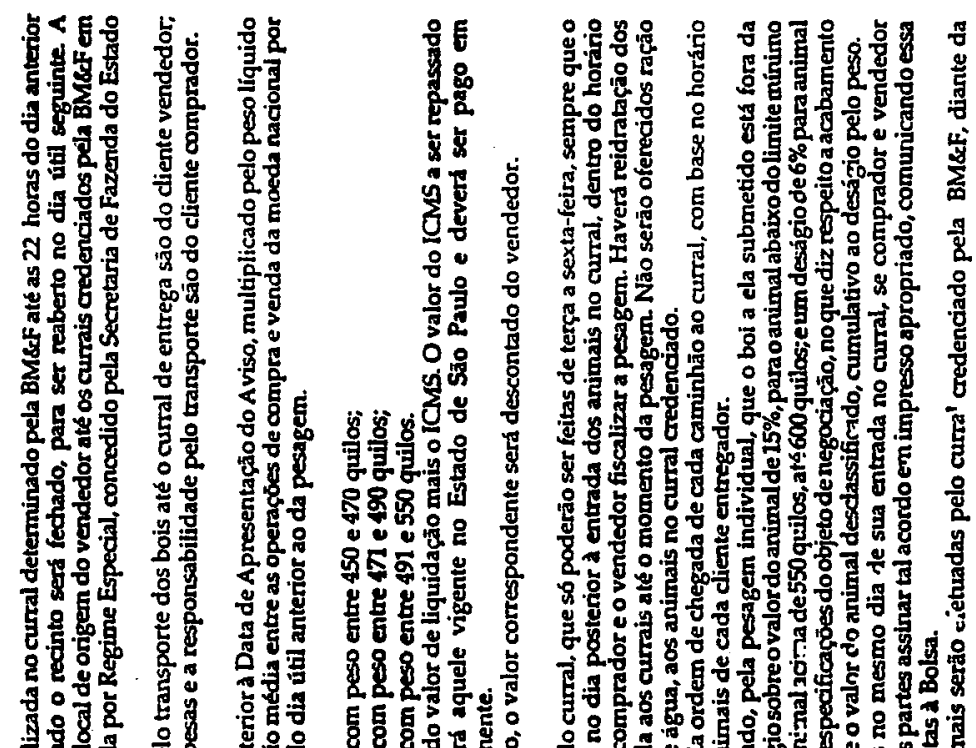
象:

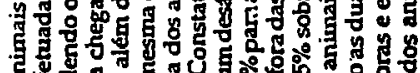

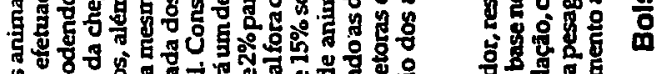

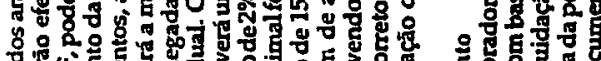

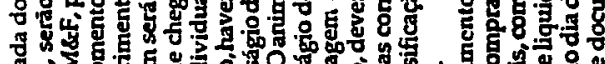

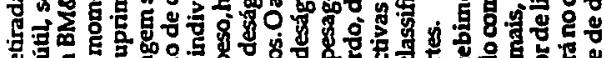

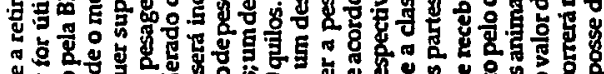

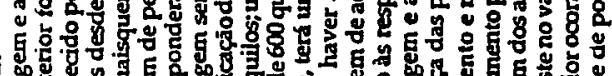
3
0 


\section{APÊNDICE 4}

Contrato futuro cambial de boi gordo, com as alterações efetuadas em dezembro de 1994 

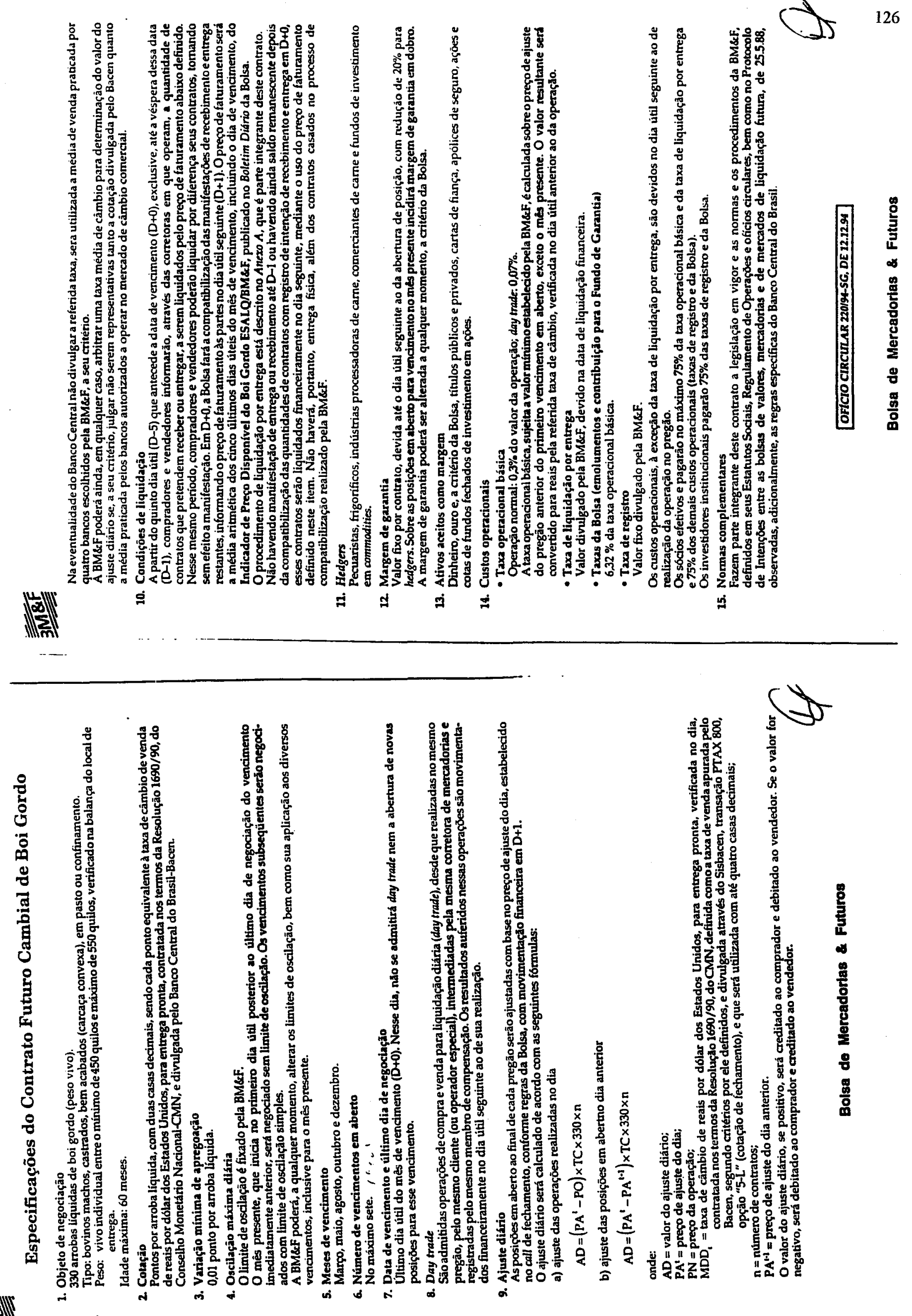


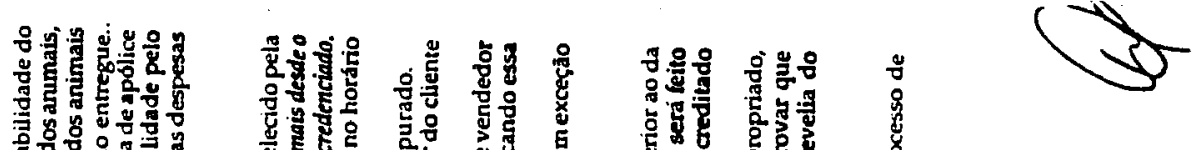

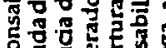

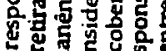

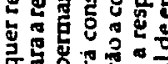

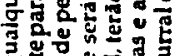

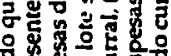

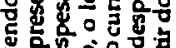

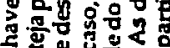

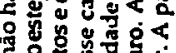

क्ष

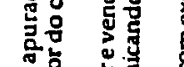

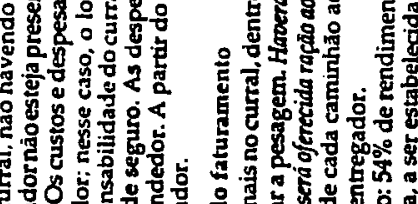

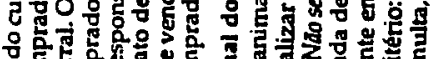

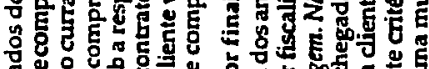

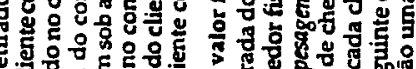

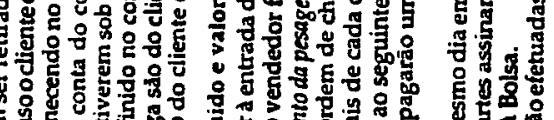

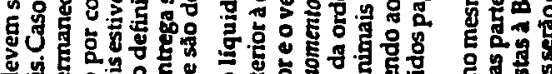

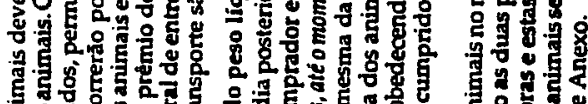

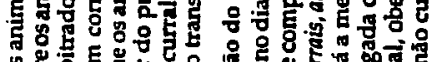

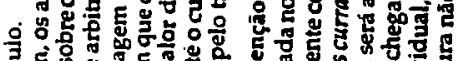

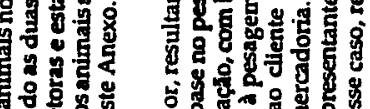

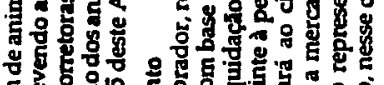

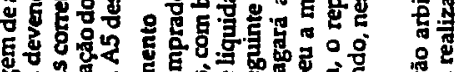

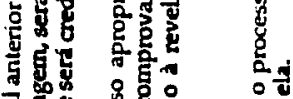

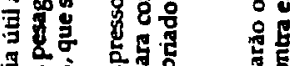

तु

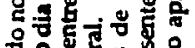

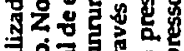

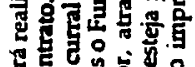

岛

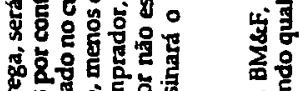

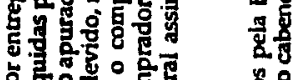

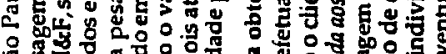

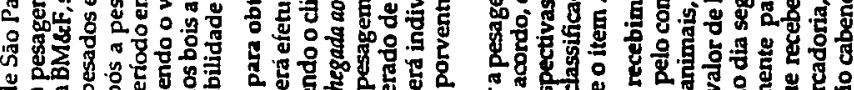

总

บั

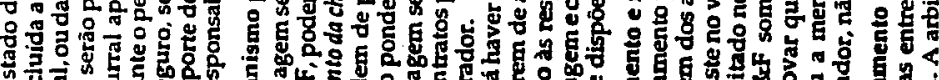

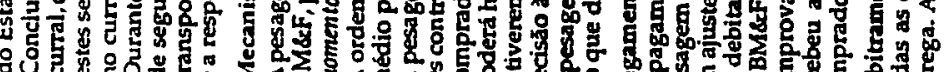

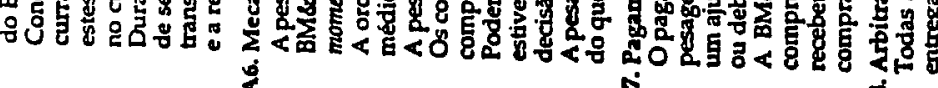

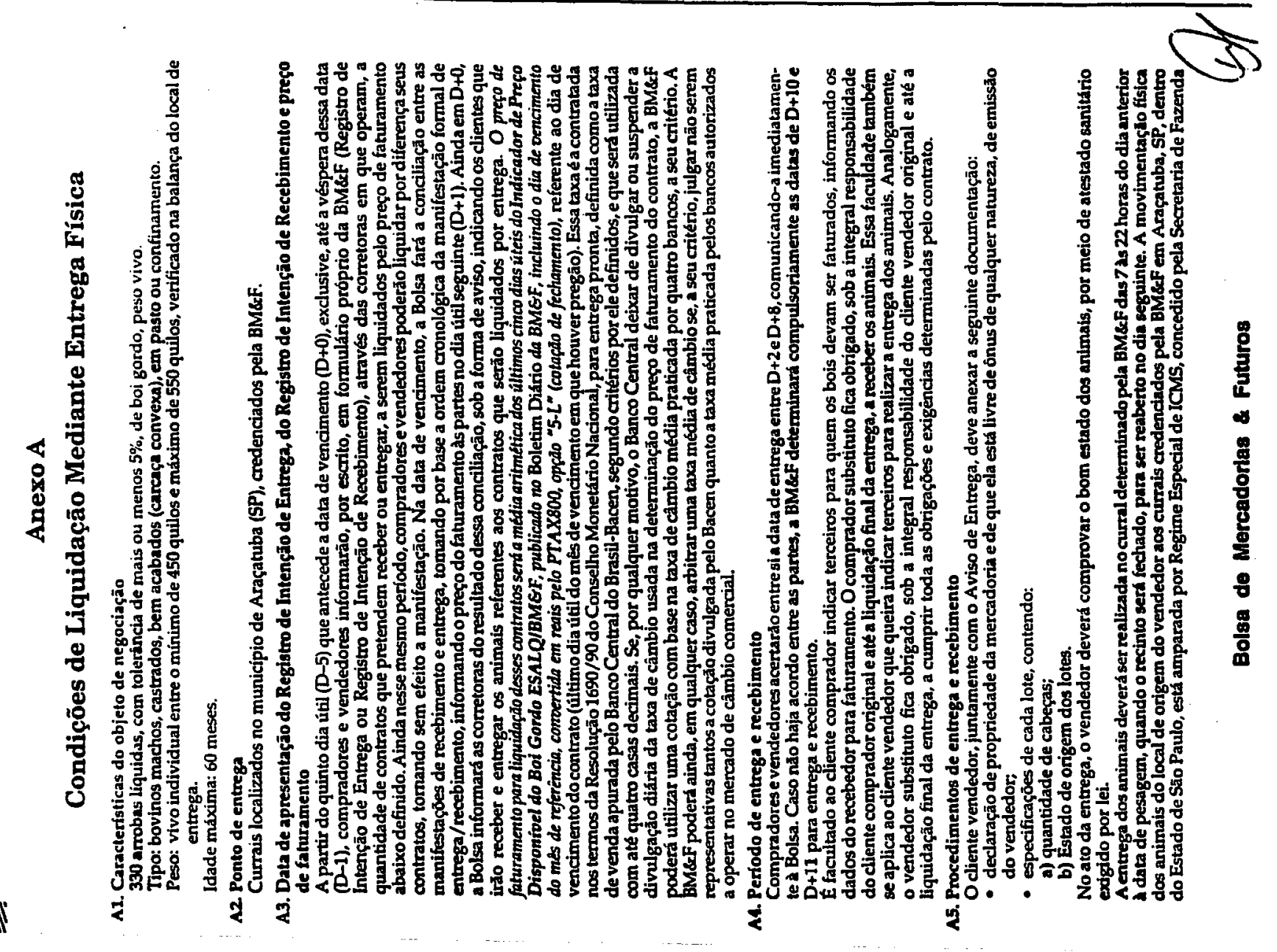




\section{APÊNDICE 5}

Esquema representando a utilização das observações da base na semana de vencimento do contrato futuro 
A base foi calculada na semana de vencimento de cada contrato, para machos e fêmeas em cada uma das 9 regiões. Então, a cada contrato corresponde uma base, de forma que no período anterior à introdução da liquidação financeira dispõem-se de 4 observações da base para o cálculo de sua variância e no período posterior à ela dispõem-se de 12 observações para este cálculo. Então, o esquema do cálculo das variâncias, antes e depois da introdução da liquidação financeira, para machos e fêmeas em cada região é apresentado a seguir.

\section{MACHOS}

Antes (4 contratos)

$\mathrm{s}^{2}$ antes $\left\{\begin{array}{l}\text { Out } / 94 \\ \mathrm{Dez} / 94 \\ \mathrm{Mar} / 95 \\ \mathrm{Mai} / 95\end{array} \quad \mathrm{~s}^{2}\right.$ depois $\left\{\begin{array}{l}\text { Ago } / 95 \\ \text { Out } / 95 \\ \mathrm{Dez} / 95 \\ \mathrm{Fev} / 96 \\ \mathrm{Abr} / 96 \\ \mathrm{Jun} / 96 \\ \mathrm{Ago} / 96 \\ \mathrm{Set} / 96 \\ \text { Out } / 96 \\ \mathrm{Nov} / 96 \\ \mathrm{Dez} / 96 \\ \mathrm{Fev} / 97\end{array}\right.$

Desta forma, a cada região corresponde uma variância da base antes e outra depois da introdução da liquidação financeira para machos. Uma vez que 9 regiōes são consideradas no estudo, existem 18 observações de variâncias da base para machos. 


\section{FÊMEAS}

Antes (4 contratos)

$\mathrm{s}^{2}$ antes $\left\{\begin{array}{l}\text { Out } / 94 \\ D e z / 94 \\ \text { Mar } / 95 \\ \text { Mai / } 95\end{array}\right.$
Depois (12 contratos)

$\sigma^{2}$ depois $\left\{\begin{array}{l}\text { Ago / } 95 \\ \text { Out } / 95 \\ \mathrm{Dez} / 95 \\ \mathrm{Fev} / 96 \\ \mathrm{Abr} / 96 \\ \mathrm{Jun} / 96 \\ \mathrm{Ago} / 96 \\ \mathrm{Set} / 96 \\ \text { Out } / 96 \\ \mathrm{Nov} / 96 \\ \mathrm{Dez} / 96 \\ \mathrm{Fev} / 97\end{array}\right.$

Da mesma forma, a cada região corresponde uma observação de variância da base antes e outra depois da introdução da liquidação financeira para fêmeas. Assim, como 9 regiões são consideradas no estudo, existem também 18 variâncias da base para fêmeas.

Para estimar o modelo de regressão (15), foram utilizados os desvios padrões da base, calculados a partir das variâncias obtidas conforme o esquema acima. Então, estimou-se a regressão com 36 observações do desvio padrão da base (18 antes $\rightarrow 9$ para machos e 9 para fêmeas e 18 depois $\rightarrow 9$ para machos e 9 para fêmeas). 


\section{APÊNDICE 6}

Resultados dos testes para determinar a ordem do processo auto-regressivo das séries da base nos meses de vencimento dos contratos futuros e valor dos desvios padrões do resíduo das auto-regressões 
Tabela A1. Resultados dos testes para determinar a ordem do processo auto-regressivo das séries da base nos meses de vencimento dos contratos futuros e valor dos desvios padrões do residuo das auto-regressões para a região de Araçatuba.

\begin{tabular}{lccccc} 
& \multicolumn{4}{c}{ Araçatuba } \\
\cline { 2 - 5 } & \multicolumn{3}{c}{ Machos } & \multicolumn{2}{c}{ Fêmeas } \\
\hline $\begin{array}{c}\text { Mês de vencimento } \\
\text { do contrato ao qual } \\
\text { se refere a série da } \\
\text { base }\end{array}$ & $\begin{array}{c}\text { Ordem do processo } \\
\text { auto-regressivo da } \\
\text { base }\end{array}$ & $\begin{array}{c}\text { Desvio padrão da } \\
\text { auto-regressão da } \\
\text { série da base no } \\
\text { mês de vencimento }\end{array}$ & $\begin{array}{c}\text { Ordem do processo } \\
\text { auto-regressivo da } \\
\text { base }\end{array}$ & $\begin{array}{c}\text { Desvio padrão da } \\
\text { auto-regressão da } \\
\text { série da base no } \\
\text { mês de vencimento }\end{array}$ \\
\hline OUTUBRO/94 & 1 & 1,0195 & 1 & 1,0384 \\
DEZEMBRO/94 & 5 & 0,9336 & 5 & 1,3543 \\
MARÇO/95 & 5 & 0,1043 & 5 & 0,2473 \\
MAIO/95 & 3 & 0,2326 & 2 & 0,3450 \\
AGOSTO/95 & 2 & 0,2320 & 1 & 0,2789 \\
OUTUBRO/95 & 3 & 0,1880 & 1 & 0,1985 \\
DEZEMBRO/95 & 5 & 0,1398 & 1 & 0,2297 \\
FEVEREIRO/96 & 1 & 0,1204 & 1 & 0,1499 \\
ABRIL/96 & 2 & 0,2378 & 1 & 0,2928 \\
JUNHO/96 & 1 & 0,1096 & 3 & 0,1518 \\
AGOSTO/96 & 1 & 0,2060 & 5 & 0,1651 \\
SETEMBRO/96 & 2 & 0,1595 & 1 & 0,2985 \\
OUTUBRO/96 & 1 & 0,2325 & 1 & 0,2187 \\
NOVEMBRO/96 & 3 & 0,1308 & 2 & 0,2920 \\
DEZEMBRO/96 & 1 & 0,1646 & 1 & 0,1781 \\
FEVEREIRO/97 & 1 & 0,1797 & 4 & 0,2393 \\
\hline
\end{tabular}

Tabela A2. Resultados dos testes para determinar a ordem do processo auto-regressivo das séries da base nos meses de vencimento dos contratos futuros e valor dos desvios padrões do resíduo das auto-regressões para a região de Bauru/Marília.

\begin{tabular}{lcccc} 
& \multicolumn{4}{c}{ Bauru/Marilia } \\
\cline { 2 - 5 } & \multicolumn{3}{c}{ Machos } & \multicolumn{2}{c}{ Fêmeas } \\
\hline $\begin{array}{c}\text { Mês de vencimento } \\
\text { do contrato ao qual } \\
\text { se refere a série da } \\
\text { base }\end{array}$ & $\begin{array}{c}\text { Ordem do processo } \\
\text { auto-regressivo da } \\
\text { base }\end{array}$ & $\begin{array}{c}\text { Desvio padrão da } \\
\text { auto-regressão da } \\
\text { série da base no } \\
\text { mês de vencimento }\end{array}$ & $\begin{array}{c}\text { Ordem do processo } \\
\text { auto-regressivo da } \\
\text { base }\end{array}$ & $\begin{array}{c}\text { Desvio padrão da } \\
\text { auto-regressão da } \\
\text { série da base no } \\
\text { mês de vencimento }\end{array}$ \\
\hline OUTUBRO/94 & 4 & 0,8649 & 1 & 0,8521 \\
DEZEMBRO/94 & 5 & 1,0458 & 1 & 1,1975 \\
MARÇO/95 & 5 & 0,3032 & 5 & 0,5250 \\
MAIO/95 & 1 & 0,2997 & 5 & 0,0931 \\
AGOSTO/95 & 1 & 0,2700 & 3 & 0,2368 \\
OUTUBRO/95 & 2 & 0,2181 & 4 & 0,1948 \\
DEZEMBRO/95 & 1 & 0,3721 & 4 & 0,2417 \\
FEVEREIRO/96 & 3 & 0,0928 & 1 & 0,1906 \\
ABRIL/96 & 3 & 0,2023 & 1 & 0,2094 \\
JUNHO/96 & 1 & 0,0949 & 3 & 0,1186 \\
AGOSTO/96 & 1 & 0,1217 & 2 & 0,1202 \\
SETEMBRO/96 & 1 & 0,1920 & 1 & 0,2693 \\
OUTUBRO/96 & 3 & 0,1945 & 1 & 0,2195 \\
NOVEMBRO/96 & 1 & 0,2321 & 4 & 0,2865 \\
DEZEMBRO/96 & 1 & 0,1507 & 1 & 0,1413 \\
FEVEREIRO/97 & 1 & 0,1577 & 4 & 0,1778 \\
\hline
\end{tabular}


Tabela A3. Resultados dos testes para determinar a ordem do processo auto-regressivo das séries da base nos meses de vencimento dos contratos futuros e valor dos desvios padrões do residuo das auto-regressões para a região de Barretos/São José do Rio Preto.

\begin{tabular}{lcccc} 
& \multicolumn{4}{c}{ Barretos/São José do Rio Preto } \\
\cline { 2 - 5 } & \multicolumn{3}{c}{ Machos } & \multicolumn{2}{c}{ Fêmeas } \\
\hline $\begin{array}{c}\text { Mês de vencimento } \\
\text { do contrato ao qual } \\
\text { se refere a série da } \\
\text { base }\end{array}$ & $\begin{array}{c}\text { Ordem do processo } \\
\text { auto-regressivo da } \\
\text { base }\end{array}$ & $\begin{array}{c}\text { Desvio padrão da } \\
\text { auto-regressão da } \\
\text { série da base no } \\
\text { mês de vencimento }\end{array}$ & $\begin{array}{c}\text { Ordem do processo } \\
\text { auto-regressivo da } \\
\text { base }\end{array}$ & $\begin{array}{c}\text { Desvio padrão da } \\
\text { auto-regressão da } \\
\text { série da base no } \\
\text { mês de vencimento }\end{array}$ \\
\hline OUTUBRO/94 & 1 & 1,0431 & 1 & 1,0280 \\
DEZEMBRO/94 & 5 & 1,1069 & 5 & 1,3878 \\
MARÇO/95 & 5 & 0,3518 & 5 & 0,3008 \\
MAIO/95 & 1 & 0,3824 & 2 & 0,3096 \\
AGOSTO/95 & 2 & 0,2506 & 1 & 0,2923 \\
OUTUBRO/95 & 3 & 0,2695 & 1 & 0,2857 \\
DEZEMBRO/95 & 1 & 0,2483 & 3 & 0,1229 \\
FEVEREIRO/96 & 1 & 0,1189 & 2 & 0,2044 \\
ABRIL/96 & 2 & 0,2655 & 4 & 0,2335 \\
JUNHO/96 & 5 & 0,0502 & 1 & 0,1208 \\
AGOSTO/96 & 1 & 0,1326 & 5 & 0,1066 \\
SETEMBRO/96 & 1 & 0,1734 & 1 & 0,2347 \\
OUTUBRO/96 & 1 & 0,1584 & 1 & 0,2071 \\
NOVEMBRO/96 & 1 & 0,1660 & 1 & 0,3625 \\
DEZEMBRO/96 & 1 & 0,1304 & 1 & 0,1272 \\
FEVEREIRO/97 & 5 & 0,1352 & 2 & 0,21001 \\
\hline
\end{tabular}

Tabela A4. Resultados dos testes para determinar a ordem do processo auto-regressivo das séries da base nos meses de vencimento dos contratos futuros e valor dos desvios padrões do resíduo das auto-regressões para a região de Presidente Prudente.

\begin{tabular}{lccccc} 
& \multicolumn{4}{c}{ Presidente Prudente } \\
\cline { 2 - 5 } & \multicolumn{3}{c}{ Machos } & \multicolumn{2}{c}{ Fêmeas } \\
\hline $\begin{array}{c}\text { Mês de vencimento } \\
\text { do contrato ao qual } \\
\text { se refere a série da } \\
\text { base }\end{array}$ & $\begin{array}{c}\text { Ordem do processo } \\
\text { auto-regressivo da } \\
\text { base }\end{array}$ & $\begin{array}{c}\text { Desvio padrão da } \\
\text { auto-regressão da } \\
\text { série da base no } \\
\text { mês de vencimento }\end{array}$ & $\begin{array}{c}\text { Ordem do processo } \\
\text { auto-regressivo da } \\
\text { base }\end{array}$ & $\begin{array}{c}\text { Desvio padrão da } \\
\text { auto-regressão da } \\
\text { série da base no } \\
\text { mês de vencimento }\end{array}$ \\
\hline OUTUBRO/94 & 1 & 0,9813 & 1 & 0,9661 \\
DEZEMBRO/94 & 1 & 1,2114 & 1 & 1,4006 \\
MARÇO/95 & 5 & 0,3066 & 5 & 0,3401 \\
MAIO/95 & 5 & 0,1394 & 5 & 0,0766 \\
AGOSTO/95 & 1 & 0,7020 & 5 & 0,2324 \\
OUTUBRO/95 & 1 & 0,2808 & 1 & 0,2283 \\
DEZEMBRO/95 & 1 & 0,2865 & 1 & 0,3526 \\
FEVEREIRO/96 & 1 & 0,1199 & 1 & 0,1494 \\
ABRIL/96 & 2 & 0,2804 & 1 & 0,5043 \\
JUNHO/96 & 1 & 0,1106 & 2 & 0,1386 \\
AGOSTO/96 & 4 & 0,1345 & 5 & 0,1699 \\
SETEMBRO/96 & 1 & 0,1763 & 1 & 0,1657 \\
OUTUBRO/96 & 5 & 0,0948 & 2 & 0,2445 \\
NOVEMBRO/96 & 1 & 0,1605 & 1 & 0,2703 \\
DEZEMBRO/96 & 1 & 0,1510 & 1 & 0,1395 \\
FEVEREIRO/97 & 4 & 0,1527 & 1 & 0,2086 \\
\hline
\end{tabular}


Tabela A5. Resultados dos testes para determinar a ordem do processo auto-regressivo das séries da base nos meses de vencimento dos contratos futuros e valor dos desvios padrões do residuo das auto-regressões para a região de Três Lagoas.

\begin{tabular}{lcccc} 
& \multicolumn{4}{c}{ Três Lagoas } \\
\cline { 2 - 6 } & \multicolumn{3}{c}{ Machos } & \multicolumn{2}{c}{ Fêmeas } \\
\hline $\begin{array}{c}\text { Mês de vencimento } \\
\text { do contrato ao qual } \\
\text { se refere a série da } \\
\text { base }\end{array}$ & $\begin{array}{c}\text { Ordem do processo } \\
\text { auto-regressivo da } \\
\text { base }\end{array}$ & $\begin{array}{c}\text { Desvio padrão da } \\
\text { auto-regressão da } \\
\text { série da base no } \\
\text { mês de vencimento }\end{array}$ & $\begin{array}{c}\text { Ordem do processo } \\
\text { auto-regressivo da } \\
\text { base }\end{array}$ & $\begin{array}{c}\text { Desvio padrão da } \\
\text { auto-regressão da } \\
\text { série da base no } \\
\text { mês de vencimento }\end{array}$ \\
\hline OUTUBRO/94 & 1 & 0,8868 & 1 & 1,0037 \\
DEZEMBRO/94 & 5 & 1,0449 & 5 & 0,9008 \\
MARÇO/95 & 5 & 0,1994 & 1 & 0,4823 \\
MAIO/95 & 1 & 0,2899 & 5 & 0,1459 \\
AGOSTO/95 & 1 & 0,2107 & 4 & 0,2222 \\
OUTUBRO/95 & 1 & 0,2001 & 1 & 0,4577 \\
DEZEMBRO/95 & 1 & 0,5391 & 1 & 0,3252 \\
FEVEREIRO/96 & 1 & 0,1061 & 1 & 0,1347 \\
ABRIL/96 & 1 & 0,2871 & 1 & 0,2377 \\
JUNHO/96 & 5 & 0,0967 & 5 & 0,2338 \\
AGOSTO/96 & 3 & 0,1355 & 1 & 0,3984 \\
SETEMBRO/96 & 4 & 0,1821 & 1 & 0,2762 \\
OUTUBRO/96 & 5 & 0,2102 & 3 & 0,3217 \\
NOVEMBRO/96 & 5 & 0,1695 & 3 & 0,4342 \\
DEZEMBRO/96 & 1 & 0,1658 & 1 & 0,3892 \\
FEVEREIRO/97 & 4 & 0,1826 & 1 & 0,3743 \\
\hline
\end{tabular}

Tabela A6. Resultados dos testes para determinar a ordem do processo auto-regressivo das séries da base nos meses de vencimento dos contratos futuros e valor dos desvios padrões do resíduo das auto-regressōes para a região de Triângulo Mineiro.

\begin{tabular}{lcccc} 
& \multicolumn{4}{c}{ Triângulo Mineiro } \\
\cline { 2 - 5 } & \multicolumn{3}{c}{ Machos } & \multicolumn{2}{c}{ Fêmeas } \\
\hline $\begin{array}{c}\text { Mês de vencimento } \\
\text { do contrato ao qual } \\
\text { se refere a série da } \\
\text { base }\end{array}$ & $\begin{array}{c}\text { Ordem do processo } \\
\text { auto-regressivo da } \\
\text { base }\end{array}$ & $\begin{array}{c}\text { Desvio padrão da } \\
\text { auto-regressão da } \\
\text { série da base no } \\
\text { mês de vencimento }\end{array}$ & $\begin{array}{c}\text { Ordem do processo } \\
\text { auto-regressivo da } \\
\text { base }\end{array}$ & $\begin{array}{c}\text { Desvio padrão da } \\
\text { auto-regressão da } \\
\text { série da base no } \\
\text { mês de vencimento }\end{array}$ \\
\hline OUTUBRO/94 & 1 & 1,0042 & 1 & 1,0846 \\
DEZEMBRO/94 & 4 & 1,1304 & 4 & 0,2533 \\
MARÇO/95 & 4 & 0,1717 & 4 & 0,5039 \\
MAIO/95 & 2 & 0,4148 & 5 & 0,1561 \\
AGOSTO/95 & 1 & 0,6271 & 1 & 0,2518 \\
OUTUBRO/95 & 3 & 0,2255 & 1 & 0,2106 \\
DEZEMBRO/95 & 2 & 0,2204 & 1 & 0,3215 \\
FEVEREIRO/96 & 1 & 0,0964 & 1 & 0,1096 \\
ABRIL/96 & 2 & 0,2881 & 2 & 0,2636 \\
JUNHO/96 & 5 & 0,0561 & 1 & 0,1427 \\
AGOSTO/96 & 1 & 0,1573 & 3 & 0,1628 \\
SETEMBRO/96 & 3 & 0,1584 & 1 & 0,1843 \\
OUTUBRO/96 & 1 & 0,1921 & 1 & 0,2043 \\
NOVEMBRO/96 & 5 & 0,1460 & 3 & 0,1963 \\
DEZEMBRO/96 & 5 & 0,0925 & 1 & 0,2104 \\
FEVEREIRO/97 & 1 & 0,1266 & 4 & 0,1691 \\
\hline
\end{tabular}


Tabela A7. Resultados dos testes para determinar a ordem do processo auto-regressivo das séries da base nos meses de vencimento dos contratos futuros e valor dos desvios padrões do residuo das auto-regressões para a região de Campo Grande.

\begin{tabular}{lccccc} 
& \multicolumn{5}{c}{ Campo Grande } \\
\cline { 2 - 5 } & \multicolumn{3}{c}{ Machos } & \multicolumn{2}{c}{ Fêmeas } \\
\hline $\begin{array}{c}\text { Mês de vencimento } \\
\text { do contrato ao qual } \\
\text { se refere a série da } \\
\text { base }\end{array}$ & $\begin{array}{c}\text { Ordem do processo } \\
\text { auto-regressivo da } \\
\text { base }\end{array}$ & $\begin{array}{c}\text { Desvio padrão da } \\
\text { auto-regressão da } \\
\text { série da base no } \\
\text { mês de vencimento }\end{array}$ & $\begin{array}{c}\text { Ordem do processo } \\
\text { auto-regressivo da } \\
\text { base }\end{array}$ & $\begin{array}{c}\text { Desvio padrão da } \\
\text { auto-regressão da } \\
\text { série da base no } \\
\text { mês de vencimento }\end{array}$ \\
\hline OUTUBRO/94 & 1 & 1,0751 & 1 & 1,1390 \\
DEZEMBRO/94 & 5 & 0,9139 & 5 & 1,3637 \\
MARÇO/95 & 5 & 0,1154 & 5 & 0,4978 \\
MAIO/95 & 1 & 0,2602 & 1 & 0,2474 \\
AGOSTO/95 & 2 & 0,2350 & 1 & 0,2938 \\
OUTUBRO/95 & 3 & 0,3078 & 1 & 0,2976 \\
DEZEMBRO/95 & 1 & 0,4301 & 1 & 0,3240 \\
FEVEREIRO/96 & 1 & 0,2048 & 1 & 0,2314 \\
ABRIL/96 & 2 & 0,2797 & 2 & 0,2185 \\
JUNHO/96 & 1 & 0,1050 & 5 & 0,1396 \\
AGOSTO/96 & 1 & 0,1729 & 5 & 0,0894 \\
SETEMBRO/96 & 1 & 0,1959 & 1 & 0,2310 \\
OUTUBRO/96 & 1 & 0,2433 & 1 & 0,2206 \\
NOVEMBRO/96 & 2 & 0,1554 & 3 & 0,1959 \\
DEZEMBRO/96 & 1 & 0,1577 & 1 & 0,1303 \\
FEVEREIRO/97 & 1 & 0,1789 & 1 & 0,2019 \\
\hline
\end{tabular}

Tabela A8. Resultados dos testes para determinar a ordem do processo auto-regressivo das séries da base nos meses de vencimento dos contratos futuros e valor dos desvios padrões do resíduo das auto-regressões para a região de Goiânia.

\begin{tabular}{|c|c|c|c|c|}
\hline \multirow[b]{3}{*}{$\begin{array}{c}\text { Mês de vencimento } \\
\text { do contrato ao qual } \\
\text { se refere a série da } \\
\text { base }\end{array}$} & \multicolumn{4}{|c|}{ Goiânia } \\
\hline & \multicolumn{2}{|c|}{ Machos } & \multicolumn{2}{|c|}{ Fêmeas } \\
\hline & $\begin{array}{c}\text { Ordem do processo } \\
\text { auto-regressivo da } \\
\text { base }\end{array}$ & $\begin{array}{l}\text { Desvio padrão da } \\
\text { auto-regressão da } \\
\text { série da base no } \\
\text { mês de vencimento }\end{array}$ & $\begin{array}{c}\text { Ordem do processo } \\
\text { auto-regressivo da } \\
\text { base }\end{array}$ & $\begin{array}{l}\text { Desvio padrão da } \\
\text { auto-regressão da } \\
\text { série da base no } \\
\text { mês de vencimento }\end{array}$ \\
\hline OUTUBRO/94 & 4 & 0,9453 & 1 & 1,0420 \\
\hline DEZEMBRO/94 & 5 & 1,2588 & 5 & 1,0534 \\
\hline MARÇO/95 & 5 & 0,1368 & 5 & 0,3020 \\
\hline MAIO/95 & 5 & 0,3984 & 1 & 0,3839 \\
\hline AGOSTO/95 & 1 & 0,2145 & 1 & 0,2906 \\
\hline OUTUBRO/95 & 1 & 0,2080 & 1 & 0,2634 \\
\hline DEZEMBRO/95 & 1 & 0,3237 & 1 & 0,3034 \\
\hline FEVEREIRO/96 & 1 & 0,2632 & 1 & 0,3114 \\
\hline ABRIL/96 & 2 & 0,2932 & 2 & 0,2235 \\
\hline JUNHO/96 & 5 & 0,1244 & 5 & 0,1123 \\
\hline AGOSTO/96 & 2 & 0,1652 & 4 & 0,1084 \\
\hline SETEMBRO/96 & 1 & 0,2714 & 1 & 0,1774 \\
\hline OUTUBRO/96 & 5 & 0.2046 & 5 & 0,2114 \\
\hline NOVEMBRO/96 & 4 & 0,1811 & 4 & 0,2094 \\
\hline DEZEMBRO/96 & 1 & 0,1591 & 1 & 0,1467 \\
\hline FEVEREIRO/97 & 1 & 0,1653 & 1 & 0,2255 \\
\hline
\end{tabular}


Tabela A9. Resultados dos testes para determinar a ordem do processo auto-regressivo das séries da base nos meses de vencimento dos contratos futuros e valor dos desvios padrões do resíduo das auto-regressões para a região de Norte do Paraná.

\begin{tabular}{lcccc} 
& \multicolumn{4}{c}{ Norte do Paraná } \\
\cline { 2 - 5 } & \multicolumn{3}{c}{ Machos } & \multicolumn{2}{c}{ Fêmeas } \\
\hline $\begin{array}{c}\text { Mês de vencimento } \\
\text { do contrato ao qual } \\
\text { se refere a série da } \\
\text { base }\end{array}$ & $\begin{array}{c}\text { Ordem do processo } \\
\text { auto-regressivo da } \\
\text { base }\end{array}$ & $\begin{array}{c}\text { Desvio padrão da } \\
\text { auto-regressão da } \\
\text { série da base no } \\
\text { mês de vencimento }\end{array}$ & $\begin{array}{c}\text { Ordem do processo } \\
\text { auto-regressivo da } \\
\text { base }\end{array}$ & $\begin{array}{c}\text { Desvio padrão da } \\
\text { auto-regressão da } \\
\text { série da base no } \\
\text { mês de vencimento }\end{array}$ \\
\hline OUTUBRO/94 & 1 & 0,9670 & 1 & 0,9611 \\
DEZEMBRO/94 & 5 & 1,0543 & 5 & 0,7655 \\
MARÇO/95 & 4 & 0,3564 & 3 & 0,4828 \\
MAIO/95 & 4 & 0,3971 & 1 & 0,4718 \\
AGOSTO/95 & 4 & 0,5020 & 4 & 0,5825 \\
OUTUBRO/95 & 2 & 0,1940 & 1 & 0,2493 \\
DEZEMBRO/95 & 1 & 0,3243 & 4 & 0,2559 \\
FEVEREIRO/96 & 3 & 0,1296 & 1 & 0,2579 \\
ABRIL/96 & 2 & 0,2970 & 5 & 0,2095 \\
JUNHO/96 & 3 & 0,1195 & 1 & 0,1220 \\
AGOSTO/96 & 1 & 0,3063 & 1 & 0,2307 \\
SETEMBRO/96 & 3 & 0,2232 & 1 & 0,1715 \\
OUTUBRO/96 & 1 & 0,2840 & 3 & 0,2723 \\
NOVEMBRO/96 & 2 & 0,2750 & 5 & 0,2123 \\
DEZEMBRO/96 & 1 & 0,2580 & 2 & 0,1730 \\
FEVEREIRO/97 & 1 & 0,2285 & 1 & 0,2014 \\
\hline
\end{tabular}




\section{APÊNDICE 7}

Base na semana de vencimento dos contratos futuros, calculada a partir dos preços à vista do IEA/CATI 

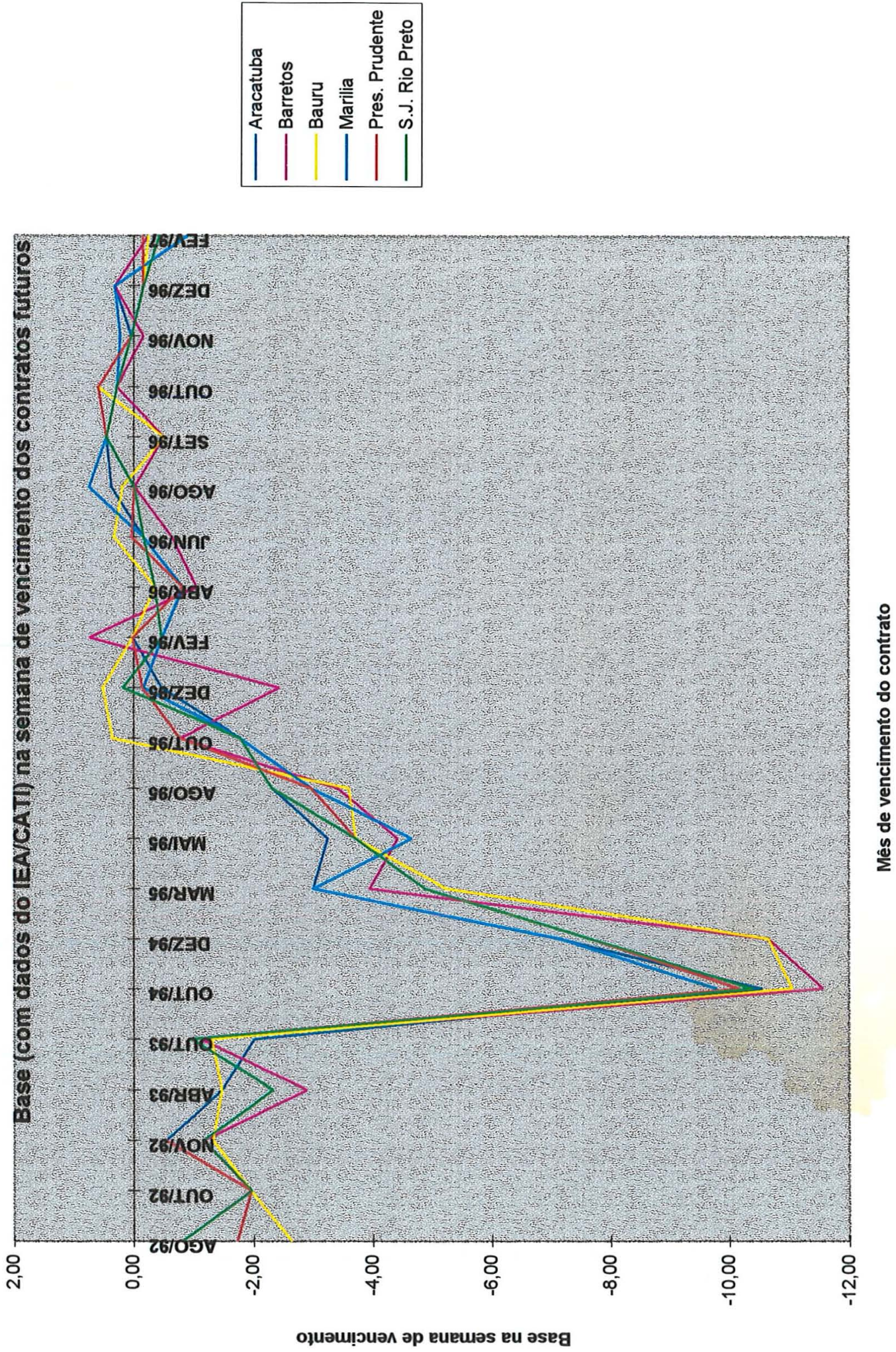


\section{APÊNDICE 8}

Resultados dos testes sobre igualdade de variâncias e dos testes sobre igualdade de médias da base na semana de vencimento do contrato, nos periodos anterior e posterior à introdução da liquidação financeira, utilizando os dados do IEA/CATI 
Tabela A10. Variâncias da base para machos na semana de vencimento do contrato, nos períodos anterior e posterior à introdução da liquidação financeira e resultados dos testes de Levene modificado para cada região.

\begin{tabular}{lccc}
\hline \multicolumn{1}{c}{ Regiões } & $\mathbf{s}^{2}$ antes & $\mathbf{s}^{2}$ depois & Valores de F \\
\hline Araçatuba & 10,47 & 0,82 & $2,69^{\star \star \star \star}$ \\
Bauru & 15,14 & 1,24 & $5,104^{\star \star \star}$ \\
Marília & 8,79 & 1,14 & $10,275^{\star}$ \\
Barretos & 16,58 & 1,42 & $4,155^{\star \star \star \star}$ \\
São José do Rio Preto & 11,13 & 0,69 & $8,430^{*}$ \\
Presidente Prudente & 11,84 & 0,86 & $9,562^{*}$ \\
* valor de F significativo a 1\%. & & \\
valor de F significativo a 5\%. & &
\end{tabular}

Tabela A11. Base média para machos na semana de vencimento dos contratos, antes e depois da introdução da liquidação financeira e resultados dos testes $t$.

\begin{tabular}{|c|c|c|c|}
\hline Regiões & $\bar{B}_{\text {antes }}$ & $\bar{B}_{\text {depois }}$ & Valores de $t$ \\
\hline Araçatuba & $-3,51$ & $-0,33$ & $-2,866^{\star \star \star}$ \\
\hline Bauru & $-4,37$ & $-0,24$ & $-3,093^{* *}$ \\
\hline Marília & $-6,15$ & $-0,44$ & 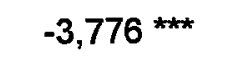 \\
\hline Barretos & $-4,28$ & $-0,66$ & $-2,586 * \star \star \star$ \\
\hline São José do Rio Preto & $-3,76$ & $-0,39$ & $-2,961 * \star \star$ \\
\hline Presidente Prudente & $-3,95$ & $-0,32$ & $-2,908^{* * *}$ \\
\hline
\end{tabular}

${ }^{54}$ Cochran, op. cit., p.97. 